\title{
EFEITO DO POTASSIO SOBRE A ATIVIDADE DE INVERTASES, TEORES DE ACÚCARES E COMPOSTOS NITROGENADOS EM CANA-DE-AÇÚCAR (Sacharum spp. var. NA56-79) CULTIVADA EM SOLUÇÃO NUTRITIVA
}

IRENICE MARIA SANTOS VIEIRA

Orientador: Prof. Dr. OTTO JESU CROCOMO

Dissertação apresentada à Escola Superior de Agricultura "Luiz de Queiroz", da Universidade de São Paulo, para obtenção do título de Mestre em Agronomia. ÁREA DE CONCENTRAÇAO: Solos e Nutrição de Plantas.

PIRACICABA

Estado de São Paulo - Brasil

Abril - 1983 
.i.

\author{
Aos meus filhinhos \\ Michella e Michell \\ DE DICO
}

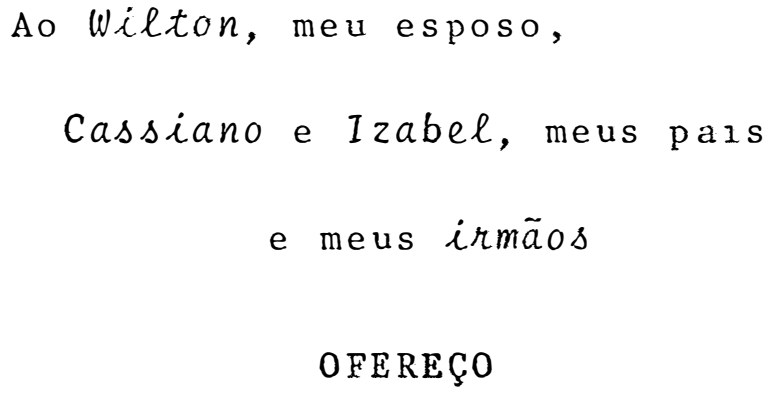


. ii.

\section{AGRADECIMENTOS}

- Ao Prof. Dr. Otto Jesu Crocomo, pela orientação, es tímulo e atenção de sempre, decisivos para a realiza ção deste trabalho.

- Ao Dr. Neftali Ochoa Alejo, pesquisador do CONACYT (México), pela amizade,valiosas sugestões e imensa colaboração.

- Aos Engenheiros Agronomos Lücio Salgado Vieira e Maria de Nuzaré Figueiredo Vieira (FCAP), Francisco A. F. MeZzo (ESALQ/USP) e AZcy Jaccoud (UFRRJ), pela ami zade, apoio e incentivo.

- Ao Engo Agro T. Yamada, diretor dos Institutos da Potassa (USA/SUIÇA) no Brasil, pelo suporte financeiro à pesquisa.

- Aos técnicos Carlos A. Dorelzi, Enio T. de oliveira e Sérgio C. Dorelzi pela assistência e em especial, ao Romeu Aparecido Rocha, pela colaboração nos traba1hos de laboratório.

- Aos meus colegas e amigos da Secão de. Bioquímica de Plantas e sefão de Fertilidade e Fertilizante do soIo do CENA, pela amizade e maravilhoso convivio.

- Ao Sr. Cleusval Bissi, pelo serviço de datilografia e Benedito H. Davanzo e Celso de Aguiar, pelos serviços de impressão.

- A Faculdade de Ciências Agrárias do Pará (FCAP), na pessoa do seu Diretor, Dr. Virgilio Libonatti, pela oportu nidade. 
- A Escola Superior de Agricultura "Luiz de Queiroz" (ESALQ) e Centro de Energia Nuclear na Agricultura (CENA), pelas facilidades:

- Ao Conselho Nacional de Desenvolvimento Cientifico e recnológico (CNPq), pela bolsa de estudo.

- A todos que direta ou indiretamente contribuiram para o desenvolvimento deste trabalho. 
.$i v$.

\section{I $N$ N}

Pàgina

RESUMO. . . . . . . . . . . . . . . . . . . vi vi

SUMMARY ... . . . . . . . . . . . . . . . viii

1. INTRODUÇÃO. . . . . . . . . . . . . . . . . 1

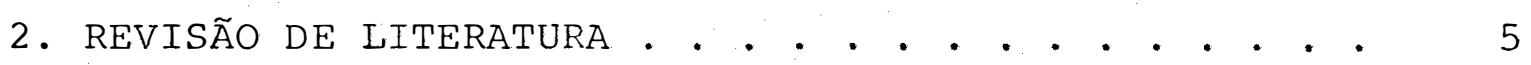

2.1. Função do ion $\mathrm{K}^{+}$no metabolismo da cana-de-açūcar 5

2.2. Consequências do suprimento inadequado de $\mathrm{K}^{+}$ no metabolismo da planta .. . . . . . . 12

2.3. Função das invertases no metabolismo de açücares em cana-de-açūcar. . . . . . . . 17

3. MATERIAL E MÉTODOS..................... 28

3.1. Cultivo das plantas e preparo do material. ... 28

3.2. Anālises quỉmicas... . . . . . . . 32

3.2.'. Determinação de carboidratos. . . . . 32

3.2.1.1. Açúcares redutores (AR), açūca res redutores totais (ART) e sacarose........ . 32

3.2.1.1.a) Extração. ... . 32

$3.2 .1 .1 . b)$ Quantificação . . . 32

3.2.2. Determinação dos compostos nitrogenados 33

3.2.2.1. Proteina. . . . . . . 33

3.2.2.1.a) Extração. .... 33

3.2.2.1.b) Quantificação . . 34 
3.2.2.2. Nitrogênio solúvel em álcool.. 34 3.2.2.2.a) Extração. •. . . 34 $3.2 .2 .2 . b)$ Suantificação . . 34

3.2.2.3. Nitrogênio total. . . . . . 35 3.2.2.3.a) Extração. •. •. 35 $3.2 .2 .3 . b)$ Suantificação • • 35

3.2.3. Determinação do potāssio. . . . . . 36 3.2 .3 .1 . Extração. . ..... . 36 3.2.3.2. Quantificação...... . 36

3.3. Anālise enzimātica. . . . . . . . . . . 36

3.3.1.a) Preparação do extrato enzimātico. . . 36

3.3.1.b) Determinação da atividade enzimātica. $\quad 37$

4. RESUltados E Discussão. . • . . . . . . . . . . . 38

4.1. Interação "Potāssio/Crescimento/Atividade de In vertases". . . . . . . . . . . . . 38

4.2. Interą̧ão "Potássio/Acúmulo de Açúcares/Ativide de Invertases" . . . . . . . . . . 4 45

4.3. Interação "Potāssio/Compostos Nitrogenados/Ati vidade de Invertases". . . . . . . . . 55

4.4. Interação "Potāssio/Atividades de Invertases" 62

5. CONCLUSÕES. • • . . . . . . . . . . . . . . . . 70

6. Literatura CitadA . . . . . . . . . . . . . 72

7. TABElas . . . . . . . . . . . . . . . . . . . . . 88 
.$v i$.

EFEITO DO POTÁSSIO SOBRE A ATIVIDADE DE INVERTASES, TEORES DE ACOUCARES E COMPOSTOS NITROGENADOS EM CANA-DE-ACUCAR I Saccharum spp. var. NA56-79) CULTIVADA EM SOLUÇÃO NUTRITIVA

Irenice Maria Santos Vieira

Prof. Dr. Otto Jesu Crocomo

- Orientador -

$R E S \cup M O$

No presente trabalho foram $\epsilon$ studadas as interrelações entre desenvolvimento da cana-de-açūcar (Saccharum spp. var. NA56-79) e os teores de açúcares e compostos nitrogenados dando ênfase as enzimas invertases bem como suas atuações em função dos diferentes níveis de potássio. Para isso, plântulas obtidas da cultura de tecidos de cana-de-açūcar, foram cultivadas em solução nutritiva contendo níveis crescentes de potássio $(0,1,6$ e $12 \mathrm{mM})$, mantidas em casa de vegeta ção por um período de 60 dias e colhidas a cada 20 dias num total de três colheitas. Ensaio de crescimento, atividade de invertase ācida $\left(\mathrm{pH}^{5}, 5\right)$, invertase neutra $(\mathrm{pH} 7,1)$, conteū do de sacarose, açūcares redutores (AR), açúcares redutores to tais (ART), proteína, $N$-total e $\mathrm{N}-\alpha-\mathrm{NH}_{2}$ solūvel foram realiza dos na parte aérea,que foi dividida em três segmentos (superior, mēdio e inferior).

A adição de baixo nível de potássio à solução nutritiva, teve em efeito depressor sobre o crescimento das plantas, as quais atingiram um nivel ótimo de crescimento na concentração de $6,0 \mathrm{mM}$ de $\mathrm{k}^{+}$. Aumento nos teores de sacarose, açūcares redutores e açūcares redutores totais, ocorreu em to 
dos os segmentos das plantas crescendo em condições de deficiência; inversamente, uma redução nos teores desses açúcares ocorreu quando a concentração de potássio foi de $12 \mathrm{mM}$. As variações dos níveis de potássio não afetaram significativamen te a atividade de invertases que não apresentaram nas condições deste estudo, uma tendência bem definida; entretanto, na concentração mais baixa $\left(0,1 \mathrm{mM}\right.$ de $\left.\mathrm{K}^{+}\right)$a atividade das enzimas foi mais alta. Uma correlação inversa entre atividade de invertase e conteúdo de sacarose ocorreu em todos os segmentos independente do nỉvel de potássio que foi fornecido a solução nutritiva. No segmento inferior onde a atividade da enzima foi muito baixa, a sacarose,formou quase $80 \%$ de matéria seca. Por outro 1 ado, no segmento médio e no segmento superior onde a atividade da enzima foi mais elevada durante todo o experimento, não ocorreu acūmulo de quantidades apreciáveis de sacarose e

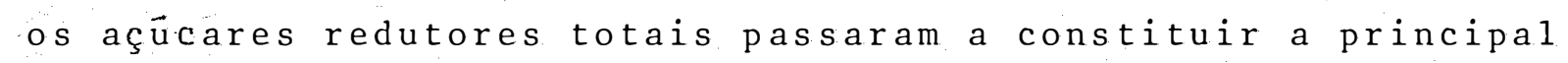
forma de armazenamento. Estes resultados sugerem que o principal fator que controla o nível de açücares na parte aérea da cana-de-açùcar é a atividade destas duas enzimas, que utilizam sacarose como substrato. Em todos os casos, a atividade da invertase ácida foi relativamente maior do que a invertase neutra, indicando que nas condições do experimento a invertase. ácida foi a enzima predominante.

No segmento superior, a redução do teor de proteỉnas e N-total induzida pelas variações da nutrição potässica, foram mais acentuadas em dose excessiva de potássio do que em condições de deficiência. As plantas deficientes acumularam $\mathrm{N}-\alpha-\mathrm{NH}_{2}$ solūvel como resultado de uma intensa redução na sintese de proteínas que por sua. vez pode ter determinado o maior acúmulo de açúcares redutores e a redução do crescimento. 
EFFECT OF POTASSIUM ON THE ACTIVITY OF INVERTASES, LEVEL OF SUGARS AND NITROGEN COMPOUNDS IN SUGARCANE (Saccharum spp. var. NA56-79) GROWN IN NUTRIENT SOLUTION

\author{
Irenice Maria Santos Vieira
}

\author{
Prof. Dr. Otto Jesu Crocomo \\ - Adviser -
}

$S U M M A * R \quad Y$

The present research work dealt with the interrelationship between the development of sugarcane (Saccharum spp. var. NA56-79) and level of sugars and nitrogen compounds, influenced by potassium nutrition, emphasizing the activity of the invertase enzymes. In order to reach this objective, seedlings obtained by tissue culture techniques were maintained in nutrient solution in the presence of the fol1owing potassium concentrations $(0.1,6.0$ e $12.0 \mathrm{mM})$ in grefnhouse during 60 days and a total of three harvests were made at 20 day intervals. Growth rate, acid $(\mathrm{pH} 5,5)$ and neutra1 ( $\mathrm{pH} 7,1)$ invertase activities, sucrose, reducing sugars (RS), total reducing sugars (TRS), protein, total-N and $\alpha-\mathrm{NH}_{2}-\mathrm{N}$ contents were determined in sugarcane shoots which were derived in three different segments: upper, intermediate and 1 ower.

Addition of low potassium concentration to the nutrient solution had an inhibitory effect on plant growth, which reached the highest levels of growth at the $6.0 \mathrm{~mm}$ concentration. Increase of the levels of sucrose, reducing sugars and total reducing sugars occurred in all plant segments 


\section{.$i x$}

growing under deficiency conditions; inversely, a reduction in the levels of these sugars occurred when the potassium concentration was $12 \mathrm{mM}$. Variation in potassium levels did not effect significantly invertase activity, which did not show a definite tendency; but, at lower concentrations ( 0.1 nM de $\mathrm{K}^{+}$) the activity of these enzymes was higher. An inverse correlation was found between invertase activity and sucrose leve1s in a11 plant segments, independent1y of the amount of potassium supplied to the nutrient solution. In the lower segment, were invertase activity was very low, sucrose accumulated up to about $80 \%$ of the total dry matter. On the other hand, in the intermediate and upper segments the enzyme remained high throughout the experiment, sucrose did not accumulated and total reducing sugars became the main form of stored sugar. These results suggest, therefore, that the main factors controlling sugar levels in sugarcane shoots is the relative activity of these two enzymes, both utilizing sucrose as substrate. In a 11 cases, the acid invertase activity was relatively higher than that of the neutral invertase, indicating that the acid invertase was the predominant enzyme under the present study conditions.

In the upper segment, the decrease in protein and tota1-N levels, induced by the variation in K-levels were much more accentuated in high-K plants than in the K-deficient plants. These plants however, accumulated soluble $\alpha-\mathrm{NH}_{2}-\mathrm{N}$, which is an indication of an intense decrease in protein synthesis which also determined a greater accumulation of reducing sugars and a decrease in the growth rate. 


\section{INTRODUÇÃO}

A localizáção do sítio específico de ação do potássio nas fases do metabolismo de açücares em plantas de ca na-de-açūcar, nos sucessivos estágios do desenvolvimento tem sido extensivamente investigado.

Como jā é conhecido, o potássio afeta direta ou indiretamente muitas, senão todas, as funções bioquímicas e fi siológicas da planta, sendo considerado o fator que mais contribui para o melhor crescimento e maior produção da cana-de-açúcar. A anālise bioquímica das partes constituintes das plantas, especialmente tecidos armazenadores de folha, bainha e colmo revelam elevada exigência de $K^{+}$pela cultura, mais do que o $N$, ou qualquer outro nutriente. Plantas adequadamente supridas com potássio segundo inumeros autores, acumulam gran des quantidades de carboidratos solúveis em seus tecidos de. armazenamento o que pode ser atribuído a elevada atividade fotossintetica de plantas bem supridas com esse nutriente.

Inümeras investigações conduzidas em solução nu tritiva, têm tentado, pelo controle da nutrição potássica,indu zir mudanças no conteūdo de açūcares em internödios de cana-de-açūcar, com o objetivo de determinar de que maneira elas estão correlacionadas com a atividade de enzimas responsáveis 
pela biossintese de açücares.

Os autores que estudam esta situação, têm verificado que a ausência de quạtidades significantes de sacarose, associada com a presença de altos teores de açūcares redutores correlacionam-se com a existência de elevados níveis de invertase àcida solūvel, muito ativa em tecidos de cana-de-açúcar durante o período de desenvolvimento. A atividade dessa enzima começa a desa parecer quando cessa a elongação celular, sendo substituída pela atividade de invertase neutra que aumenta durante a maturação.

As atividades de ambas as formas de invertase diferem em propriedades e localização celular, mas o modo como elas estão relacionadas ao metabolismo da planta e ao nível de potässio não está totalmente elucidado. De particular inte resse è a identificação de mudanças significantes no comporta mento de isoenzimas de invertases durante o período de transição de tecidos meristemáticos para tecidos adultos em internó dios de cana-de-açūcar.

Compàrativamente, a separação espacial de distintos níveis de desenvolvimento celular em internódios de cana-de-açūcar, tem se constituỉdo um excelente material para se estudar os efeitos dos elementos minerais em termos de atividade enzimātica.

Apesar da existência de trabalhos realizados com plantas de ervilha, aveia, tomate, cevada, mostrando a influência da atividade de invertases, sobre o acūmulo de açūa res, em diferentes regiões de crescimento da parte aérea, nos sucessivos estágios de desenvolvimento; poucos autores, tem estabelecido tal correlação com o potássio, sobretudo em plantas de cana-de-açūcar.

Entretanto, ainda que exista uma escassez de in 
formações sobre trabalhos desta natureza, muitos pesquisadores, tem demonstrado que o colmo de plantas jovens de cana-de-açücar é um material particularmente adequado para o estudo dos processos de transporte e armazenamento de assimilados. Além disso, considerando os processos bioquímicos que levam à prodü ção de açúcares, a produtividade de cana-de-açúcar pode ser descrita pelas relações "fonte-reservatório". Os tecidos verdes com a sua consequente capacidade de fotossíntese representam a "fonte", enquanto que, o "reservatório" é representado pelos órgãos da planta que se utilizam dos fotossintetados, pa ra o crescimento e metabolismo. O potássio nesse caso, parece funcionar como um agenterestimulador da fonte, isto é, do su primento de fotossintetados para os órgãos de armazenamento.

Ensaio com cana-de-açúcar conduzidos em vários laboratórios, utilizando ${ }^{14} \mathrm{CO}_{2}$, tem mostrado que a sacarose, é,entre outros, como glucose e frutose, o mais importante açúcar que se forma, constituindo cerca de 80 a $90 \%$ dos produtos fotossintetizados e que após sua biossintese na folha é transportada para o colmo onde é armazenado, a medida que a planta se desenvolve. Como todos os processos regulados metabolicamente, o transporte de açúcares através desse sistema "fonte-reservatório" envolve enzimas, possivelmente invertases as quais, via de regra, exigem potássio para sua atividade.

Assim, se tanto o potássio como invertases éstão distribuídos por todos os órgãos da pianta, se são inerentes às células em crescimento e se estão implicados na forma ção e acúmulo de carboidratos solúveis, é de se esperar que am bos sejam considerados fatores que limitam o crescimento e a produção da planta. Desde que o conhecimento desses fatores é um pré-requisito para melhor interpretação dos fenômenos bioquímicos que contribuem, em ūltima análise para maximizar o potencial de utilização de uma variedade, e desde que no 
estádio inicial do desenvolvimento as plantas possuem todas as informações necessárias para canalizar seu desenvolvimento até a formação da planta adulta; o estudo dos.segmentos das re giões de crescimento de parte aérea de cana-de-açūcar pode ser fonte de valiosas informações.

Pretendeu-se portanto, nesse trabalho, dar uma contribuição para se compreender o efeito do potássio sobre as interações entre a atividade de invertase ácida e invertase neu tra com o metabolismo de açücares e compostos nitrogenados, na parte aērea de cana-de-açūcar cultivada emsolução nutritiva. 


\section{REVISAOO DE LITERATURA}

2.1. Função do ĩon $\mathrm{K}^{+}$no metabolismo da cana-de-açūcar

Na cana-de-açūcar, como em todas as plantas superiores, o potássio tem muitas funções nos seus processos bioquímicos e fisiológicos, por isso seus efeitos sobre os processos metabōlicos relacionados ao desenvólvimento, não podem ser enumerados detalha damente, mas sim grupados de acordo com aqueles principais, que contribuem para produção final de açūcares, e que são: biossín tese, translocação e acümulo de sacarose nas células imaturas de armazenamento.

Existe um grande nümero de trabalhos que descrevem os efeitos do $\mathrm{K}^{+}$em muitos ou em quase todos os proces sos metabólicos da cana-de-açūcar, não estando claro porém, se os efeitos são de natureza direta ou se indireta (DILLEWIJN, 1952). Selecionando os dados de alguns autores pode-se distin guir vārios grupos principais: $\mathrm{O}^{+}$intervém na síntese de açucar e amido; na síntese de proteínas, principalmente nos teci dos meristemáticos; no aumento da clorofila bruta e conversão de energia nos cloropiastos, e na abertura e fechamento dos es tômatos: Essa ültima função possibilita a retenção de água e a manutenção do turgor celular; o que cria condições favoráveis para as reações da fotossintese e faz com que esse íon participe decisivamente no crescimento normal da planta 
.6 .

(LAWTON e COOK, 1954; BLANCHET et alii, 1962; HUMBERT, 1968a; VON UEXUELL, 1968 ).

Além de participar ativamente da fotossíntese, o $\mathrm{K}^{+}$atua diretamente em vários passos metabólicos da sintese de proteína além de ser cofator de aproximadamente 60 enzimas (EVANS e WILDES, 1971 ).

Muitas enzimas, principalmente 1 igadas ao metabolismo de açūcares em cana-de-açūcar requerem $\mathrm{K}^{+}$e outros cätions monovalentes como cofator ( $A L E X A N D E R, 1965 b$ ). Outras envolvidas com as transformações anabólicas e catabólicas de sacarose e hexoses em cana-de-açūcar, como e o caso de invertases, peptase e catalase, parecem necessitar desse íon para suas atividades (HARTT, 1934). Apesar disso, ainda que esteja relacionado com a atividade de tantas enzimas, o potássio ainda constitui um desafio àqueles que desejam elucidar o mecanismo de sua es sencialidade a nível enzimático (MURATA e AKAZAWA, 1968).

Ao contrário dos outros macronutrientes, o potássio não faz parte de nenhum composto orgânico, mas chama atenção, pelo fato de ser o cátion mais abundante no suco celu lar e se encontrar basicamente na forma de sais inorgânicos so 1 úveis, em todos os tecidos de crescimento da planta o que faz supor; ser de grande importância para a divisão celular de tecidos jovens (LAWTON e COOK, 1954). Entretanto, embora já esteja claramente estabelecido que o potássio è essencial para os tecidos em desenvolvimento muitos aspectos bioquímicos do metabolismo celular, ainda não estão completamente elucidados (SCOTT-RUSSEL e CLARKSON, 1971).

ALEXANDER (1965b) cita inūmeros trabalhos rea1izados com cana-de-açūcar em que Hartt correlaciona atividade de enzimas com äreas de formação de açūcar e suprimento de $K^{+}$. 
Baixos níveis de sacarose tem sido encontrados associado com a deficiência de $\mathrm{K}^{+}$em cana(SAMUELS et a $2 i i, 1956$ ). e sendo a sacarose o principal carboidrato armazenado nesta planta, acredita-se que ela seja hidrolisada para produzir açü cares mais simples, como a glucose e a frutose que serão utilizados como fonte de energia e de esqueletos carbônicos durante a germinação e o crescimento (GLASZIOU, 1961).

Um fato interessante que chama a atenção é que o decréscimo de sacarose na parte aērea da cana-de-açü car, muitas vezes independe do suprimento de $K^{+}$, estando re lacionado com a atividade de invertase (GLASZIOU, 1961) e a idade fisiológica da planta (ALEXANDER, 1964).

A cana-de-açūcar, mais do. que a maioria das plantas, parece que tem necessidade de metabolizar glicose durante seus primeiros meses de crescimento e desenvolvimento (ALEXANDER, $1965 \mathrm{a}$ ).

GLASZIOU (1961) observou que a maturação do te cido de armazenamento é sempre acompanhado por um aumento no contefudo de sacarose e uma concomitante diminuição no teor de gliçose e frutose.

A respeito da participação do $\mathrm{K}^{+}$no proces so de fotossintese na cana-de-açūcar, HAEDER e MENंGEL(1974) observaram. que esse íon parece aumentar a taxa de assimilação de $\mathrm{CO}_{2}$ e facilitar a migração de fotossintetados.

HARTT (1969) apresentou provas de que o $\mathrm{K}^{+}$acelera o movimento de fotossintetados da folha de cana-de-açúcar. Posteriormente, HARTT (1970) verificou que o efeito do $\mathrm{K}^{+} \mathrm{so-}^{-}$ bre o processo de translocação, parece estar diretamente rela cionado com o processo de fotofosforilação, pois quando o ní- 
.8.

vel desse íon é alto, ocorre maior estímulo na produção de ATP, que è requerido tanto na translocação de fotossintetados nos tubos condutores, como na acumulação destes, nos tecidos de a mazenamento da cana-de-açūcar, que segundo BIELISKI (1960) se dá contra gradiente de concentração, num processos dependente de energia respiratória.

- MALAVOLTA e CROCOMO (1982) relatam que a participação do $\mathrm{K}^{+}$no processo de fotossíntese, faz com que esse íon atue decisivamente na taxa de crescimento normal das plantas. A cana-de-açúcar, requer para o seu crescimento e metabolismo de grandes quantidades de $\mathrm{K}^{+}$e a exemplo do que ocorre com todas as plantas superiores tem o seu crescimento expresso em termos de elongação,porém, num sentido mais amplo, se inclui o aumento de matéria seca, assim como o aumento de peso e tama nho (DILLEWIJN, 1952 ).

Estudos enzimáticos sobre o processo de acumula ção de açūcares tem mostrado que a sacarose é o principal açūcar que se forma na cana-de-açūcar, conforme demonstram GLASZIOU (1961) e HATCH (1964).

os efeitos benéficos do $\mathrm{K}^{+}$no transporte de fotossintetados em cana-de-açücar são descritos por HARTT (1960) enquanto que o processo de acumulação de açūcares nos tecidos de armazenamento tem sido descritos por GLASZIOU, 1962; HATCH et alii, 1963; HATCH e GLASZIOU, 1963, SACHER et alii,1963 e GLASZIOU e GAYLER (1972), com ênfase na atividade de invertase ácida e invertase neutra, sobre o metabolismo e taxa de crescimento da planta.

Recentemente, estudos sobre o mecanismo de acumulação de sacarose nos tecidos de armazenamento de cana-de-acücar foram realizados dor SAMPIETRO et alii (1980) che- 
garam a importantes conclusões sobre as funções fisiológicas de enzimas invertases. Embora os citados autores não tenham feito referências ao $\mathrm{K}^{+}, \operatorname{HARTT}(1934)$, observou que a ausência desse nutriente afetou tanto a síntese como a translocação não só de açūcares como também de proteínas.

Dados experimentais tem mostrado que o $\mathrm{K}^{+}$é essencial para produzir altos rendimentos em sacarose e a sua omissão resulta em baixas concentrações desse açücar no colmo (SAMUELS e LANDRAU, 1952; HUMBERT, 1963).

Trabalhando com cana-de-açūcar(ALEXANDER, $1973 e$ MADAN et alii, 1980) demonstraram que aḷtos rendimentos de açü car estão relacionados com a presença de invertases nas folhas.

Várias hipóteses têm sido sugeridas, inclusive por aqueles autores, para explicar a divergência desses resultados. Para ALEXANDER (1973), a cana-de-açūcar é considera da, como o ünico sistema "fonte-reservatório" sobre a Terra, uma vez que nenhum outro organismo possui tão perfeita arte de sintètizar, translocar e armazenar açücar em quantidades tão ma ciças.

HARTT et alii (1963) estabeleceram que a sacaro se após sua biossíntese na folha é o principal composto translocade como tal para o colmo. Subsequentemente, (HATCH e GLAS 2IOU, 1963, HAWKER e HATCH, 1964; SACHER et alii, 1963) exp1icam que esse fotossintetado é submetido a uma rápida interconversáo no tecido do colmo antes de ser acumulado e armazenado nos vacüolos.

Para MADAN et alii (1980) parece entretanto plausive 1 , que as invertases presentes na folha, hidrolisem a sacarose em suas hexoses constituintes, as quais subsequentemen te entrarão nas vias metabólicas, daí a concentração 1íquida 
de sacarose que é translocada da fonte para o reservatório ser eventualmente diminuída.

- Muitos estudos têm sido conduzidos para elucidar os mecanismos responsāveis pelas flutuações no conteúdo de açücar, durante o ciclo de desenvolvimento da cultura e, embora um grande nümero de fatores nutricionais e climáticos sejam conhecidos (ALEXANDER, 1964), não se conhecem bem as causas relacionadas com o potássio a nível metabỏlico.

LUGO-LOPEZ e CAPO (1954) enfatizaram os efeitos da temperatura sobre o conteūdo de sacarose. Outros como $S A-$ MUELS et alii, 1952; SAMUELS et alii, 1956; LUGO-LOPEZ, 1954 tem mostrado a importância do solo, dos fertilizantes e variedades. Trabalhando em série, BOWEN (1973; 1975; 1981) mostra os efeitos dos micronutrientes sobre o crescimento e o acümu1o de açúcares nos tecidos de elongação da cana-de-açúcar.

CROCOMO et alii (1981) observaram em cana-de- açücar cultivada em solução nutritiva com diferentes formas nitrogenadas a variação do conteūdo de açücares redutores e sacarose em função de diferentes idades da planta.

OCHOA-ALEJO (1980) cita um grande nümero de trabalhos que dão ênfase a importância do nitrogênio sobre o crescimento e metabolismo e produção da cana. Em trabalho subse quente, OCHOA-ALEJO e CROCOMO (1981) traba1hando com três formas de nitrogênio, demonstraram que tanto o crescimento como o conteüdo de açücares redutores da parte aérea foram maiores nas plantas supridas com nitrato.

Num trabalho parale1o, SILVEIRA e CROCOMO(1981) estudando o efeito do nitrato sobre o metabolismo de cara com seis meses de idade, encontraram baixas concentrações de sacarose e açücares redutores no colmo, enquanto que SILVEIRA(1980) 
utilizando as mesmas condições de cultivo, demonstrou que a existência da relação $\mathrm{K} / \mathrm{N}=0,94\left(2,33 \%\right.$ de $\mathrm{K}^{+}$e $2,41 \%$ de $\mathrm{N}$-total) nas folhas é consi derada ótima para uma concentração máxima de sacarose no colmo.

HUMBERT(1968) trabalhando com seções do colmo maduro de cana-de-açūcar, encontrou uma estreita relação entre o conteūdo de potássio, produção de açūcar, açúcares totais.por centagem de sacarose e pureza do caldo: a medida que o teor de sacarose aumentava a quantidade de açūcares redutores decrescia.

Embora grande parte dos trabalhos encontrados na literatura, que examinam a relação entre o teor de açúcar e a nutrição das plantas, tratem mais da influência do potássio ou das interações nitrogênio/potássio, é sabido que em termos de nutrição e adubação de cana-de-açūcar,o potássio,supera em quan tidade, o nitrogênio, uma vez que esta cultura requer quantidades de potássio,muito mais do que o nitrogênio e qualquer outro ma cronutriente (VON UEXUELL, 1968 e MALAVOLTA, 1982). Entretanto apesar de existir um certo paralelismo entre potássio e teor de açucares bem poucos são os trabalhos que interrelacionam potássio com produção de açúcares e atividade de enzimas invertases.

De acordo com ALEXANDER(1965a) de todos os fato res que afetam o conteūdo de sacarose e açūcares redutores em cana-de-açúcar, a invertase,é sem dúvida alguma, a principal res ponsável e talvez baseada nisso,HARTT(1934) tenha fornecido evidências indiretas de que a sacarose pudesse ser sintetizada na folha por uma invertase e que o potassio fosse provavelmente ur: ativador específico desta enzima em cana-de-açūcar. Entretanto,estudos enzimáticos feitos por GOODWIN e MERCER(1972), mostram que em cana-de-açúcar a sacarose não é sintetizada pe1 a invertase mas por uma reação envolvendo a sacarose-fosfato-sintetase e uma fosfatase, ambas presentes nas folhas, mais especificamente nos cloroplastos, conforme DAVIES(1974). 
2.2. Consequéncias do suprimento inadequado de $K^{+}$no metabo lismo da planta

Segundo EVANS e SORGER (1966), uma das formas de se conhecer a função metabólica de um elemento vem a ser através do éstudo das consequências de sua deficiência. Esse tipo de investigação as vezes revela dados suficientes, capazes de sugerir os bloqueios metabólicos ou os 1ocais específicos onde ta 1 elemento atua.

0 efeito da deficiência de potássio na trans1ocação dos açúcares das folhas para outros órgãos é clássico da 1iteratura; plantas deficientes translocam menos que as bem supridas do elemento (MALAVOLTA, 1980).

Em cana-de-açūcar, HARTT (1934) mostrou que a deficiência de $\mathrm{K}^{+}$podia interferir não somente com a trans1ocação mas também com a tranśformação tanto anabólica de hexoses e sacarose. Esse estudo parece ter sido o ponto de partida, para uma série de trabalhos visando compreender o significado do K no metabolismo da planta a nível enzinático

Nos resultados de ALEXANDER (1964) vê-se que o suprimento inadequado de potássio a 1 ém de reduzir os teores de sacarose no colmo da cana-de-açücar, fez cair também o teor de amido; observou-se ainda nesse ensaio, um maior teor de açücares e de $\mathrm{N}-\alpha \mathrm{NH}_{2}$ solüve1; resultados semelhantes foram obtidos por HARTT (1934) e HUMBERT (1963).

Enquanto que os mais baixos teores de sacarose no colmo da cana-de-açücar deficiénte em k, pode ser devido a menor produção pela fotossíntese e diminuicão no transporte da folha para'aquele órgão (HUMBERT, 1963); o acúmulo de açücares redutores é frequentemente atribuído à atividade inadequada de certas enzimas da g1icólise e que requerem potássio como cofa tor (ALEXANDER, 1964). 
Apesar das evidências desses resultados, HARTT

(1934) mostrou que outras enzimas da cana-de-açúcar tais como a invertase e a amilase tiveram suas atividades afetadas pela deficiência de potássio,embora pouca atenção tenha sido dada para essas gi icosidases.

SHEA et alii (1967) afirmaram que as plantas se diferenciam quanto a utilização de potássio. As plantas de ca na-de-açúcar embora eficientes na utilização desse nutriente, podem não apresentar quando deficientes, uniformidade nos padrões dos desarranjos metabólicos. Esses, podem variar quanto a espécie, o estádio de desenvolvimento da planta e a ação de fatores externos (HATCH, 1964 e EPSTEIN, 1972).

HARTT (1969) mostrou que até mesmo uma ligeira deficiência de $\mathrm{K}^{+}$em cana-de-açúcar, diminuỉa a translocação de assimilados antes mesmo de causar um decréscimo na velocidade de fotossintese. Essa diminuição na translocação dos assimila dos da fotossintese levou a autora a concluir que a deficiência do $\mathrm{K}^{+}$interfere diretamente sobre o desenvolvimento dos sin tomas visuais, velocidade de crescimento, teor de umidade, a f xação de $\mathrm{CO}_{2}$ ou conversão de intermediários a produtos. De qual quer modo a interferência direta da deficiência de $\mathrm{K}^{+}$com a fo tossintese se torna provável devido relações do elemento com o c1oroplastos (EPSTEIN, 1972).

ALEXANDER (1964) por sua vez observou que as aplicações de potássio à solução nutritiva, aumentaram o conteūdo uruto de clorofila nas folhas e a percentagem de sacarose no caldo. Por outro lado, o suprimento inadequado desse nutriente reduziu consideravelmente o teor de clorofila e a taxa de fotossintese. HARTT e BURR (1967) também encontraram corre lações positivas entre a baixa taxa fotossintética e baixos teores de $K$ nas folhas de cana-de-açúcar. 
HARTT (1970) e ALEXANDER (1973) mostraram que não só a fotossintese mas também o transporte de carboidratos são influenciados pela falta de $K^{+}$na cana-de-açúcar. Pressupõem os autores que, em tal condição, a sacarose que é o prin cipal fotossintetado de reserva da planta, tenha sua biossínte se e translocação inibidas, por alterações das enzimas envolvi das, principalmente sacarose-sintetase e sacarose-fosfato-sintetase das quais o $k$ é ativador.

Quanto ao processo de respiração em cana-de-açu car, DILLEWINJ (1952) relata que ocorre geralmente em colmo de plantas jovens diminuindo gradualmente com o crescimento do in ternódio, o que sugere que os tecidos jovens podem conter uma mais a 1 ta concentração de $\mathrm{CO}_{2}$, do que os tecidos mais velhos. 0 inverso poderá ser verdadeiro para a concentração de oxigênio.

Em folhas de cana-de-açúcar deficiente em $\mathrm{K}^{+} \mathrm{a}$ taxa de respiração, aumentou ao mesmo tempo que diminuiu a trans locação de assimilados sendo os dois processos afetados antes que a taxa de fotossintese começasse a diminuir (HARTT, 1969 e OZBüm et alii, 1965).

Quanto a utilização do $\mathrm{K}^{+}$pelas plantas com particular referência às interrelações entre metabolismo de carboidratos e proteínas, HARTT (1934) citando vários autores relata que o acúmulo de carboidratos em plantas deficientes em $\mathrm{K}^{+}$ é causado principalmente por uma desorganização na sintese de proteinas.

HARTT (1934) demonstrou que as plantas de ca na-se-açūcar deficientes em $K$ apresentaram distürbios na sinte 
se e translocaçăo de proteínas e açücares; necrose no floema; acúmulo de Fe nos nos; forte atividade de amilase e fraca atividade de invertase que foi mais afetada no colmo que na folha.

Muitos outros autores, que tem estudado os efei tos do potássio sobre o metabolismo de plantas de cana-de-açū car, cultivadas, em solução nutritiva, mostram as consequências da deficiência desse íon. Paralelamente, tentam correlacionar os distūrbios metabōlicos resultantes à atividade inade quada de muitas enzimas envolvidas no metabolismo de açúcares e que necessitam do $\mathrm{K}^{+}$como cofator.

Dentre todos os resultados, os que se apresen tam mais estreitamente relacionados com a deficiência de $\mathrm{K}^{+}$em plantas joven's de cana-de-açūcar são: a) acúumulo de açūcares redutores e redução de sacaroṣe nas folhas, atribuído principalmente a mesma atividade de fosfohexoisomerase e fosfofrutoquinase apesar da atividade de invertase ter se apresentado re duzida (ALEXANDER, 1964); acūmulo de sacarose e diminuição na atividade de algumas enzimas principalmente $\beta$-amilase (ALEXAN$D E R$, 1973) e c) diminuição de sacarose e açücares redutores tan to nas folhas como no colmo ocasionada por alteraçoes metabó1icas ao nível enzimático (SILVEIRA, 1980).

A discordância dos resultados é explicada pela diferença de comportamento de uma mesma enzima quando se trabalha com diferentes variedades conforme observaram ALEXANDER (1965a; 1967) e MADAN et alii (1980).

HARTT (1934) cita inūmeros autores que mencionam a presença de enzimas tais como diastase, peptase, ereptase, catalase, oxidase, peroxidase, maltase e amilase que tem sido encontradas em tecidos de cana-de-açūcar mas que tem sido insuficientemente estudadas.

Nason (1962) e White (1966), citados por EVANS 
e SORGER (1966), relatan que a deficiência de $\mathrm{K}^{+}$afeta o conteúdo de proteínas nos tecidos e a atividade de diastase e invertase.

ORLANDO FILHO (1982) citando Alvarez e Haunk relata que em plantas com deficiência de $\mathrm{k}^{+}$, ocorreu um aumento na atividade hidrolitica de invertase, elevando desse modo, a quantidade de açūcares redutores na cana-de-açūcar.

Inūmeras investigações bioquímicas indicam que o metabolismo dos compostos nitrogenados é grandemente afe tado pela deficiência de $\mathrm{K}^{+}$. Sob tal condição as plantas apresentam um acúmulo de aminoácidos, amidas e outros compostos nitrogenados bem como redução nos teores de proteína (EVANS e SORGER, 1966).

0 acúmulo de $\mathrm{N}-a \mathrm{NH}_{2}$ solūvel em plantas deficien tes em potássio tem sido objeto de algumas controvérsias. Enquanto que alguns pesquisadores apontam como causa principal uma diminuição na sintese de proteínas (LAWTON e COOK, 1954 ; KOCH e MENGEL, 1972) provas apresentadas por HSIAO et alii(1970) não aprovam éssa hipötese. Esses autores verificaram que nas plantas deficientes, a concentração de proteína até aumentou e somente ocorreu acúmulo de $\mathrm{N}-a \mathrm{NH}_{2}$ (= aminoācidos 1 ivres) em ca sos de extrema deficiência.

Existem värios trabalhos relatando que em condi ções de severa deficiência de $\mathrm{K}^{+}$as plantas acumulam aminas tó xicas,principalmente putrescina (RICHARD e COLEMAN, 1952 ; SMITH e SINCLAIR, 1967; CROCONO e BASSO, 1974; BASSO, $1974 e$ 2AGO, 1978) que ocorre principalmente nas regiões lesadas com clorose e necrose (MALAVOLTA, 1980) das folhas mais velhas (MEN- 
GEL e KIRBY, 1978 ).

Outra característica da deficiência de $\mathrm{K}^{+}$em cana-de-açūcar è a ocorrência de altos teores de cālcio,magnēsio, fósforo e ferro (HARTT, 1934) e mais, N-total, silício e enxofre (DILLEWIJN, 1952). De acordo com este ültimo autor, o aumento do conteúdo de Fe, acumulado nos nós do colmo, pode estimular o desenvolvimento do sistema radicular das plantas deficientes, enquanto que o a umento do $N$ como consequência da deficiência de $\mathrm{K}^{+}$, vai afetar a sintese de proteínas, possive 1 mente por morte dos tecidos condutores.

Quanto aos aspectos morfológicos, a deficiência de potässio em plantas de cana-de-açúcar se revela de modo bastante caracteristico: o crescimento da planta è diminuído, os colmos são finos com os internōdios curtos. As folhas mais velhas perdem aos poucos a cor verde, apresentando manchas amareladas que depois ficam pardas e mortas com maior concentração nas pontas e margens. Na superfície supe rior da nervura principal, aparecem manchas avermelhadas de coloração mais escura na base das folhas, que são mais estreitas do que as plantas normais (DILLEWIJN, 1952; HUMBERT, 2963); HAAG, 1965; VON UEXUELL, 1968; SILVEIRA, 1980 e MALAVOLTA,1982).

2.3. Função das invertases no metabolismo de açücares em cana-de-açūcar

A invertase ( $\beta-D-f r u t o f u r a n o s i d e$ frutohidrolase, EC, 3.2.1.26) catalisa a formação de glicose e frutose a partir da sacarose $(\alpha-D-g 1$ icopiranosil $[\alpha-1-2]-\beta-D-f r u t o f u r o n o-$ se) conforme mostram KOSHLAND e STEIN(1954) e ALEXANDER(1965a) pela reação: 
.18.

$$
\left.\begin{array}{rl}
\text { Sacarose }+\mathrm{H}_{2} \mathrm{O} & =\text { Glucose }+ \text { Frutose } \\
\Delta \mathrm{G}^{\prime} & =-6.600 \text { cal/mole } \\
\mathrm{K} & =6,95 \times 10^{4}
\end{array}\right\} \mathrm{PH} 7,0
$$

0 equilíbrio desta reação é muito mais a favor dos produtos de hidrólise e todas as tentativas para tornar a reação reversível tem sido mal sucedida, o que mostra que a sa carose não é sintetizada em tecidos de plantas pela reversão da reação catalizada pela invertase (GOODWIN e MERCER, 1972), o que vai de encontro com a afirmativa de HARTT (1934) que apresentou evidências de que a sacarose é sintetizada pela invertase nas folhas de cana-de-açücar.

De acordo com WARD (1953) e ALEXANDER (1965a) vạ rios substratos além da sacarose podem ser hidrolizados tais como rafinose, gentianose, estaquiose e hesperonal. A hidro1 ise da sacarose segundo estes autores, tem sido frequentemente chamada de inversão, uma vez que é acompanhada por uma mudança de valores positivos (dextro) para negativos (levo) na mistura equimolar de glucose e frutose que pode ser acompanhada por polarimetria. Dessa mudança na rotação ótica surgiu o nome invertase, embora muitos pesquisadores ainda prefiram denominä-1a de "Sucrase" e "Sacarase" ou nomes mais específicos como $\alpha$-glicosidase e $\beta$-frutosidase.

A invertase é membro de um grupo de enzimas hidroliticas denominadas glicosidases encontradas em cana-de- açūcar como é o caso das trealases e B-amilases (ALEXANDER, 1965a; GLASZIOU e GAYLER, 1972; PRADO et alii, 1978; SAMPIERRO et alii, 1980 e ETCHEBERRIGARAY et alii, 1981).

ALEXANDER (1969) em estudos comparativos entre a 'invertase de levedura e a invertase de cana-de-açūcar, obse vou que a invertase de levedura possuia somente atividade B-fru tosidase enquanto que a invertase dos tecidos jovens da cana era um complexo formado de tres carboidrases: B-frutosidase, 


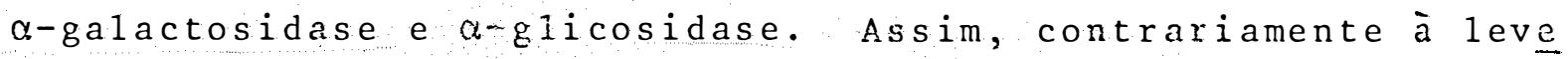
dura que é uma forma de vida primitiva, uma planta superior tal como a cana-de-açúcar, requer para as transformações fisio lógicas e bioquímicas de carboidratos, um complexo enzimático de maior grau de versatilidade (ALEXANDER, 1969). Esses fatos estão de acordo com WARD (1953), o qual através de esiudos chegou a conclusão de que a invertase de levedura parece ter atividade de uma enzima simples, ao contrário da atividade de invertase de cana-de-açúcar que parece ser constituída de diferentes tipos de enzimas, organizadas em um complexo multienzimático, diferenciadas pelas suas propriedades cinéticas (SHANON, 1968) e localização celular (PRADO et alii, 1978).

ALEXANDER (1965a) sugeriu que tentro do grupo "invertase ācida" existem pelo menos duas' enzimas e que as $\alpha$-glicosi dases podem servir como constituintes para o mecanismo de degradação dos polissacarídeos em cana-de-açúcar.

QUIROGA et alii (1977) demonstraram que as invertases do colmo de cana-de-açūcar estão acompanhadas de outras glicosidases tais como $\alpha$ e $\beta$-galactosidase.

No esquema da Figura 1, ALEXANDER (1965a! mostra as glicosidases encontradas normalmente em plantas jovens de cana-de-açúcar.

GAYLER e GLASZIOU (1972) encontraram em cana-de-açūcar três formas de invertase, tendo diferentes valores de pH ót mo $(3,8 ; 5,5$ e 7,1). Suas localizações na célula e funções fí siológicas foram por eles examinadas durante o crescimento e a maturação do colmo. No desenvolvimento do internódio, onde existem dois estägios distintos de desenvolvimento celular, eles encontraram diferentes sistemas de invertases: o invertase $\vec{a}-$ ácida soíúvel ( $\mathrm{pH} 5,0-5,5)$ apareceu em grandes quantidades tan to no espaço externo como no parênquima de armazenamento duran 
.20 .

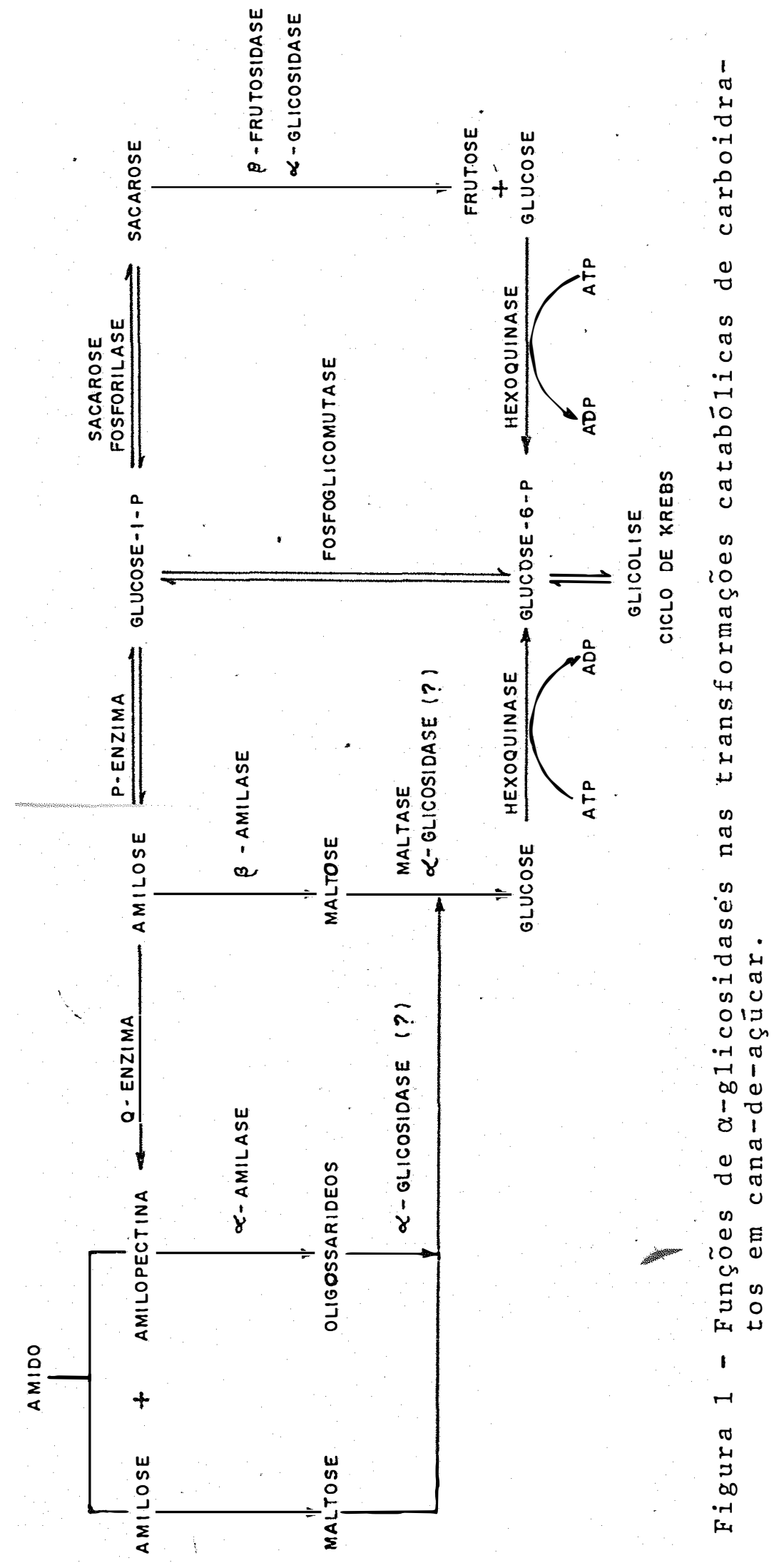


te todo o processo de divisão e diferenciação celular, desapa recendo gradualmente quando o internódio parou de crescer. As cêlulas maduras continham uma invertase ácida insolúvel ligada à parede celular $(\mathrm{pH} 3,8)$ e uma invertase neutra $(\mathrm{pH} 7,0-7,1)$ que aumentou durante a maturação. HATCH e GLASZIOU (1963); SIJACK (1965); HAWKER e HATCH (1965); GLASZIOU e GAYLER(1972) e ALEXANDER (1973) encontraram esses mesmos resultados.

As invertases encontradas em cana-de-açūcar são consideradas enzimas oligoméricas (ALEXANDER, 1967 e MARETZKI e ALEXANDER, 1.967) que exigem $\mathrm{Mn}^{2+}$ como cofator conforme demonstraram ALEXANDER (1965a) e QUIROGA et alii (1977).

HARTT (1934) apresentou evidências de que o $\mathrm{K}^{+}$ é um ativador específico dé invertase em cana-de-açücar, mostrando que a interrelação potássio/enzima pode ser: 1) direta, atravēs da inclusão do $\mathrm{K}^{+}$ṇa composição química da enzima ou atravēs do seu efeito como ativador; 2) indireta, regulando a concentração de íon hidrogênio, ou o sistema tampão e, 3) anta gônica, contrabalançando os efeitos dos fatores inibitórios. Apesar disso, a literatura sobre o efeito do $\mathrm{K}^{+}$como ativador de invertase em cana-de-açūcar é escassa embora recentemente, MATSÜSHITA e URITANI (1974) tenham sugerido que o $\mathrm{Na}^{+} \mathrm{e} \mathrm{K}^{+} \mathrm{s}$ ão ativadores de invertases em batata doce.

HATCH et alii, 1963 ; HAWKER e HATCH, 1965; GLAS ZIOU e GAYLER, 1972; SAMPIETRO et ali $i, 1980$ em muitos de seus trabalhos tem mostrado que as invertases presentes em cana-de- açūcar estão divididas em dois grupos de enzimas: um grupo consiste de invertases da parede celular e o outro de enzimas intracelulares tendo ambos os grupos diferentes funções fisiolögicas. As invertases da parede celular estão envolvidas com o mecanismo de translocação de sacarose do apoplasto para o simplasto de cana-de-açúcar, enquanto que as enzimas intracelu lares estão provavelmente envolvidas com a mobilização da saca 
rose no vacuolo, ou seja, estão ligadas ao metabolismo celular. SAMPIETRO et alii,(1980) e VATTUONE et alii, (1981).

Em tecidos imaturos e adultos da baínha de fo1has de cana-de-açúcar, VATTUONE et alii (1981), também encontraram um complexo de três diferentes invertases firmemente 1 i gadas à parede celular que diferem em $\mathrm{K}_{\mathrm{m}}$, $\mathrm{pH}$ ótimo e resposta a inibidores. Este complexo de invertases dos tecidos imaturos difere de uma única enzima alcalina ou neutra que aparece nos caules maduros.

Conforme GAYLER e GLASZIOU (1972) uma das mais importantes funções da invertase àcida é suprir a célula de glucose e frutose que pode aumentar em hexoses e não em sacaro se, 'como observaram em internódios imaturos de cana-de-açūcar, enquanto que a invertase neutra que parece fazer parte do sistema que controla o fluxo de açucares em tecidos maduros.

\section{ALEXANDER e SAMUELS (1968) e ALEXANDER (1973) tem} subsequentemente relatado que as invertases não estão presentes em folha de cana, enquanto que PRADO et alii (1979) e SAMPIETRO et alii (1980) encontraram essas enzimas na baínha da folha. Esses dados estão de comum acordo com HATCH et ali (1963) que isolaram uma invertase ácida na folha e na baínha de piantas jovens de cana. A invertase ácida de tecidos jo vens armazenadores mostraram uma notável variação sazonal de atividade: o período de maior atividade correspondeu ao perío do de maior crescimento.

Segundo ALEXANDER (1973) a baínha foliar 巨o ör gão ideal para se estudar a atividade de invertase por ser o suporte dos örgãos condutores, servindo como uma ponte de 1 igação entre o local de síntese ( 1 imbo foliar) e o de armazenamen to (colmo). E através da baínha que a sacarose passa para o parênquima de armazenamento do caule. 
Para GAYLER e GLASZIOU (1972) a invertase àcida solúvel é secretada na região meristemática durante a fase de formação das células, predeterminando nestas, a disponibili dade de carboidratos que serão utilizados durante a fase de crescimento. Nesta fase nenhuma enzima mais è secretada e aquelas existentes são inativadas lentamente à medida que o te cido se torna adulto.

A esse respeito SAMPIETRO et alii (1980) observaram que em cana-de-açúcar altas concentrações de sacarose podem suprimir parcial ou totalmente a função reguladora da invertase ácida que passa a ser exercidá pela invertase neu tra indicando a maturidade do tecido para acumular sacaro se.

Em relação ao potássio poucos autores além de HARTT (1934) e ALEXANDER (1964) tem observado os seus efeitos sobre a atividade de invertase embora esta enzima e a sintetase de sacarose desempenhem funções importantes e que, juntas respondem principalmente pelo metabolismo bioquímico de síntese e armazenamento de sacarose em cana-de-açūcar.

os autores mostram uma correlação existente en tre o padrão enzimático do colmo em crescimento e a deficiência de potássio, sendo de grande importância o estudo da evolução enzimática do colmo utilizando-se diferentes níveis de potásio. A existência de uma correlação positiva en tre a quantidade de potássio fornecido e o teor de açūcar armazenado também foi apresentada: a concentração de açúcar no colmo dependeu do grau de deficiência de $\mathrm{K}^{+}$. Na deficiência branda, as plantas parcialmente destituidas de $\mathrm{K}^{+}$continham mais açucares redutores e menos sacarose do que as plantas nor mais; na deficiência severa, as plantas totalmente privadas de $\mathrm{K}^{+}$o teor de açúcares redutores foi tão baixo quanto o de sacarose. 
GAYLER e GLASZIOU, 1972, citando Hatche Glasziou, 1964 relatam que todo carboidrato proveniente da folha está na forma de sacarose. Esta não pode penetrar na membrana celular sem a prévia hidrólise por uma invertase (HAWKER e HATCH, 1965; SACHER et alii, 1963 e BOWEN, 1972). Devido a isto ficou evidenciado a função fisiológica de invertases não so mente na utilização de sacarose mas também nos processos de ar mazenamento de açücar (PRADO et alii, 1978).

Estudos sobre o movimento de açūcar nas célu1 as do parenquima celular indicaram que a invertase ácida solú vel está localizada em dois compartimentos celulares - no espa ço externo e no compartimento armazenador no qual pode estar incluído o vacuolo (SACHER et alii, 1963). E desde que a inversão da sacarose parece constituir um pre-requisito para a sua entrada no metabolismo, considera-se que no espaço externo a enzima regula o movimento da sacarose no tecido, enquanto no espaço interno do tecido armazenador, ocorre a inversão da sacarose mediada pela enzima que é inativada durante os estágios de maturação (GLASZIOU, 1962). Segundo este autor, o mecanis mo pelo qual a sacarose é invertida em tecidos armazenadores de cana-de-açúcar tem sido estudado por muitos autores e todos os resultados mostram que uma enzima do tipo invertase é a responsável pela inversão.

SACHER et alii (1963) demonstxaram Aque a sdcaro se é invextida na passagem do espaço externo pera o interior do compartimento armazenador onde reaparece como sacarose. provävel que a sacarose seja ressintetizada no compartimentome tabólico da célula e armazenada no compartiment armazenador.

Estudos relacionados com o mecanismo de acumula ção de sacarose nos tecidos de armazenamento de cana-de-açücar tem mostrado importantes conclusões sobre a função fisiológica das enzimas invertases (SAMPIETRO et ali $i$, 1980). Essas en- 
zimas juntamente com a sacarose sintetase (E.C.2.4.1.13) desem penham funções específicas, como sejam, a hidrólise, a síntese e armazenamento de sacarose (ALEXANDER, 1973). De acordo com este ültimo autor, a sacarose é rapidamente hidrolisada pela atividade de uma invertase ácida vacuolar e, no citoplasma, as hexoses resultantes são utilizadas durante o metabolismo de crescimento celular.

O ciclo de acumulação de açúcares em tecidos de armazenamento de colmo de cana-de-açúcar tem sido sugerido por vārios autores entre eles GLASZIOU (1961), SACHER et alii(1963), HATCH e GLASZIOU (1963) e HATCH (1964) tentando explicar o mecanismo de acúmulo de açúcares a nível celular. Segundo o es quema proposto por HATCH (1964) a hidrólise da sacarose pela invertase foi o primeiro passo para a acumulação de açúcares, enquanto que o composto que se move através da membrana è a sacarose-fosfato (SACHER et alii, 1963). Os passos que levam a formação de UDP-glucose e hexoses-fosfatos tem sido relatados por HATCH et alii (1963) e SACHER et ali i (1963).

HATCH (1964) relata que a sintese e subsequente hidrōlise da sacarose poderia prover um gasto de energia necessária para as condições termodinâmicas do processo. Embora a 1itera tura sobre os efeitos do $\mathrm{K}^{+}$sobre de invertase seja escassa, $A L E-$ XANDER (1965a) cita inúmeros trabalhos em que HARTT correlaciona ati- . vidade da enzima com āreas de formação de açūcares e suprimento de. potássio, em cana-de-açūcar.

Os efeitos benéficos de $\mathrm{K}^{+}$no transporte de fotosisintetados à longa distância,foram descritos por HARTT (1969) para a cana-de-açúcar enquanto que HATCH et alii(1963) enfatiza a participação da enzima invertase na translocação de sacarose para o colmo. De acordo com BERINGER (1982) nos processos que levam a produção, à 1 uz das relações fonte-reservatōrio, o $\mathrm{K}^{+}$parece agir como umestimulador da fonte, isto é, do suprimento de fotosintetados para os órgãos de armazenamento. 
Embora nos diferentes trabalhos que tratam das funções do potássio como ativador enzimático, não se encontre dados concretos de que ele seja ativador específico de inverta se em cana-de-açúcar, vários autores tem investigado em outras plantas, as relações entre atividade de invertase e estágios de desenvolvimento (ROBINSON e BROWN, 1952; WARD,1953; SEITZ e LANG, 1968; HELLEBUST e FORWARD, 1962; MACHACHLAN et ali $i$, 1970; JONES e KAUFMAN, 1975; SUM et ali $i, 1980$ e HUMPHREIS e ECHEVERRIA， 1980).

$$
\text { Outros autores como JONES (1966), RICARDO e }
$$

SOVIA (1974) estudaram os efeitos da deficiência de nutrientes minerais sobre a atividade de invertases em sucess vos estádios de desenvolvimento das plantas.

\section{Num trabalho realizado por ROBINSON e BROWN} (1952) eles sugerem que dois diferentes sistemas de invertases e que hidrolizam a sacarose podem estar presentes em diferentes segmentos da räiz de feijão em desenvolvimento. Esses auto res postularam que o crescimento da célula depende das mudanças relativas do desenvolvimento, envolvendo uma sucessão de estádio metabólico o que foi observado em cada segmento da raiz.

HELLEBUST e FORWARD (1962) trabalhando com segmentos de raízes de milho e RICARDO e SOVIA (1974) com raízes tuberosas, estudaram a distribuição da atividade de in vertase em regiões de crescimento nos sucessivos estádios de desenvolvimento, incluindo ainda o estudo da distribuição do teor de sacarose e açúcares livres,principalmente glucose e frutose sendo que os últimos autores, ainda relacionaram ativi dade de invertase com acumulação de açúcares e nutrição mineral.

Enquanto que MACLACHLAM et alii (1970) observa ram em seções de epicotilo de ervilhas em sucessivos estádios 
de desenvolvimento, notáveis diferenças entre os níveis de glu cose e frutose que foram devidas a mudanças na velocidade de transporte, utilização ou formação de uma ou de outra hexose.

$$
\text { Assim, elevadas atividades de, invertase ácida }
$$

que são característicos das células vegetais em desenvolvimento poderia ser um pré-requisito para prencher a grande demanda de hexoses requeridas para um räpido desenvolvimento. Värios estudos tem de fato sugerido uma estreita relação entre os te'cidos de crescimento e a atividade de uma invertase àcida ( $R O-$ BINSON e BROWN, 1952; HELLEBUST e FORWARD, 1962; HATCH e GLAS2IOU, 1963; MACLACHLAN et alii, 1970). 
3. MATERIAL E METODOS

\subsection{Cultivo das plantas e preparo do material}

0 ensaio foi conduzido em casa de vegetação,com solução nutritiva, utilizando plantas jovens de cana-de-açúcar (Saccharum spp. var. NA5.9-76). obtidas de calos pelo método de CROCOMO et alii (1979) e cedidas pelo laboratório de Cultura de Tecidos da Seção de Bioquímica de Plantas do Centro de Ener gia Nuclear na Agricultura (CENA), em Piracicaba, São Paulo.

As plantinhas que há 3 semanas cresciam em co. pos plásticos com vermiculita sob condições controladas de uma câmara de crescimento, foram transferidas para bandejas com ca pacidade para 40 litros contendo 30 litros da solução nutritiva completa de HOAGLAND e ARNON (1950) diluída na proporção de $1: 10$ e que serviu como suporte inicial para o crescimento, a $\vec{i}$ permanecendo por 30 dias.

Após esse período, as plantas distribuídas ao acaso foram transplantadas para outras bandejas contendo 301 i tros das soluções nutritivas definitivas, preparadas conforme SARRUGE (1975) e cujas composições são apresentadas na Tabe 1a 1. Cada solução correspondeu a um tratamento que consis tiu na presença de todos os nutrientes e na omissão de $K^{+}$que foi adicionado separadamente nas concentrações de 0,1, 6,0 e 
Tabela 1 - Composição das soluções nutritivas utilizadas.

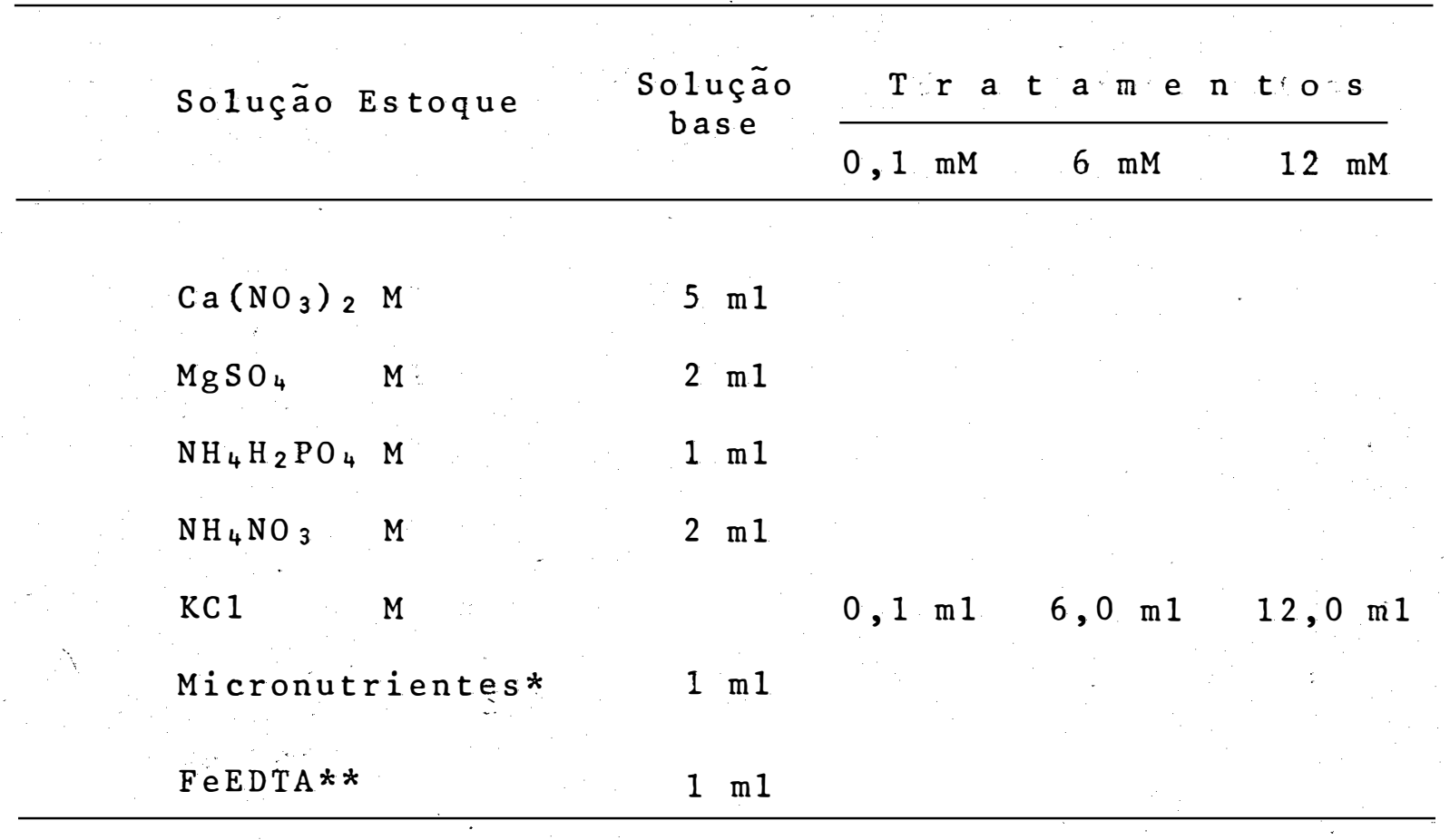

As concentrações de KCl são $0,1 \mathrm{mM}, 6 \mathrm{mM}$ e $12 \mathrm{mM}$.

*A solução de micronutrientes contém $2,86 \mathrm{~g}$ de $\mathrm{H}_{3} \mathrm{BO}_{3}$; $1,81 \mathrm{~g}$ de $\mathrm{MnCl}_{2} \cdot{ }_{4} \mathrm{H}_{2} \mathrm{O} ; 0,21 \mathrm{~g} \mathrm{ZnCl} ; 0,04 \mathrm{~g}$ de $\mathrm{CuCl}_{2} \mathrm{e}$ $0,02 \mathrm{~g}$ de $\mathrm{H} \mathrm{MOO}_{4} \cdot \mathrm{H}_{2} \mathrm{O}$ em um 1 itro.

**A solução de Fe-EDTA contém 26,1 g de EDTA dissódico (ácido) em $286 \mathrm{ml}$ de $\mathrm{NaOH} 1 \mathrm{M}$ e 24,9 de $\mathrm{FeSO}_{4}{ }_{7} \mathrm{H}_{2} \mathrm{O}$ por 1 itro. 
12,0 mM. Utilizou-se como fonte de potássio o KC1, correspondendo cada concentração respectivamente aos tratamentos, $K_{1}$, $\mathrm{K}_{2} \cdot \mathrm{e} \mathrm{K}_{3}$.

Durante o experimento (60 dias) as plantas foram mantidas nessas soluções cujo pH variou de 5,5 a 6,0 .

De 10 em 10 dias procedeu-se a substituição das soluções nutritivas e os volumes iniciais foram completados sempre que necessário. $\Lambda$ cada 20 dias, plantas de cada tratamento foram colhidas e separadas em parte aérea e raiz que foi desprezada.

A parte aérea destinada às determinações, foi dị vidida en três segmentos (Figura 2) que variaram de $10 \mathrm{~cm}$ (aos 20 dias) até $50 \mathrm{~cm}$ (no final do experimento). Cada segmento foi cortado em pedacinhos, acondicionado em sacos de papei de aluminio devidamente etiquetados e levado para liofilizar até peso constante.

Após a liofilízação, todo esse material foi pesado obtendo-se os dados de natéria seca, depois moído, coloca do em frascos de vidros e guardado em dessecadores na câmara fria, para anälises posteriores.

Dados de crescimento, atividade de invertase ácida e invertase neutra, teor de $\mathrm{K}^{+}$, conteúdo de carboidratos como sacarose, ậucares redutores, açúcares redutores totais e de compostos nitrogenados como proteinas, $\mathrm{N}$-total e $\mathrm{N}-\alpha-\mathrm{NH}_{2}$ so lüvel foram obtidos dos diferentes segmentos.

Conforme a Figura 2, cada segmento da parte a ê rea da planta,correspondeu respectivamente aos tecidos: (a) da bainha/colmo (segmento inferior), (b) do colmo/folha (segmento médio e (c) somente das folhas (segmento superior). 
.31 .

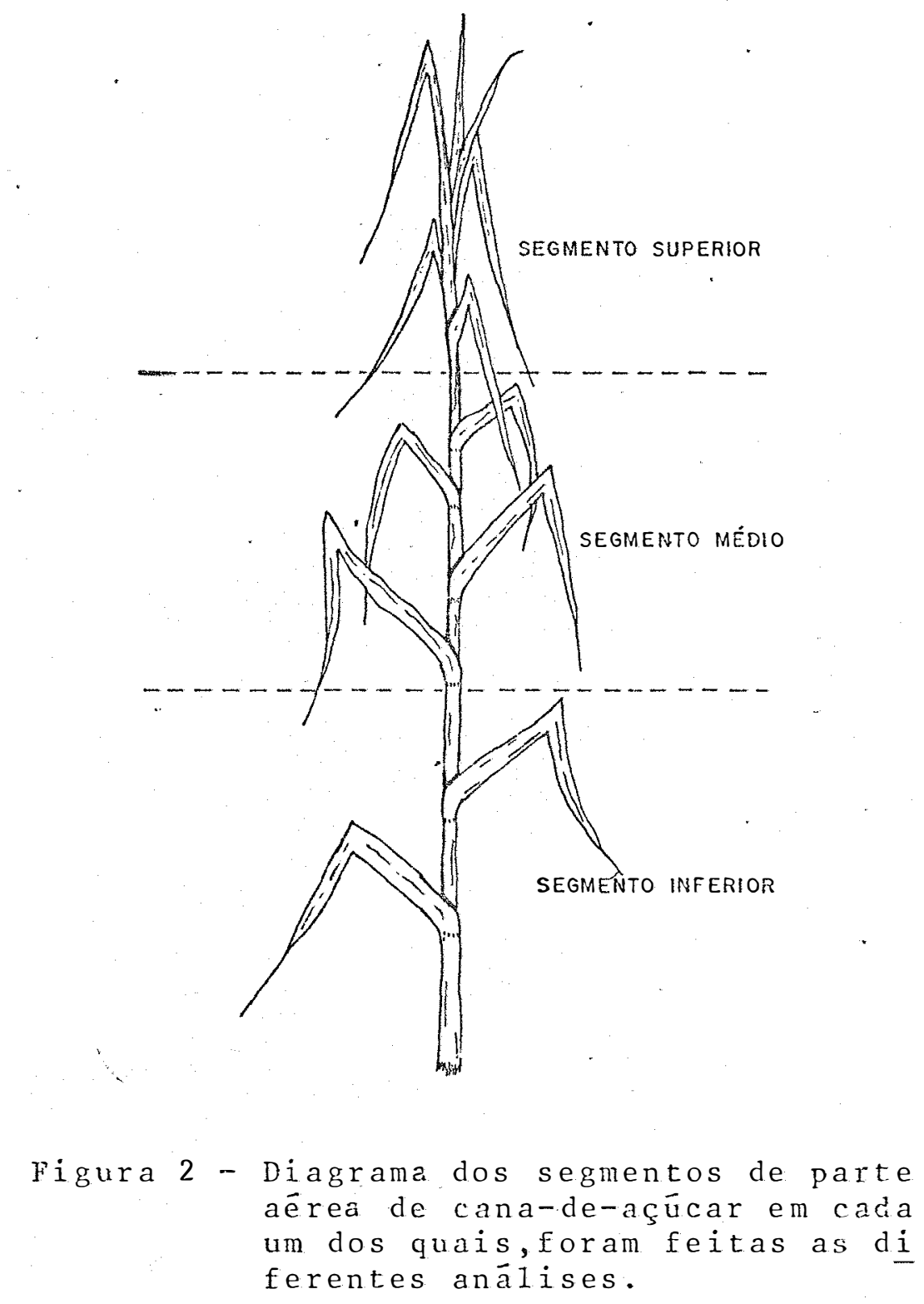




\title{
3.2. Anālises quĩmicas
}

\subsubsection{Determinàção de carboidratos}

\author{
3.2.1.1. Açūcares redutores $(A R)$, açūcares redü \\ tores totais (ART) e sacarose \\ 3.2.1.1.a) Extração
}

Os açücares redutores foram extraỉdos pelo méto do descrito por OCHOA-ALEJO (198). Amostras de $100 \mathrm{mg}$ de material liofilizado e pulverizado, aquecido em banho-maria a $85^{\circ} \mathrm{C}$ por 15 minutos com $4 \mathrm{~m} 1$ de etanol a $80 \%$ e 1 logo após o resfriamento, centrifugado a $6.000 \mathrm{rpm}$ durante $10 \mathrm{minutos}$. 0 sobrena dante foi coletado e reextraído por mais duas vezes com $3 \mathrm{ml}$ de etanol, juntando-se no final, os 3 extratos e completando ao volume de $10 \mathrm{~m} 1$ com etano1 a $80 \%$. O sedimento foi reservado pa ra posterior extração de proteína.

os açúcares redutores totais (ART) foram extrai dos submetendo-se o extrato alcó́lico ( $2 \mathrm{ml})$ à ação de $4 \mathrm{~m} 1$ de HCl $0,75 \mathrm{~N}$ que hidrolizou os oligossacarídeos nele contidos à temperatura de $65^{\circ} \mathrm{C}$, durante 30 minutos. A seguir, esse hidro lizado foi neutralizado com $4 \mathrm{ml}$ de $\mathrm{NaOH} 0,75 \mathrm{~N}$ e levado ao vo 1 ume de $10 \mathrm{~m} 1$ com água destilada conforme modificações ao méto do de AMORIN e Z.AGO (1978).

\subsubsection{1.b) Quantificação}

o conteūido de açūcares redutores (AR) e Açūcares Redutores Totais (ART) foi determinado pejo método de NELSON (1944). Aliquotas de respectivamente 0,1 e $0,2 \mathrm{~m} 1$ foram co 
locadas em tubo de ensalo completando-se 1 ml com àgua destila da. Foram adicionados $1 \mathrm{~m} 1$ do reagente cupro-alcalino de SOMOGYI (1945) agitando as misturas e aquecendo em banho-maria a $100{ }^{\circ} \mathrm{C}$ durante 10 minutos. Após o resfriamento foi adicionado em cada tubo $1 \mathrm{~m} 1$ do reagente de Nelson, agitando-se bem e juntando com agitação, $4 \mathrm{~m} 1$ de àgua destilada.

A leitura foi feita a $530 \mathrm{~nm}$ em espectrofotômetro contra um branco preparado com àgua destilada em lugar da amostra.

o valor de absorbância foi interpolado em uma curva padrão de glucose.

0 teor de sacarose foi estinado pela diferença entre ART-AR, multiplicada Delo fator 0,95 que corresponde à molécula de ägua de hidrōlise.

3.2.2. Determinação dos compostos nitrogenádos

3.2.2.1. Proteina

\section{2 .2 .1 a) Extração}

A proteína foi extraỉda com solução de $\mathrm{NaOH} \quad 1 \mathrm{~N}$ a partir do sedimento que restou da preparação do extrato a 1 coólico para determinação de açücares redutores e N. $\alpha \mathrm{NH}_{2}$ soluve1. Depois de separadas por centrifugação a 6.000 rpm durante 10 minutos, o sedimento foi retomado em NaOH $1 \mathrm{~N}$ e novamente centrifugado. Os líquidos resultantes das duas extrações foram colocados em balão de $10 \mathrm{~m} 1$, completando-se o volume com o $\mathrm{NaOH} 1 \mathrm{~N}$, conforme descreve OCHOA-ALEJO (1980). 


\subsubsection{1.b) Quantificaçăo}

A proteína foi determinada pelo reagente de Fo1 in-Ciocalteau segundo LOWRY et alii (1951). Aos tubos de ensaio contendo $0,2 \mathrm{ml}$ de-extrato diluído cinco vezes $(0,5 \mathrm{~m} 1: 2 \mathrm{~m} 1$ de água) foi adicionado àgua destilada na quantidade suficiente para completar $0,4 \mathrm{ml}$ e $2 \mathrm{~m} 1$ do reativo de tartarato cuproalcalino, agitando-se rapidamente. Esperou-se 10 minutos e acrescentou-se com agitação $0,2 \mathrm{~m} 1$ do reagente de Folin-Ciocalteau I N. Após um perỉodo de 30. minutos, 1eu-se a $660 \mathrm{~nm}$, contra um branco cujo volume foi substituido por ägua destilada.

A concentração de proteína foi calculada utilizando uma curva padrão feita com a fração i da Albumina de soro bovino BSA (da Sigma Chemica 1 Company).

\subsubsection{Nitrogēnio solūvel em àlcool}

\subsubsection{2.a) Extração}

0 nitrogênio solúvel em ā1cool (N. $\left.\alpha \mathrm{NH}_{2}\right)$ foi ex traido a partir do extrato alcoólico, descrito por OCHOA-ALEJO (1980) que ćoi utilizado para a determinação de Açūcares Redutores.

\subsubsection{2.b) Quantificação}

0 N-solüvel foi determinado pelo mëtodo de KABAT e MAYER (1967). A mistura de reação consistiu em auecer a $85^{\circ} \mathrm{C}$ por 5 minutos, $0.2 \mathrm{ml}$ do extrato a $1 \mathrm{coó} 1 \mathrm{ico}$ com $0,4 \mathrm{~m} 1$ do reagente de ninidrina. Apos o resfriamento acrescentou-se 2 m1 de etano1 a $50 \%$ e procedeu-se a 1eitura a $570 \mathrm{~nm}$ em es- 
pectrofotômetro, contra um branco preparado com água destilada em lugar da amostra.

os valores de absorbância foram comparados com os valores de uma curva padrão de glicina.

\subsubsection{Nitrogênio total}

\section{2 .2 .3$. a) Extração}

0 N-total foi extraído atravēs da digestão sulfürica descrita por JØRGENSEN (1977).

Amostras de $50 \mathrm{mg}$ de material seco e pulverizado foram digeridas em balões Kjeldahl com 7 ml de uma mistura (solução digestora) contendo: $1 \mathrm{~g}$ de Selenito de Sódio Anidro; $21,39 \mathrm{~g}$ de $\mathrm{Na}_{2} \mathrm{SO}_{4} ; 4 \mathrm{~g}$ de $\mathrm{CuSO}_{4} \cdot{ }_{5} \mathrm{H}_{2} \mathrm{O} ; 200 \mathrm{ml}$ de $\mathrm{H}_{2} \mathrm{SO}_{4}$ concentrado e $175 \mathrm{~m} 1$ de àgua, até formação de vapores esbranquiçados que se transformam numa solução lỉmpida. Após o resfriamento, juntou-se ägua destilada pelas paredes do balão transferindo-se a mistura para o aparelho de destilação.

\subsubsection{3.b) Quantificação}

O N-total foi determinado pelo método de Kjeldahl. Pronedeu-se à destilação em meio alcalino, e a amônia desprendida foi captada por solução titulada de ácido em presença de um indicador. A porcentagem de nitrogênio foi calculada a par tir do volume de $\mathrm{H}_{2} \mathrm{SO}_{4} 0,1 \mathrm{~N}$ necessärio para titular a $\mathrm{NH}_{3}$ da amostra. 
3.2.3. Determinação do potássio

\author{
3.2.3.1. Extração
}

o K foi extraído através da digestão com o ácido perciórico de acordo com JØRGENSEN (1977): $250 \mathrm{mg}$ de material seco e moído foram transferidos para tubos de digestão de $75 \mathrm{~m} 1$. Adicionou-se com agitação $2,5 \mathrm{ml}$ de $\mathrm{HNO}_{3}$ concentrado, deixando-se à temperatura ambiente por uma noite. No dia seguinte os tubos foram colocados no bloco de digestão à tempera tura de $160^{\circ} \mathrm{C}$. Após 15 minutos aproximadamente, quándo os vapores começaram a subir e no fundo do tubo surgiu uma colocação clara (que significa evaporação da maior parte do HNO${ }_{3}$ ), os tubos foram retirados do bloco. Alíquotas de $0,7 \mathrm{~m} 1$ de ácido perciórico concentrado foram adicionadas aos tubos que foram recolocados a seguir no bloco à temperatura de $210^{\circ} \mathrm{C}$. A digestão ficou completa, 30 minutos depois com o surgimento de uma fumaça branca densa de $\mathrm{HC} 1 \mathrm{O}_{4} \cdot \mathrm{H}_{2} \mathrm{O}$ e a obtenção de uma solução incolor. Após o resfriamento, os extratos foram diluídos para $25 \mathrm{~m} 1$ com ägua destilada.

\title{
3.2.3.2. Quantificação
}

0 potássio foi determinado a partir dos extratos diluídos por espectrofotometria de absorção atômica segundo o método de ZAGATTO et alii (1981).

\subsection{Anālise enzimática}

\subsection{1.a) Preparação do extrato enzimātico}

Amostras de $200 \mathrm{mg}$ de material seco e pulveriza 
do, de segmentos da parte aerea de cana-de-açūcar, foram homogenizados em almofariz gelado na presença de nitrogênio 1íqu do com $10 \mathrm{~m} 1$ de tampão $\mathrm{Na}-\mathrm{Pi} 10 \mathrm{mM}$ pH 7,5 contendo Mercaptoetano 1 $1 \mathrm{mM} \mathrm{e} \mathrm{MnSO}_{4} 5 \mathrm{\mu M}$, de acordo com o método de PRADO et alii(1979) modificado. Após a homogeneização o extrato foi espremido em musseline e centrifugado a $13.000 \mathrm{rpm}$ durante 10 minutos. O pre cipitado foi descartado e o sobrenadante suspenso com o mesmo volume de $\left(\mathrm{NH}_{4}\right)_{2} \mathrm{SO}_{4}$ saturado. Depois de 24 horas em câmara fria centrifugou-se à 13.000 rpm durante 20 minutos e o sobre nadante foi descartado. O precipitado foi dissolvido em $1 \mathrm{~m} 1$ de água destilada e utilizado como fonte das enzimas.

\subsection{1.b) Determinação da atividade enzimātica}

As atividades de Invertase Ācida $(\mathrm{pH} 5,5)$ e In vertase Neutra $(\mathrm{pH} 7,1)$ foram determinadas peio método de $S A M-$ PIETRO et alii (1980) com algumas modificações. Todas as operações foram levadas a efeito à temperatura de $4^{\circ} \mathrm{C}$. A mistura de reação consistia de $200 \mu 1$ de sacarose $0,6 \mathrm{M} ; 50 \mu 1$ de. enzima diluída; 250 HI de tampão desejado: Tampão Acetato 0,2M pH 5,5 ou Tampão Fosfato 0,2 M pH 7,1 e água destilada para com pletar o volume de $1.000 \mu 1$. 0 sistema foi incubado a $37^{\circ} \mathrm{C}$ por 1 hora e a reação paralizada com 1 ml do reagente cuproa 1calino de SOMOGYI (1945). A quantidade de açúcares redutores liberado foi determinada pelo método descrito por NELSON (1944).

A atividade específica das enzimas foi expressa em mg de glucose formada por hora e por $200 \mathrm{mg}$ de matéria seca à $37^{\circ} \mathrm{C}$ - a pH 5,5 ou 7,1 . 


\section{RESULTADOS E DISCUSSÃO}

4.1. Interação "Potāssio/Crescimentọ/Atividade de Invertases"

Os níveis de $\mathrm{K}^{+}$na solução nutritiva afetaram marcadamente as plantas de cana-de-açūcar que apresentaram diferencas quanto ao aspecto morfológico e de desenvolvimento.

Com relação ao crescimento, as diferenças foram mais nitidas entre as plantas mantidas em baixo nível de $\mathrm{K}^{+}$(tra tamento $K_{1}$ ) que mostraram uma redução no tamanhó antes de apre sentarem sintomas visíveis de deficiência. 0 aparecimento destes, ocorreu aos 30 dias após o transplante,primeiramente nas folhas mais velhas e que concordam com aqueles descritos por DILLEWIJN (1952), HUMBERT (1963), HAAG (1965), SILVEIRA (1980) e MALAVOLTA (1982).

As plantas correspondentes aos demais tratamentos $\left(\mathrm{K}_{2}\right.$ e $\left.\mathrm{K}_{3}\right)$ não apresentaram qualquer sintoma de deficiência e tiveram um desenvolvimento ótimo de parte aérea,o que pode ser avaliado pela produção de matéria seca apresentada na Tabe $1 \mathrm{a} 2$. Apesar disso as plantas do tratamento $\mathrm{K}_{3}$ mostraram-se mais desenvolvidas quanto ao aspecto vegetativo do que as plantas do tratamento $\mathrm{K}_{2}$, consideradas "normais". Verifica-se por es = ses dados que o teor de matéria seca no segmento inferior da- 
quelas plantas $\left(K_{3}\right)$ é ligeiramente maior do que nos segmentos inferiores das plantas dos tratamentos $K_{1}$ e $K_{2}$ que estatisticamen te não diferiram entre si. A diferença, contudo, residiu na par te vegetativa, provavelmente devido-a diminuição dos internödios das plantas deficientes em potássio, o que determina uma diminuição da quantidade de matéria seca na região colmo/folha. ".

Estes resultados concordam com aqueles obtidos por GLOVER (1973) que atribuiu essa diferença ao maior tamanho do colmo em relação às outras partes da planta.

Através da Figura 3 verifica-se que, com exceção do segmento inferior das plantas do tratamento $\mathrm{K}_{3}$, o acúmulo de matéria seca pelos demais segmentos foi inicialmen te lenta até os 40 dias após o transplante, aumentando no perío. do de 40 a 60 dias.

Comparando a curva de crescimento dos segmentos da cana-de-açūcar com uma curva típica do crescimento de um vegetal (ambas expressas em função do peso seco), observa-se que houve concordância com a opinião de MAGALH̃̃ES (1979). Como. a cana-de-açúcar utilizada no presente ensaio possue apenas 90 dias de idade, observa-se que ficou bem caracterizado sómente duas fases da ontôgenese da planta: uma fase inicial, em que o crescimento foi lento e outro de rápido aumento de tamanho, em que os processos metabólicos dependentes da fotossintese se tra duzem por um rápido crescimento.

Observa-se ainda que o segmento inferior das plantas do tratamento $K_{3}$ parece ter atingido mais cedo do que os outros, o seu ponto máximo de crescimento (aquele em que teoricamente, a acumulação de matēria seca è máxima), indicando com isso precocidade. Esse resultado pode ser devido ao ex cesso de $\mathrm{K}^{+}$em contato com o sistema radicular, o que provoca ria maior absorção e translocação do ion para a parte aérea. 


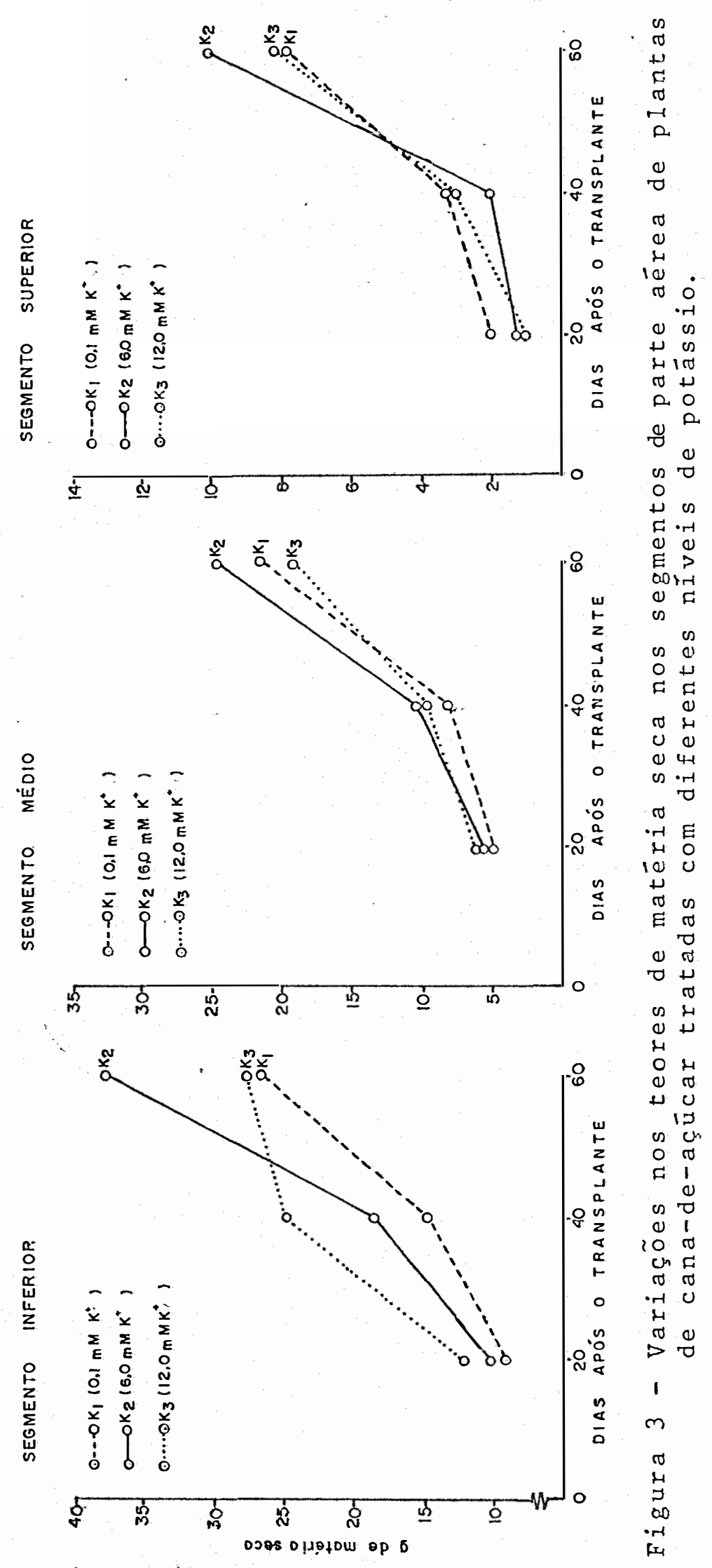


Através da Tabela 3 verifica-se que os teores de potássio nos segmentos das plantas desenvolvidas nas soluções nutritivas deficientes, foram significativamente inferiores aos obtidos nas soluções com niveis adequados de $\mathrm{K}^{+}$.

Os dados indicam que houve uma correlação positiva entre os niveis de $\mathrm{K}^{+}$do substrato e a quantidade de $\mathrm{K}$ que foi absorvida pela cana-de-açúcar. Segundo MALAVOLTA (1982) o acúmulo excessivo de K na célula é importante não apenas para o balanço hỉdrico da planta como também para ativação de enzimas. Todavia, os dados de atividade de invertase, principalmente de invertase ácida não concordam com essa afirmativa pois seus maiores valores foram detectados em condições de deficiência. Resultados semelhantes foram encontrados por HARTT (1934), que relata não ser o K essencial para a formação de invertase em cana-de-açúcar.

Através da Figura 4 observa-se que de modo geral, os diferentes segmentos mostraram uma tendência de diminuir o teor de $\mathrm{K}^{+}$com o aumento da idade da planta. Digno de nota é o elevado conteúdo de potássio que ocorreu nos tecidos da bainha/colmo (segmento inferior) das plantas dos tratamentos $\ddot{n}_{2}$ e $\mathrm{K}_{3}$, diminuindo à medida que se aproximava do ápice.

Esses resultados estão de acordo com BAVER (1960).

que estudando a composição química das partes da cana-de-açūcar,demonstrou que o teor de $\mathrm{K}^{+}$da baínha é maior do que o da região baínha/folha e que o conteúdo no colmo é muito maior do que nas folhas. Embora no presente ensaio não se tenha estudado tais partes isoladamente, nota-se que esses resultados estão relacionados com as partes das plantas correspondentes aos segmentos inferior e médio, o que explica a predominância de $\mathrm{K}^{+}$naqueles tecidos.

$$
\text { BURR et alii (1957) citando Burr e Tanimoto }
$$



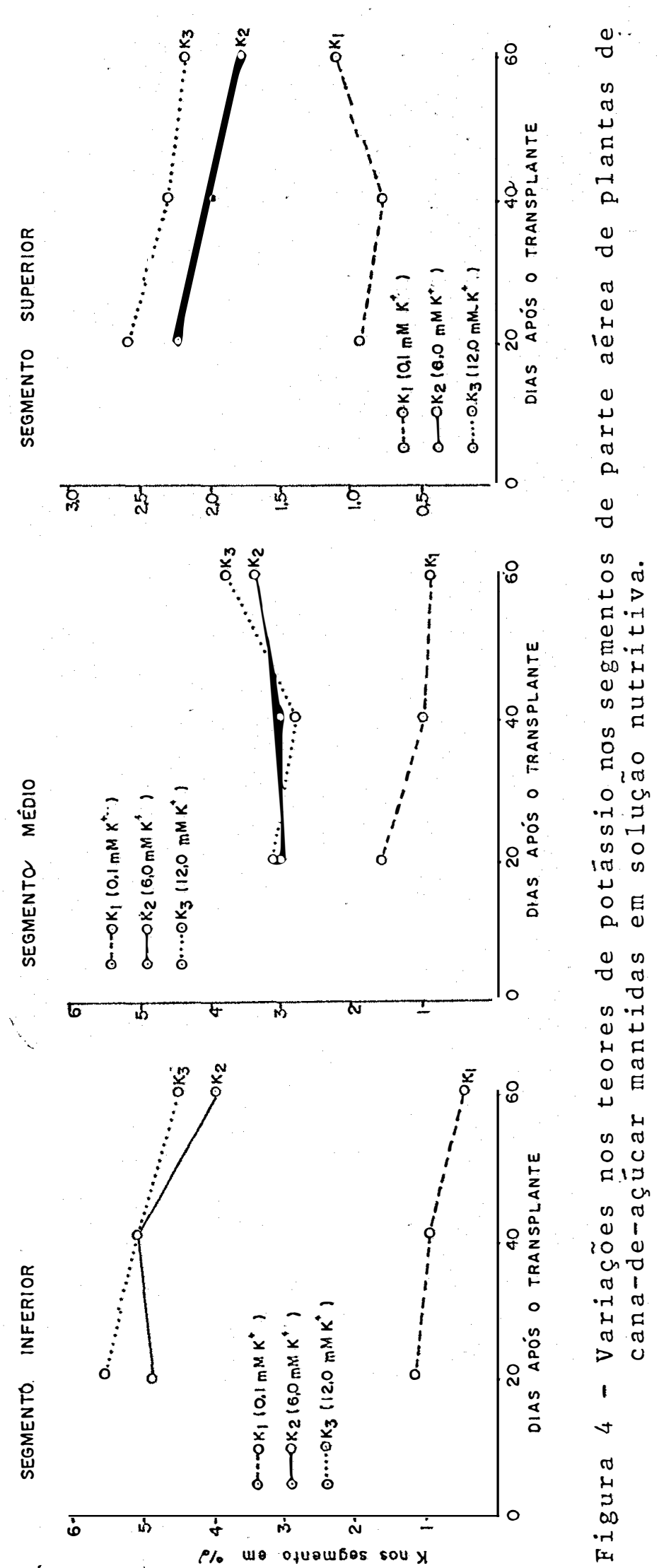
(1955) relatam que a concentração de potássio, tanto nas plantas bem supridas como nas deficientes, são mais evidentes em cana-de- açúcar adulta do que em tecidos de plantas jovens como é o caso do presente ensaio. Essa pode ser portanto uma das possíveis cau sas, dentro de certos 1 imites dos erros experimentais,das varia ções observadas em relação aos teores de $\mathrm{K}^{+}$e matéria seca.

A diminuição percentual observada na concentração foliar de $\mathrm{K}^{+}$das plantas do tratamento $\mathrm{K}_{2}$ e $\mathrm{K}_{3}$, pode ter sido resultado de uma diluição do íon a medida que a planta se desenvolve. Observa-se que na.região colmo/folha desses tra tamentos, o teor de $\mathrm{K}^{+}$aumentou, enquanto que na baínha/colmo, diminuiu. Isto poderia ser uma manifestação do efeito da translocação do íon da baînha/colmo para os órgãos vegetativos da planta, perdendo-se depois devido à 1 avagem do $\mathrm{K}^{+} \mathrm{da}$ parte aérea (MALAVOLTA, 1980).

E importante ressaltar que o efeito do $\mathrm{K}^{+} \mathrm{e}$ a $1-$ tamente significante e os dados mostram que ele estimula o crescimento de plantas jovens de cana-de-açūcar. Entretanto, quando se examina o comportamento do potássio dentro de cada segmento, verifica-se que não houve diferença significatí va em relação à produção de matêria seca denotando com isso que a idade da planta teve um efeito mais positivo sobre o crescimento do que os níveis de potássio. Esses resul tados estão de acordo com os apresentados por ALEXANDER (1964) em plantas jovens de cana-de-açūcar em condições de estres se de $\mathrm{NO}_{3}^{-}$e $\mathrm{K}^{+}$.

Uma boa parte dos trabalhos da literatura que descrevem os efeitos do potássio em vārios processos bioquímicos e fisiológicos, dão ênfase os seus efeitos benéficos sobre o crescimento e desenvolvimento vegetativo, incluindo divi são.celular, alongamento, diferenciação e outros processos ana bólicos dependentes da fotossintese e que se traduzem por um 
räpido crescimento. De acordo com BLANCHET et alii (1962) a participação do potássio no processo de fotossíntese faz com que esse íon participe decisivamente na taxa de crescimento es tando esta ação 1 igada à sua importância na retenção de água e portanto na turgescência das células vegetais.

MENGEL (1982) relata que a produção de matéria seca é menos sensível a um suprimento inadequado de potássio do que a turgescência dos tecidos jovens. Normalmente o potässio é "bombeado" em grandes quantidades nas células meriste máticas dotando-as de uma elevada turgescência que é um pré-requisito para a expansão celular e indiretamente para a divi são celular e crescimento. Esses resultados levam à sugestão de que os niveis de $\mathrm{K}^{+}$no presente ensaio exerceram efeito de natureza mais indireta, uma vez que as curvas de crescimento das plantas seguiram o padrão geral observado para outras culturas quase que totalmente independente da concentração empregada.

De um modo geral, tem sido observada uma corre1 ação entre taxa de crescimento e atividade de invertases. Estudos feitos por ROBINSON e BROWN, 1952; HELLEBUST e FORWARD, 1962; HATCH e GLASZIOU, 1963; SEITZ e LANG, 1968; MACLACHLAN et alii, 1970 e KAUFMAN et alii, 1973 mostram uma estreita cor relação entre tecidos de plantas em desenvolvimento e atividade de invertase ácida. Associado com a presença de alta atividade de invertase ácida parece estar à incapacidade de um tecido jovem em acumular sacarose.

Em colmo de cana-de-açúcar HAWKER e HATCH(1965) relatam que a invertase ācida solúvel é encontrada somente nos tecidos jovens, enquanto que nas partes mais maduras a enzima está ligada à parede celular. Assim, quando o crescimento ces sa espontaneamente ou sob influência de inibidores, a atividade de invertase diminui. Por outro lado, a invertase não é a- 
penas sintetizada mas é também degradada durante o crescimento, - que significa que ela está continuamente sofrendo mudanças, uma vez que, sua meia-vida em plantas de çana-de-açúcar é cer ca de apenas 2 horas conforme observações de Glasziou, citado por SEITZ e LANG (1968). Essas mudanças originam-se de cé lulas com um sistema de controle mais efetivo sobre o nỉvel de atividade enzimática e por consequência sobre o nível de utilização de açúcares que poderiam se originar somente pelas variações na intensidade de sỉntese da enzima. Os resultados indicam que a ação de invertase está correlacionada ao cresci mento e produção de açúcares. E desde que a produção de matéria seca em cana-de-açúear é derivada da sacarose a qual antes de ser metabolizada é hidrolisada por invertases, deve existir alguma relação entre ação dessas enzimas, aumento do teor de matéria seca e velocidade de crescimento celular (GAYLER e GLASZIOU, 1972).

\subsection{Interação Potāssio/Acūmulo de Açūcares/Atividade de Invertases}

O efeito dos níveis de potásio sobre os teores de açúcares nos segmentos de parte aérea de plantas jovens de cana-de-açücar são apresentados nas Tabelas 4,5 e 6 .

Verifica-se pela análise dos dados que ocorreram diferenças significativas entre os teores de açúcares (AR, ART e Sacarose) nos três níveis de potássio. observa-se também, que a presença de $\mathrm{K}^{+}$em concentração intermediária $(6,0 \mathrm{mM})$ promoveu aumento nos teores de sacarose e açūcares redutores totais (ART) e diminuição no conteúdo de açūcar redutor na re1 ação colmo/folha (segmento médio) que entretanto aumentou apös os 40 dias até o final do experimento. Verifica-se por outro 
1ado, que no tecido das folhas (segmento superior), o conteúdo de açúcares redutores foi bastante elevado nesse período. A partir daí,ocorreu uma diminuição desses açúcares, à medida que a sacarose aumentou. Esses resultados podem ser interpretados com base nas exigências do $\mathrm{K}^{+}$, em concentrações adequadas, nos estádios iniciais do desenvolvimento,uma vez que, a duração do presente ensaio coincidiu com a fase de crescimento linear (Figura 3). Sabe-se,pelos dados da literatura, que na fase inicial do desenvolvimento vegetativo, a cana-de-açúcar exige grandes quantidades de potássio para inúmeros processos bioquímicos endergônicos como a prōpria assimilação de $\mathrm{CO}_{2}$, sín tese de glicose, sacarose, proteỉnas, enzimas e outras biomolé culas de alto peso molecular, necessárias ao crescimento e de senvolvimento da planta.

Assim, a eleváda produção de açūcares redutores nas folhas é atribuída obviamente à maior atividade fotos sintética. A sua redução com o tempo e o consequente aumento de sacarose na região colmo/folha e colmo/baínha é devido provavelmente ao transporte desses assimilados da "fonte", que são. as folhas, para o "reservatório", que são todas as partes da planta que se utilizam dos fotossintetizados para o crescimento, metabolismo ou armazenamento (ALEXANDER, 1973; BERINGER, 1982 ).

HARTT et alii (1963) em estudos sobre a translo cação de sacarose ${ }^{14} \mathrm{C}$ em cana-de-açūcar demonstrou que esse açúcar, depois de ser formado nas folhas, passa rapidamente para o sistema condutor (nervuras secundárias) e daí para a nervura central seguindo depois para baínha em velocidade de $2,5 \mathrm{~cm} / \mathrm{m} \underline{i}$ nuto. Alcançado o colmo, sofre redistribuição interna,uma fra ção migrando para a parte superior e outra para as regiões inferiores. Nas raízes, caule e folhas é convertido em glicose e frutose que são utilizadas para o crescimento de paredes ce- 
lulares e protoplasma.

Segundo MENGEL (1982) a nutrição potássica favo rece o fornecimento de assimilados para o reservatório através da estimulação da fotossíntese e transporte do floema. Verifi ca-se pelos dados das Tabelas 4,5 e 6 que o conteúdo de açücares redutores totais, foi geralmente maior no segmento inferior (que corresponde aos tecidos da baínha/colmo) do que no segmento médio e superior.

Os estudos de MENGEL e KIRBY (1978) $\quad{ }^{14}{ }^{14} \mathrm{CO}_{2}$ mostraram que em plantas de cana-de-açúcar bem supridas de $\mathrm{K}^{+}$ ocorrem um acúmulo de açúcar na porção do colmo abaixo do ponto de inserção da folha que recebeu ${ }^{14} \mathrm{CO}_{2}$, sendo que os menores teores de açúcar foram constatados em pontos do caule,acima daquela folha. Parece que a presença do $\mathrm{K}^{+}$promoveu a mi gração de compostos radioativos em intensidades muitas vezes superiores às encontradas quando o íon estava deficiente. De acordo com autores citados por MALAVOLTA e CROCOMO (1982), o efeito do $\mathrm{K}^{+}$na migração de fotossintetados parece ser direta e muito provavelmente relacionado com o processo de fotofosforilação, pois quando o nível de $\mathrm{K}^{+} \bar{e}$ alto, pode ocorrer estímu 10 na produção de ATP, o qual por sua vez é necessārio para a migração de fotossintetados nos tubos condutores.

Em termos de deficiência de potássio(Nível K 1 ), observa-se que a redução de sua concentração de 6,0 para $0,1 \mathrm{mM}$ resultou em grande aumento de açucares redutores totais(ART), açūcares redutores (AR) e sacarose,cujos valores foram signifi cantemente mais altos do que os constatados em plantas normais (Níve $1 \mathrm{~K}_{2}$ ) e supridas com excesso de $\mathrm{K}^{+}$(Nivel $\mathrm{K}_{3}$ ).

Pela anāiise da Figura 5 observam-se as varia ções nos teores de açúcares redutores durante o período em que durou o experimento. Verifica-se que no segmento inferior (baí 


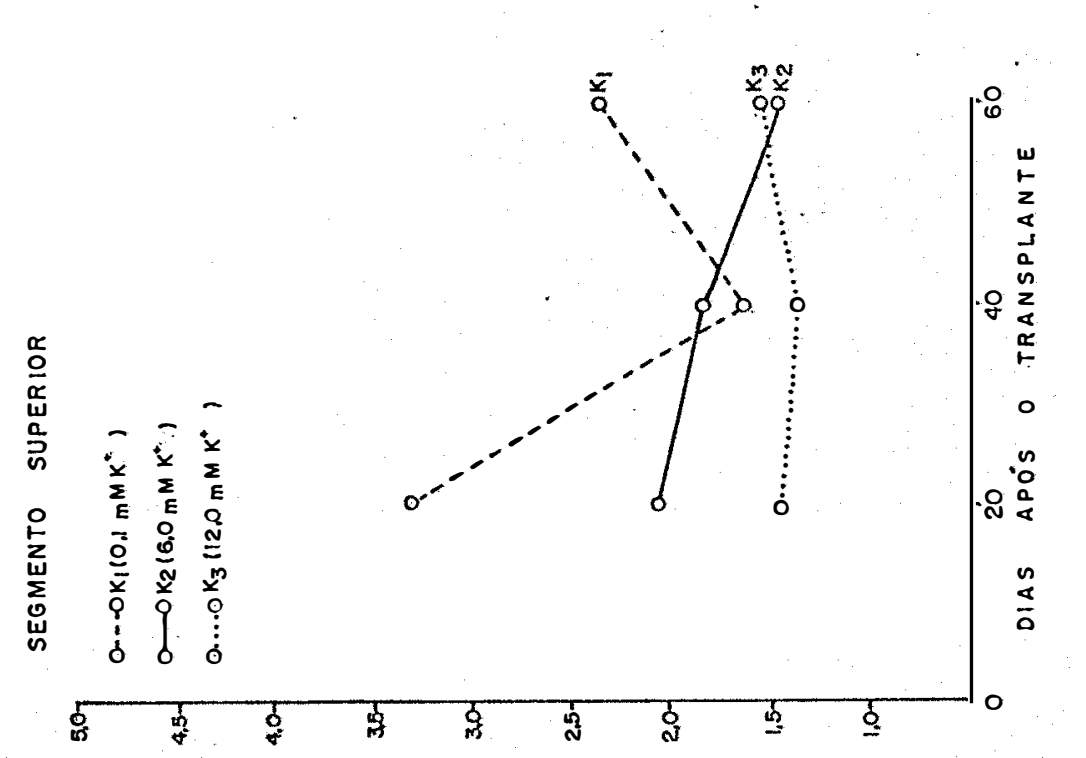

단.

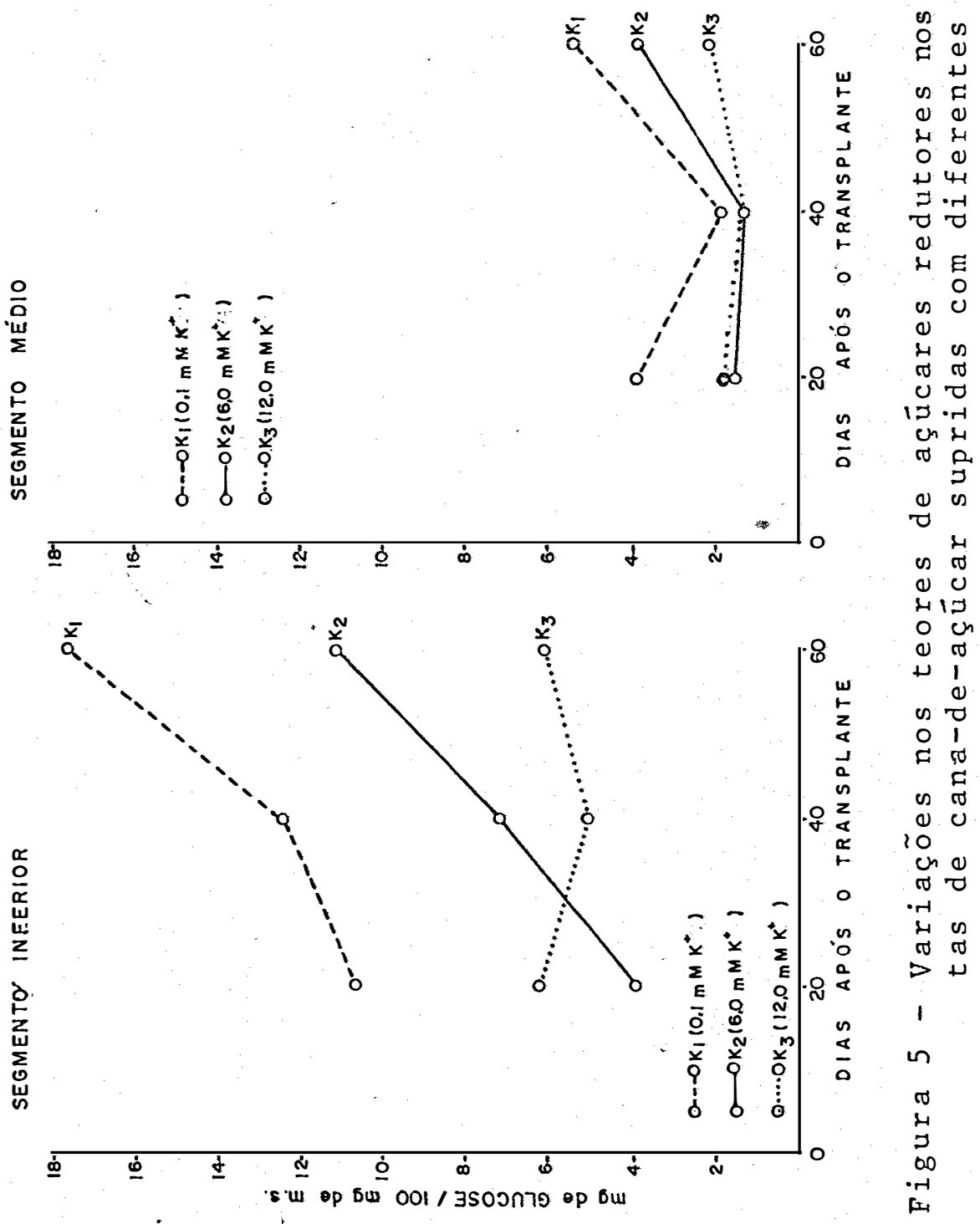


nha/colmo) o acúmulo de açücares redutores foi proporcional ao tempo, o que pode ser explicado possivelmente pela presença de altos níveis de invertase ácida presentes nos estádios iniciais de desenvolvimento e que foram encontradas na bainha de folhas de cana-de-açūcar por SAMPIETRO et alii (1980).

Diferenças notāveis foram constatadas entre os nîveis de açūcares redutores (AR) nos segmentos médio e superior nos sucessivos estádios de desenvolvimento: aos 20 dias ocorreu uma acentuada elevação que foi diminuindo gradualmente até os 40 dias,para depois sofrer um novo aumento até os 60 dias.

Esses resultados sugerem que a deficiência de $\mathrm{K}^{+}$exerce profunda influência nas transformações de hexoses o que pode estar possivelmente relacionado com as mudanças na velocidade de transporte, utilização ou formação de glucose e frutose elou formação de enzimas.

Nas plantas supridas com excesso de $\mathrm{K}^{+}$(Tratamento $\mathrm{K}_{3}$ ) um fato interessante que chamou a atenção, foi a diminuição gradativa dos açūcares redutores totais no tecido das folhas (Figura 6), sugerindo uma elevada degradação de açūcares provavelmente pela respiração. Esses resultados indicam que a cana-de-açūcar, mais do que a maioria das outras espëcies vegetais, tem necessidade de metabolizar glucose durante seus primeiros meses de desenvolvimento. ( $A L E X A N D E R, 1965 a$ ).

GLOVER (1973) estudando a degradação dos açūcares armazenados no colmo pela respiração, chegou à conclusão de que a perda de carboidrato depende da idade da cana e da proporção entre as folhas, podendo variar de $20 \%$ em plantas jovens crescendo ativamente. Verifica-se pelos resultados obti dos que o conteúdo de açūcares nos tecidos da baỉnha/colmo (segmen to inferior) foi em todos os casos maior do que o conteúdo nos 

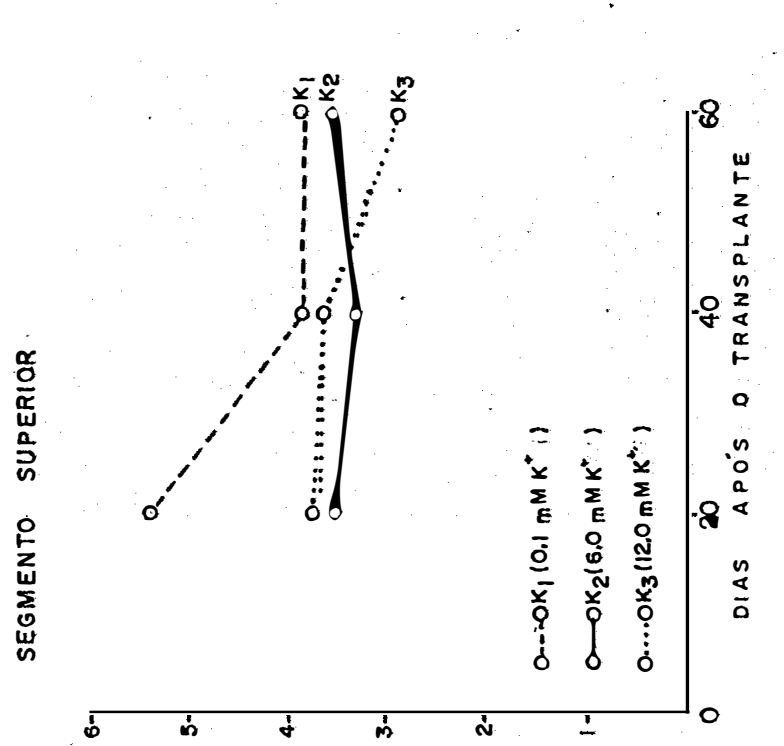

故.

.50.

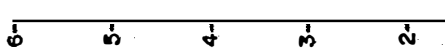

(1)

- वृ

os

$\begin{array}{ll}0 & 0 \\ 0 & 0 \\ 0 & 0\end{array}$

E 0

Eir

an 5

is o

क ث)

O

(

F世

舟

$\begin{array}{rrr} & E \\ -\pi & 0 \\ -\pi & 0\end{array}$

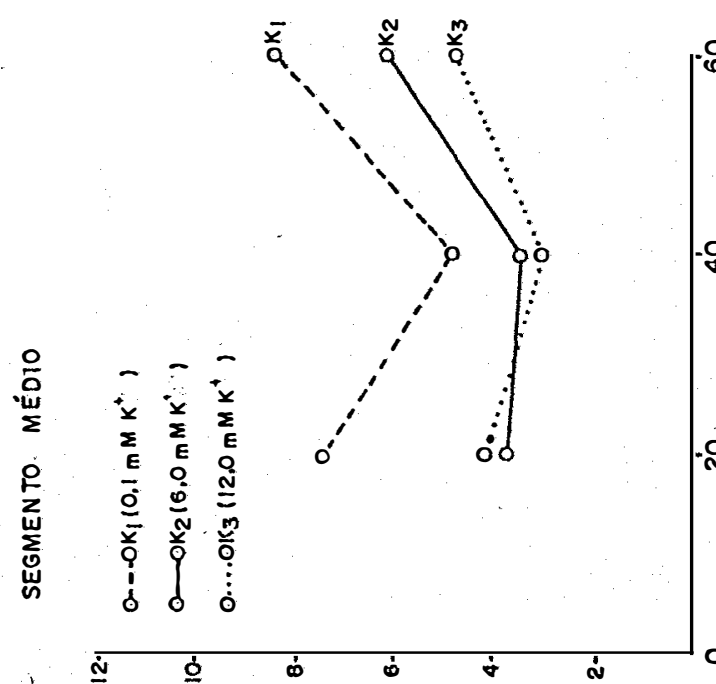

$\begin{aligned}+ & 0 \\ 0 & \pi\end{aligned}$

- $\theta$

แ क मे

$\begin{array}{lll}2 & 0 & 0 \\ 2 & 4 & 7 \\ 5 & 0 & 0\end{array}$

a

o

$\begin{array}{lll}0 & 0 \\ 0 & 0 & 0 \\ 0 & 0 & 0\end{array}$

- वा7

- $\quad 0$

$\because \begin{array}{lll}0 & 0 & 1 \\ 0 & 0 & 0\end{array}$

-

(4) $\quad 01$

近皆
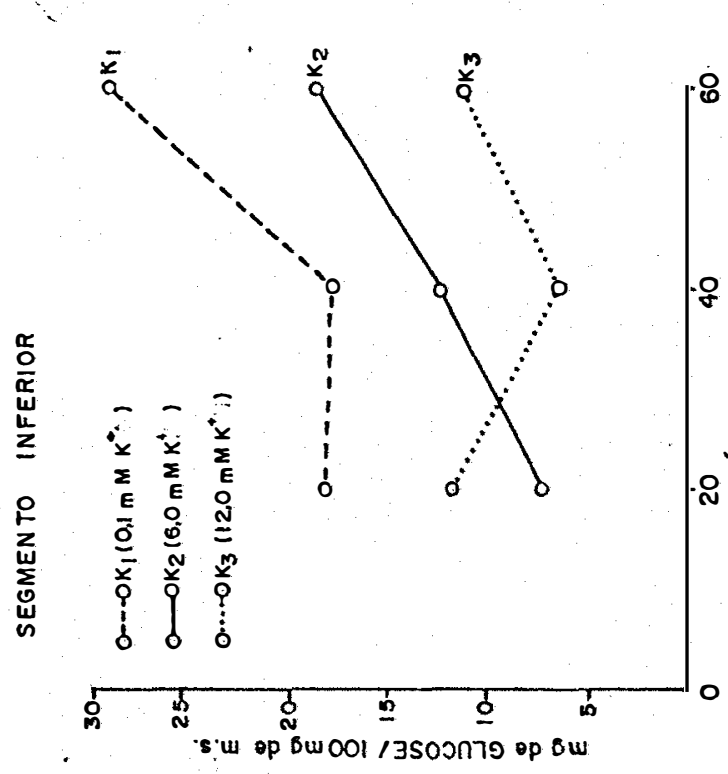

0

ठ

$\begin{array}{ll}0 & \infty \\ 0 & 0\end{array}$

넝

(1)

o $\overrightarrow{8}$

잉

is

in 10

ब10

- $\rightarrow \pi$

$\begin{array}{lll}0 & 4 \\ 0 & 0 & 0 \\ 0 & 0 & 0\end{array}$

a 1

6

$\infty$
2
0
00
$-\pi$
12 
tecidos da região colmo/folha e das folhas, independente do ni vel de $\mathrm{K}^{+}$. Esse comportamento pode ser devido ao teor mais elevado de matéria seca do segmento inferior. Aliās, GLOVER (1973) relata que proporcionalmente a matéria seca, as folhas respiram mais rapidamente que o colmo. Entretanto, como a matéria seca do colmo é muito maior, ocorre aí a maior perda, de carboidratos.

Acredita-se que as diferenças encontradas entre os tratamentos e os teores de açucares estejam relacionadas ao desenvolvimento ontogenético da planta. Assim,quando se comparam os resultados obtidos pelas plantas cultivadas em deficiên cia de $\mathrm{K}^{+}$e as supridas com altos níveis, verifica-se que o ín atua de maneira decisiva no metabolismo de açúcares de plantas de cana em desenvolvimento ativo. Por outro lado, as varia ções nos teores de açúcares nos três níveis de $\mathrm{K}^{+}$sugerem que as concentrações mais baixas $\left(K_{1}\right)$ parecem ter influência mais direta sobre o metabolismo de açūcares do que sobre o mecanismo de migração de açúcares em plantas jovens. Esses resultados estão de acordo com ALEXANDER (1964) e Steinberg, citado por PIRSON (1955).

Apesar do grande volume de trabalhos da literatura que descrevem os efeitos benéficos do $\mathrm{K}^{+}$em värios processos bioquímicos relacionados ao metabolismo celular de plantas de cana-de-açúcar e apesar de sua importância como um elemento essencial dara a obtenção de elevados teores de sacarose (SAMUELS e LANDRAU, 1952; SAMUELS et alii, 1952 e 1956), ainda não estão bem definidas em que fases do metabolismo do açūcares o potássio atua.

Em termos de sacarose, observa-se pela Figura 7 que as plantas cultivadas em condições de deficiência de potássio ( $T r a t a m e n t o K_{1}$ ) apresentaram baixos teores de sacaro se no segmento médio (colmo/folha) e segmento superior (folhas). 


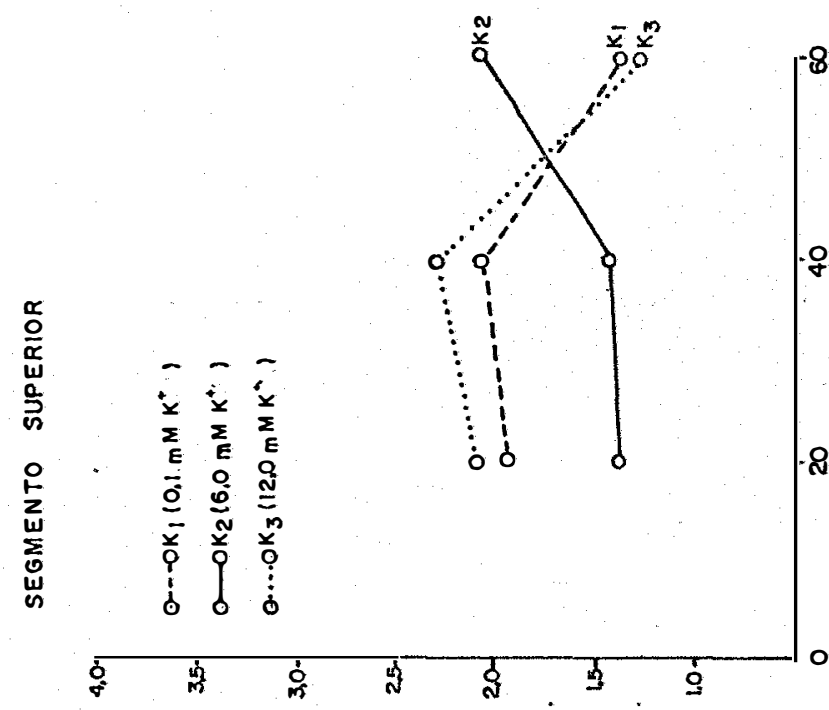

.52.

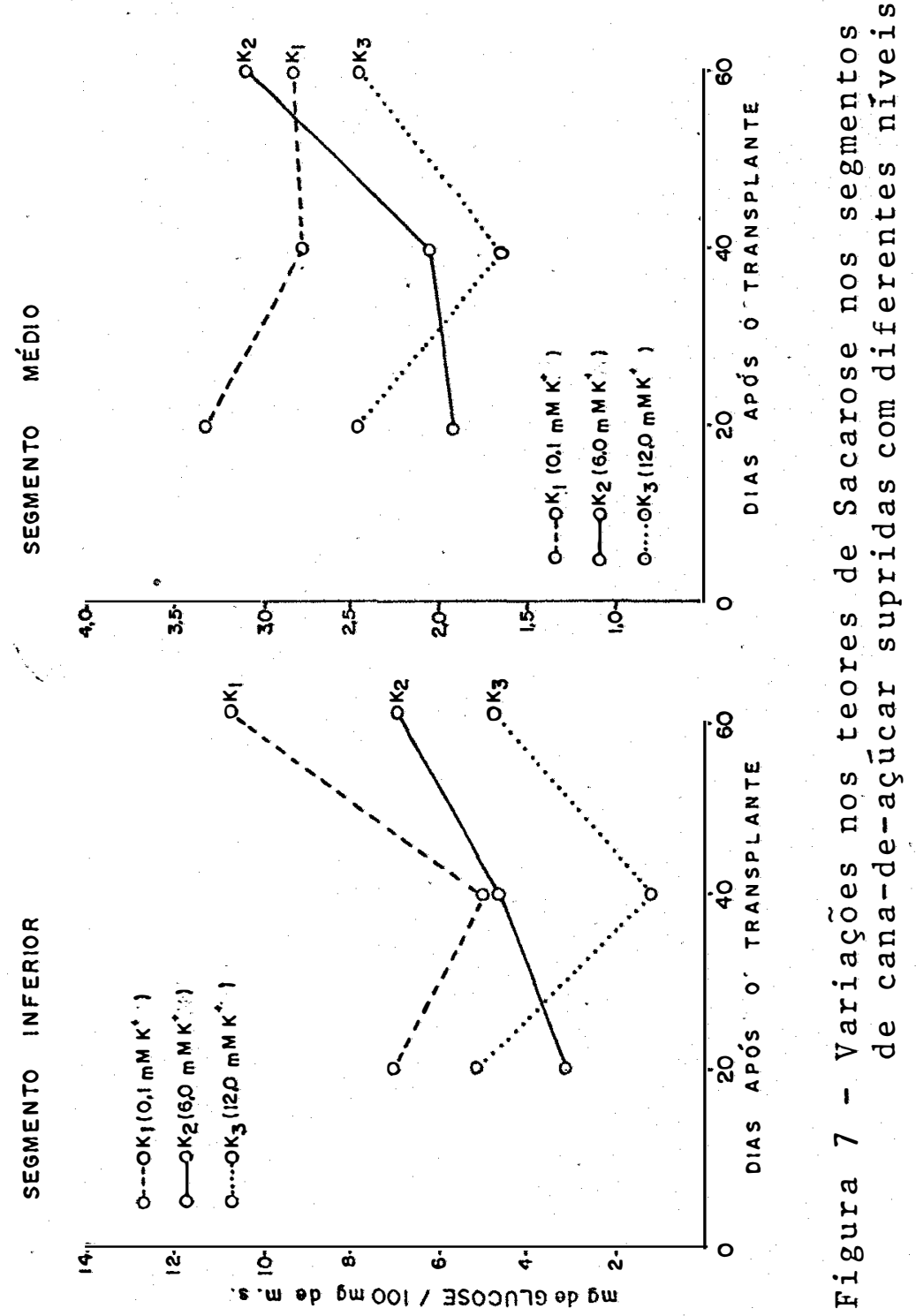


Nas plantas normais (Tratamento $\mathrm{K}_{2}$ ) o teor de sacarose nos três segmentos (inferior, médio e superior) aumen tou gradualmente com o tempo, emborá nos doị ūitimos, o acúmu1o de sacarose tenha se processado lentamente até aproximadamente 40 dias. Esses dados são concordantes com os resultados de matéria seca,visto que esta é derivada da sacarose conforme os relatos de GAYLER e GLASZIOU (1972).

Nas plantas do tratamento $\mathrm{K}_{3}$ observa-se que, en quanto nos dois ültimos segmentos (médio e inferior) o teor de sacarose diminuia até 40 dias para depois aumentar, no segmento superior, ocorreu exatamente o contrário; o conteúdo de sacarose aumentou 1 igeiramente até os 40 dias e depois disso diminuiu.

Estas variações nos tëores de sacarose no colmo foram observadas também por.SUZUKI (1982) e embora consideradas normais, podem ser devidas não apenas a metodologia utilizada como afirma o autor, mas à pouca idade ontogenética das plantas do presente estudo.

Há uma divergência de opiniões quanto ao acümu10 de sacarose pela cana-de-açúcar. em função da idade. Embora muitos afirmem que a cana-de-açucar é uma planta que acumula sacarose no colmo maduro (HATCH et a $i$ i, 1963) outros como ALEXANDER (1973) relatam que o acúmulo de sacarose ocorre tanto em tecidos imaturos como em tecidos adultos.

Em tecidos imaturos essa sacarose previamente formada pelas sintetases de sacarose, é rapidamente hidrolisada pela atividade de invertase ácida vacuolar que começa a desaparecer logo que termina a elongação celular. A maturação do colmo envolve uma elevação do nível de 2 hexoses,glicose e fru tose (cerca de $0,05 \%$ do peso fresco) e um concomitante aumento de aproximadamente $20 \%$ do peso fresco em sacarose (GAYLER e 
GLASZIOU, 1972). Entretanto, como o principal objetivo do pre sente ensaio foi o de acompanhar o efeito do $\mathrm{K}^{+}$sobre a atividade de invertases relacionadas com o metabolismo de açúcares, é importante ressaltar o efeito da deficiência potássica sobre o conteúdo de sacarose e açúcares redutores.

observa-se pelos dados, que na primeira amostragem ( 20 dias) quando a deficiência erá branda, as plantas de tratamento $K_{1}$ apresentavam maiores teores de açúcares do que as plantas do tratamento $K_{2}$, consideradas normais. Apesar do grande acúmulo de sacarose apresentado pelas plantas deficientes,observa-se também, que nas plantas do tratamento $K_{2}$ e $K_{3}$ o conteúdo de sacarose foi sempre menor do que o de açúcar redutor. Esses resiltados sugerem que altas concentrações de in vertase estão presentes em tecidos jovens de cana-de-açúcar(SAMPIETRO et alii, 1980) e que na deficiência de potássio essa con centração é maior, o que coñcorda com HARTT (1934).

Em relação ao mais baixo teor de sacarose associado com o elevado teor de açúcares redutores em plantas defí cientes, resultados semelhantes foram obtidos, por ALEXANDER (1964), SILVEIRA (1980) e SUZUKI (1982).

ALEXANDER (1964) mostrou que os açúcares redutores totais foram se acumulando tanto no tecido da folha como no da baínha em resposta ao decréscimo de $\mathrm{K}^{+}$e que a glicose foi o principal açúcar responsável por esse aumento. Houve também concordância quanto a acumulação de açúcar no final do ensaio. Apesar das semelhanças, verificam-se algumas dí vergências nos resultados, o que se deve provavelmente ao fato de que neste trabalho as plantas foram mantidas nos tratamentos apenas 60 dias enquanto que no trabalho daqueles autores as plantas permaneceram de 3 a 7 meses. As condições de clima, cultivares diferentes e variabilidade genética são fatores que devem ser considerados. 


\subsection{Interação "Potássio/Compostos Nitrogenados/Atividade de Invertases"}

As Tabelas 7,8 e 9 mostram o efeito dos níveis de $\mathrm{K}^{+}$na quantidade de compostos nitrogenados dos segmentos da parte aérea das plantas em função da idade (dias após o transplante para as soluções nutritivas).

Através da Tabela 7 observa-se que o nível mais baixo de $\mathrm{K}^{+}\left(\mathrm{K}_{3}\right)$ na solução nutritiva mostrou uma tendência de aumentar os teores de proteína e $\mathrm{N}-\alpha \mathrm{NH}_{2}$ solúvel e diminuir o total no segmento superior das plantas deficientes quando comparadas às normais (do níve $1 \mathrm{~K}_{2}$ ).

Os dados da Tabe 1 a 8 evidericiam que aos 40 dias houve uma tendência contrāria: o teor das três frações nitroge nadas (N-total, $\mathrm{N}-\mathrm{aNH}_{2}$ e proteína) foi menor no segmento superior das plantas $K_{1}$ do que nos das plantas $K_{2}$. Já no final do experimento ( $T a b e l a 9$ ) as plantas deficientes em comparação com as plantas normais mostraram uma tendência para aumentar os teores de $\mathrm{N}-\alpha \mathrm{NH}_{2}$ e $\mathrm{N}-\mathrm{tota} 1$ e diminuir o teor de proteína principalmente no segmento superior que se diferenciou dos demais.

Confrontando os dados encontrados no presente ensaio com aqueles relatados por SUZUKI (1982), ALEXANDER (1964) e HARTT (1934) que utilizaram cana, de idade diferente e separação das diferentes partes da planta, observa-se que a concordância dos dados é parcial. Pode-se notar uma grande varia ção de resultados o que pode ter sido provocado pela análise conjunta de folha mais colmo (segmento médio) e de colmo mais baínha (segmento inferior).

Essas variações contrariam os resultados relata dos por HARTT (1934), HUWBERT (1963) : e ALEXANDER, 1964), 
que observaram uma tendência geral de aumentar os teores de pro teinas, $\mathrm{N}-$ total e $\mathrm{N}-\alpha \mathrm{NH}_{2}$ solúvel nas folhas de cana-de-açúcar com deficiência de potássio.

No segmento inferior observa-se que as varia ções ocorreram principalmente com os teores de proteínas e N-total, que na. deficiência apresentaram durante o ensaio uma tendência de diminuir muito mais do que as plantas normais.

Esses resultados podem estar relacionados ao maior acúmulo de carboidratos no. segmento inferior das plantas deficientes o que leva à sugestão de que a causa principal desse acúmulo pode ter sido uma alteração na síntese de "proteínas o que pode estar correlacionado à atividade de invertase. Observou-se que no presente ensaio o segmento inferior das plantas do tratamento $K_{1}$, apresentou níveis mais altos de atividade de invertase ácida do que as plantas do tratamento $\mathrm{K}_{2}$, o que provavelmente provocou o acúmulo de açúcares totais nessa região da parte aérea.

Evidencia-se também pelos resultados obtidos, que nas condições do ensaio, as alterações na sintese de proteínas são indicadas indiretamente pela redução do crescimento das plantas deficientes e diretamente pelas determinações do nitrogênio o que concorda com as observações relatadas por HARTT (1934).

Em relação as plantas dos tratamentos $K_{2}$ e $K_{3}$ observa-se pelos dados das Tabelas 7,8 e 9 que o segmento mé dio e superior apresentaram uma tendência de aumentar o teor de proteina com o tempo. Esse aumento pode ser atribuído a uma rápida polimerização de aminoācidos, o que vem explicar o efei to do $\mathrm{K}^{+}$como fator essencial no processo de formação dessa ma cromolécula para suprir as exigências da fase de crescimento. 
Quanto aos teores de $\mathrm{N}-\mathrm{total}$ e $\mathrm{N}-\alpha \mathrm{NH}_{2}$ dos segmentos médio e superior dessas plantas $\left(K_{2}\right.$ e $\left.K_{3}\right)$ observa-se que a tendência geral foi de diminuir com o tempo embora os teores de $\mathrm{N}-\alpha \mathrm{NH}_{2}$ tenham sofrido uma elevação aos 40 dias. 0 decréscimo no conteúdo dessas 2 frações pode ter sido provocado por uma maior utilização de aminoácidos evitando com isso que eles se jam acumulados.

Ressalta-se ainda os diferentes resultados obti dos para o teor de proteínas no segmento inferior; enquanto que o teor de proteínas das plantas $K_{2}$ aumentou acentuadamente o das plantas $K_{3}$ diminuiu e o das plantas $K_{1}$ manteve-se praticamente constante durante todo o período considerado.

Essas diferenças encontradas podem ser atribuí das às frequentes mudanças destas frações durante o desenvolvi mento. A idade fisiológica da planta pode ser a mais satisfató ria base de comparação, entretanto é perigoso fazer tal afirma tiva,uma vez que às plantas foram fornecidas, diferentes quantidades de potássio. Contudo, a despeito destas limitações, os resultados do presente ensaio mostram que a nutrição potássica afetou consideravelmente a distribuição das frações nitrogena das individuais.

Analisando-se a Figura 8 observa-se que o teor. de N-total se eleva no segmento inferior (regiãobaỉnha/colmo) em todos os tratamentos, sendo que o aumento foi gradual no nível intermediārio de $\mathrm{K}^{+}$(Nivel $\mathrm{K}_{2}$ ). Nos níveis $\mathrm{K}_{1}$ e $\mathrm{K}_{3}$ a percenta gem de distribuição do $N$ se tornou praticamente constante a par tir dos $40 \mathrm{dias}$.

Nos segmentos médio e superior, ao conträrio do que ocorreu no segmento inferior, observou-se que o teor de $\mathrm{N}$-total mostrou uma tendência de diminuir ao longo do experi mento sobretudo nos níveis mais elevados de potásio. 


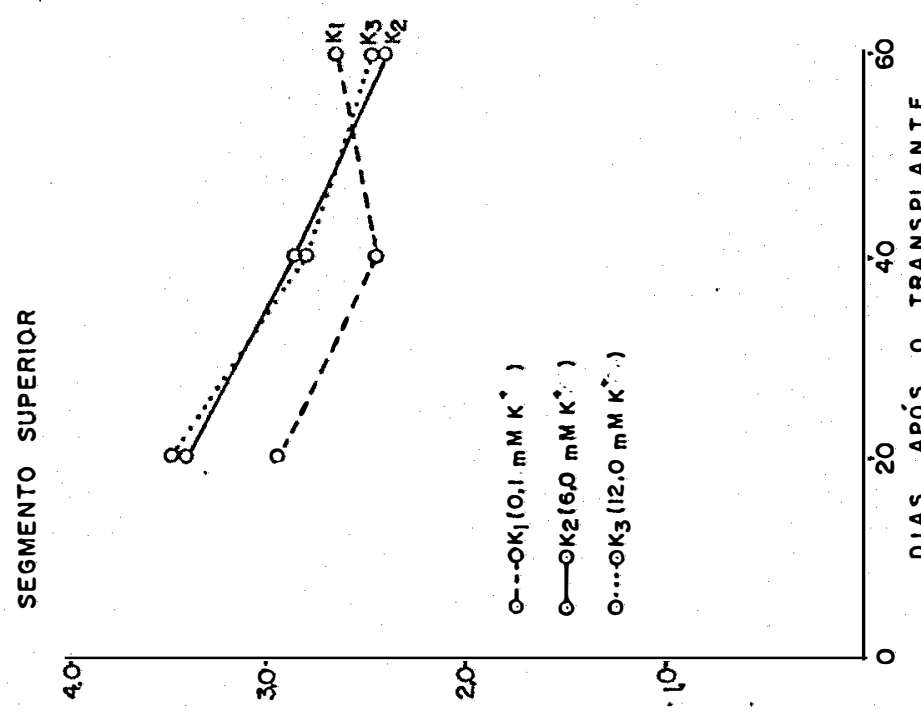

.58

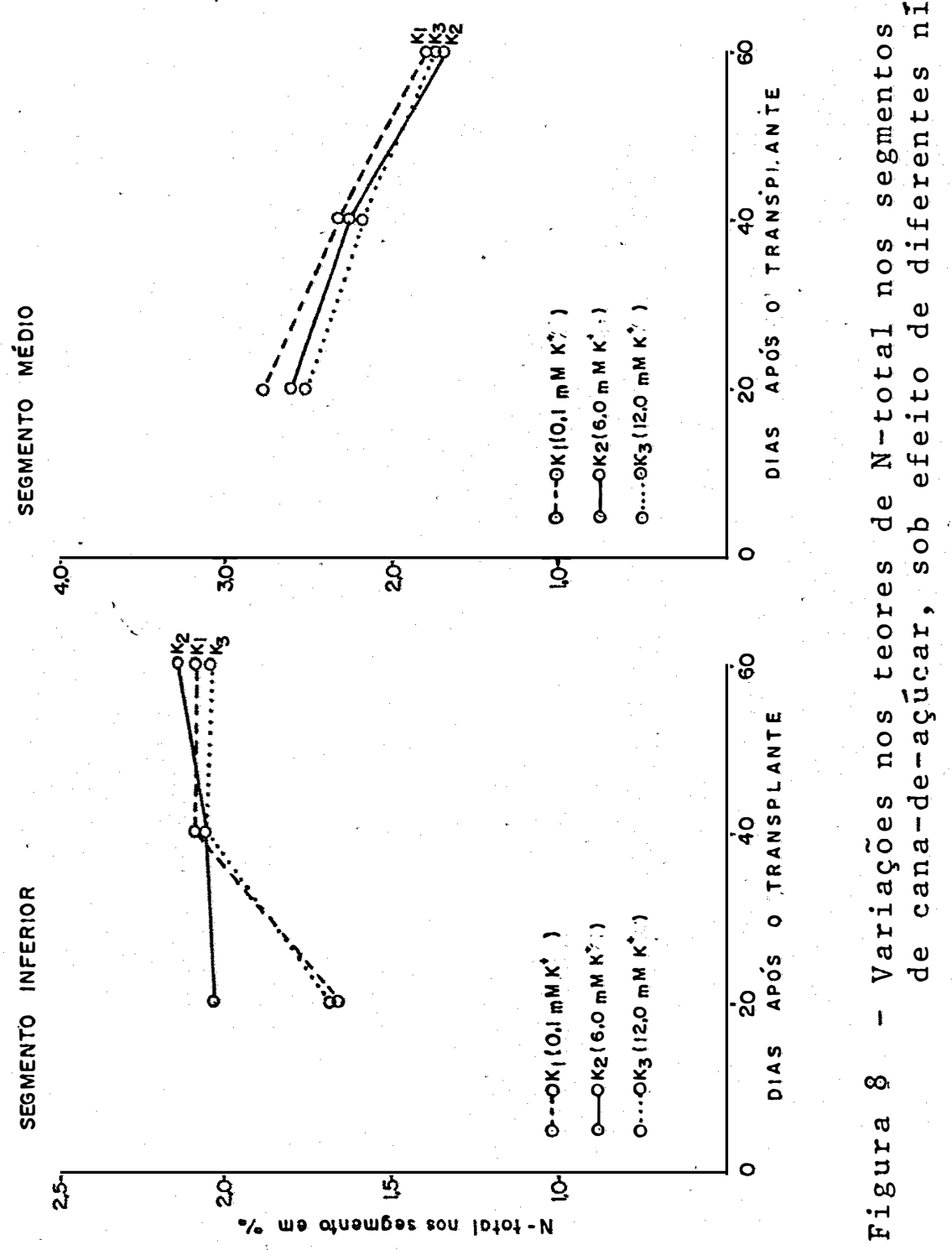


No nível mais baixo, essa diminuição se processou até os 40 dias, sofrendo a seguir uma acentuada elevação.

Os dados revelam que o comportamento do $\mathrm{K}^{+}$em relação aos teores de N-total foi significativamente diferente dentro de cada segmento, indicando uma interação significa tiva entre os níveis de $K$ e os segmentos de parte aérea. Obsex va-se que os maiores valores de N-total foram constatados no segmento superior seguindo em ordem decrescente o segmento médio e inferior. E também importante observar que a ordem: segmento superior > segmento médio > segmento inferior foi cons tatada apenas aos 20 e $40 \mathrm{dias}$. Aos $60 \mathrm{dias,}$ menores teores de $\mathrm{N}$-total foram constatados no segmento médio, não ocorrendo em diferenças entre os teores de nitrogênio do segmento superior e inferior.

0 fato de que o teor de N-total diminue no col mo e nas folhas a medida que se elevam os teores de $\mathrm{K}^{+}$(nível $\mathrm{K}_{2}$ e $\mathrm{K}_{3}$ ) pode estar relacionado com a utilização de aminoácidos na sintese de proteína, diminuindo comisso o conteúdo de aminoácidos 1ivres.

Muitos autores como KARMANENZO (1968), BARKER $e$ BRASFIELD (1963), HSIAO et alii (1970) tem estudado o efeito da nutrição potássica sobre a percentagem de distribuição do $N$ em plantas incluindo o N-total livre ou ligado aos aminoácidos, nitrogênio não protéico, N-amoniacal, N-cítrico, amidas, aminas, etc.

Quanto ao efeito da deficiência de potássio sobre a fração nitrogenada, a principal observação foi a acumu lação de N-total nas folhas (segmento superior) e na região colmo/folha (segmento médio) sugerindo uma possível acumulação de amônia e amida nessas regiões da planta.

os resultados obtidos no presente estudo são con 
cordantes com a literatura, no sentido de que as plantas supri das com baixo nível de potássio apresentarem maior teor de N-total nas folhas e no colmo. Todavia, ao comparar os resul tados dos níveis $K_{2}$ e $K_{3}$ observa-se uma certa semelhança entre os dados, indicando que altos níveis de $\mathrm{K}^{+}$capacitam as plantas a utilizarem grandes proporções de $N$ sob forma de amônia. Isto é evidente pelós decréscimos no conteúdo de $\mathrm{N}-\alpha-\mathrm{NH}_{2}$ solúvel (aminoācidos livres, amidas, peptídeos, etc.), quando o suprimento de $\mathrm{K}^{+}$na solução nutritiva está em condições adequadas, o que pode ser observado pela análise da Figura 9. Verifica-se que o efeito gerál do $\mathrm{K}^{+}$, exceto quando fornecido em concentra ções excessivas $\left(\mathrm{K}_{3}\right)$, foi o de aumentar os teores de $\mathrm{N}-\alpha-\mathrm{NH}_{2}$ so lúvel, resultando com isso um acúmulo de uma ampla série de metabólitos (aminoácidos livres e ligados, a midas, aminas, uréia, ureídos, purinas, etc...) principalmente nos tecidos da baínha/colmo (segmento inferior) embora tenha ocorrido um ligeiro aumento nas folhas (segmento superior) das plantas de cana-de- açücar deficiente.

No segmento inferior entretanto, ocorreu um fato interessante: foram constatados elevados valores de N-soluvel não apenas nas plantas deficientes como também quando as concentrações de $\mathrm{K}^{+}$estavam em nível intermediārio $\left(\mathrm{K}_{2}\right)$ ọu mui to alta $\left(\mathrm{K}_{3}\right)$. No nível mais elevado ocorreu inicialmente uma diminuição brusca que foi compensada por uma elevação acentua. da a partir dos 40 dias. 0 mesmo fato não se verificou no segmento médio e superior nos quais as variaçöes dos efeitos das doses crescentes de $\mathrm{K}^{+}$não foram estatisticamente diferentes. A interpretação para as acentuadas variações observadas no segmen to inferior é que provavelmente altos níveis de $\mathrm{K}^{+}$aumentam a utilização de aminoácidos na síntese de proteínas, diminuindo como consequência o conteúdo total de aminoácidos livres. A uti lização de aminoácidos para a sintese de proteínas alcança maio res proporções no processo de transaminação onde se formam maio 


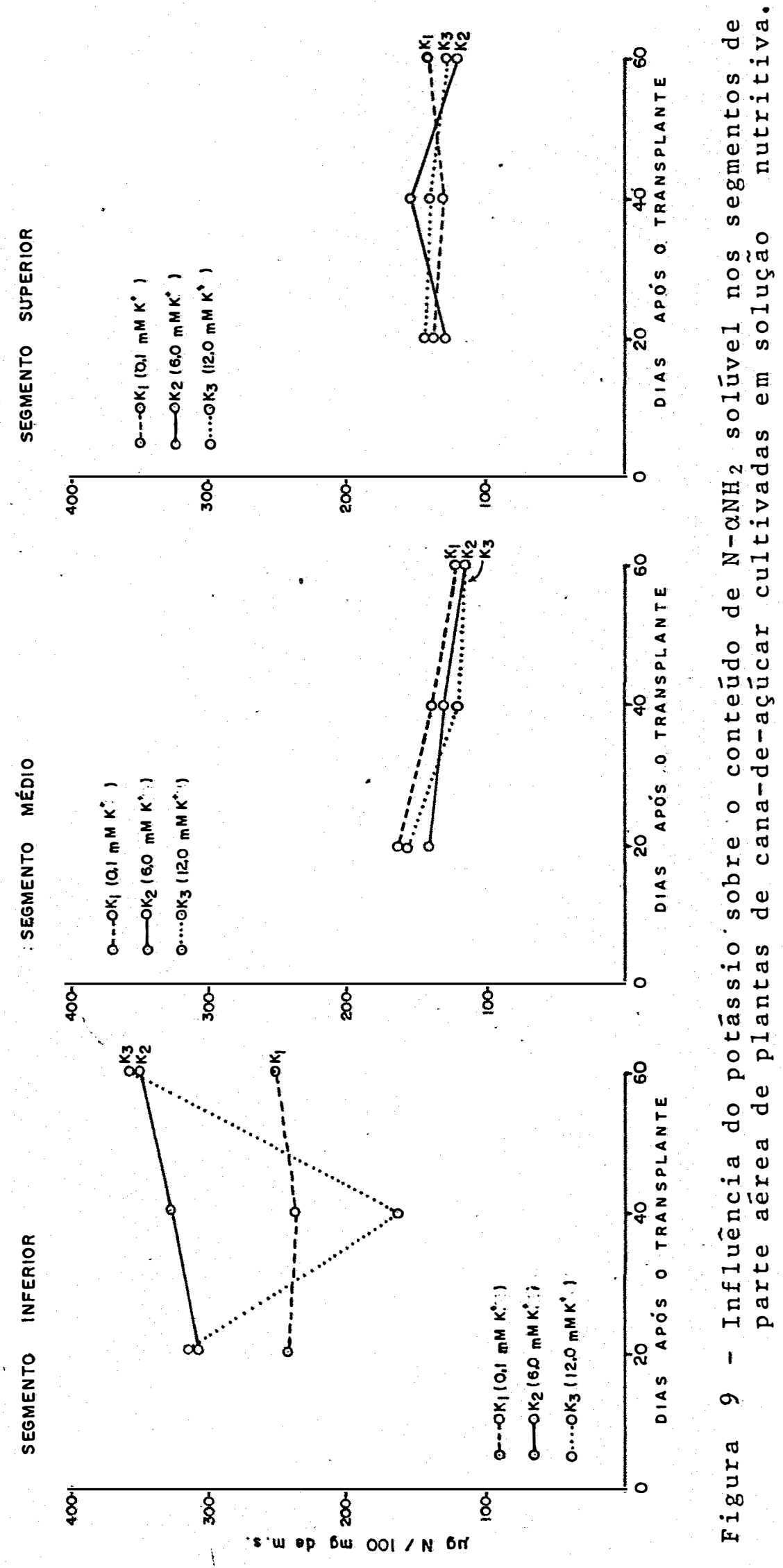


res quantidades de ācido aspārtico e ācido glutâmico (BARKER e BRADFIELD, 1963) que são "aminoácidos de origem", sintetizados a partir de carboidratos fornecidos através do processo de res piração (CROCOMO, 1979 ).

Apesar da grande maioria dos trabalhos de 1 ite ratura afirmarem que acumulação de carboidratos e de compos tos nitrogenados solúveis estão associados a uma diminuição da sintese proteíca em condições de deficiência de $\mathrm{K}^{+}$; este assun to é ainda motivo de muitas especulações.

Observa-se pela Figura 10 que o teor de proteína nas folhas das plantas do tratamento $K_{1}$ foi menor do que nas plantas do tratamento $\mathrm{K}_{2}$, consideradas normais. Nos tecidos de colmo/folha excetuando a época da última amostragem (60 dias esses teores tenderam a aumentar. Esses resultados podem ser atribuídos aos desarranjos metabólicos na deficiência de $\mathrm{K}^{+}$que dependem em última anālise do estädio de desenvolvimento da planta bem como de fatores externos. Depreende-se portanto dos resultados, que a nutrição potāssica desempenha sem dūvida algu ma, um papel chave nas transformações do nitrogênio em plantas de cana-de-açúcar. Entretanto, grande parte da literatura que examinam, os efeitos do potássio sobre o metabolismo do nitrogênio nem sempre trata dos efeitos das doses crescentes daquele elemento sobre a distribuição das vārias frações nitroge nadas nas diferentes partes das plantas.

\subsection{Interação Potássio/Atividade de Invertases}

A atividade de invertase ácida $(\mathrm{pH} 5,5)$ e invertase neutra ( $\mathrm{pH} 7,1)$ foi detectada em todos os segmentos de parte aérea de cana-de-açúcar (Tabela 10) durante todo o perío do considerado. Em todos os casos, entretanto, constatou-se que 


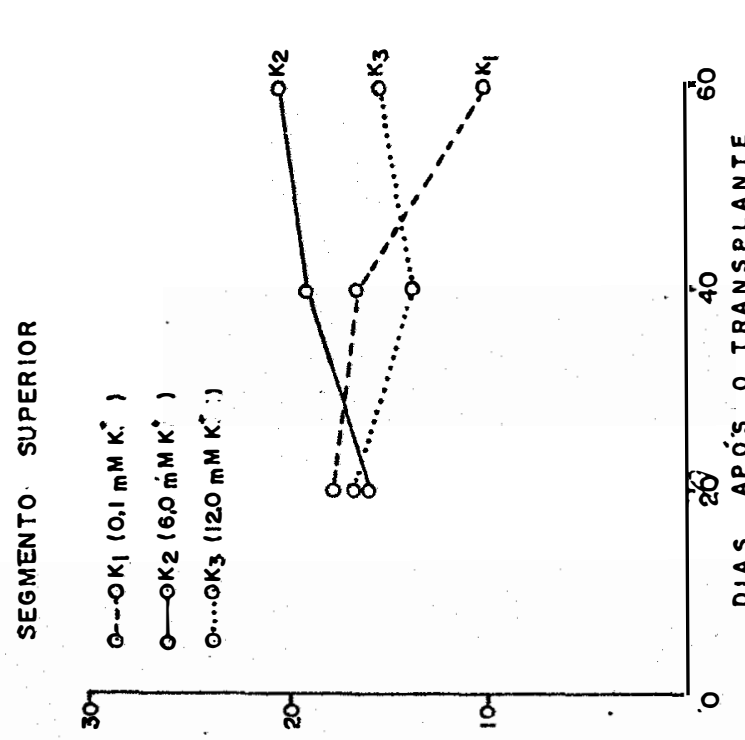

.63.

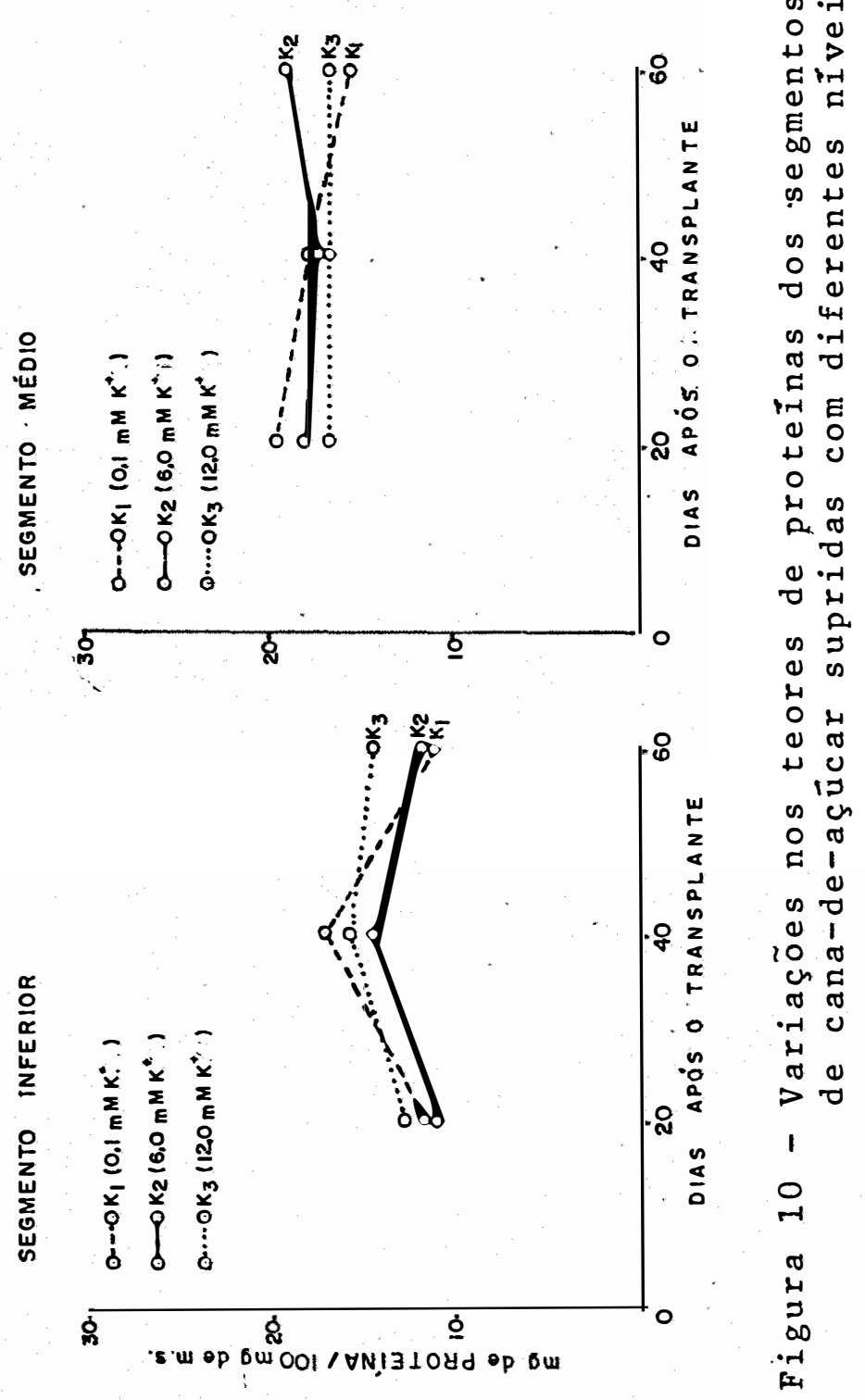


a atividade de invertase ácida foi sempre maior do que a ativi dade de invertase neutra principalmente nas folhas e também na região colmolfolha. Este resultadó está dẹ acordo com o de HATCH e GLASZIOU (1963) que observaram a existência de uma estreita correlação entre atividade de invertase ácida e taxa de crescimento de tecidos imaturos,bem como entre atividade de in vertase neutra e conteūido de açúcares em tecidos armazenados (colmo) de cana-de-açúcar adulta.

As pronunciadas diferenças nas atividades de in vertases dentro de cada segmento, podem estar associadas com a localização da enzima na célula. SAMPIETRO et alií(1980) além de demonstrarem esse fato, relatam que diferentes invertases ocorrem em diferertes tecidos de cana-de-açūcar. Além disso, diferentes estádios dentro de um mesmo tecido são acompanhados por diferentes invertases, e portanto diferentes tecidos pode riam conter diferentes invertases. Essa possibilidade foi con firmada por FLEISCHMACHER et ali $i$ (1980) comparando invertases de parede celular dos äpices de cana-de-açúcar e dos calos obtidos destes ápices.

Apesar das flutuações nos níveis de atividade com o tempo; os resultados levam à sugestão de que existe uma correlação positiva entre a taxa de crescimento e atividade da enzima. A invertase ácida correlaciona-se com o processo de inversão de sacarose e produção de hexoses para suprir as exi gências de energia e carbono que mantém as reações biossintéticas nos estádios iniciais do desenvolvimento. A invertase neutra, por sua vez, parece fazer parte do sistema que controla o fluxo de açūcares em tecidos armazenadores maduros (GAYLER e GLASZIOUU, 1972). Segundo HATCH e GLASZIOU (1963) e SLACK (1965), durante a fase jovem (de divisão e alongamento celular), as células dos internódios de cana-de-açūcar, contém grandes quanti dades de invertase ácida solúvel, que tendem a diminuir logo de 
pois que termina o alongamento celular. As células mais maduras contêm uma invertase ácida insolúvel, ligada a parede celu lar e uma invertase neutra (HATCH e GLASZIOU, 1963 e HAWKER e HATCH, 1965). A primeira parece exercer maior controle sobre o conteúdo de matéria seca acompanhando a extensão do cres cimento celular, enquanto que a invertase ácida solúvel ou componente vacuolar, parece estar relacionada com a regulação do turgor de pressão e reservatörio interno de açúcares (GAYLER e GLASZIOU, 1972).

Com relação aos tratamentos $K_{1}, K_{2}$ e $K_{3}$ verifica-se pelos dados da Tabela 10 que não se observou diferenças significativas entre os níveis de $\mathrm{K}^{+}$e a atividade de inverta ses. Apesar disso o tratamento $\mathrm{K}_{1}$ se diferenciou dos demais por mostrar uma tendência de aumentar os valores de atividade de invertase ácida,principalmente nos primeiros 20 dias. Esse resultado contraria aqueles obtidos por HARTT (1934) que obser vou que tanto no colmo como nas folhas das plantas a atividade dessa enzima foi menor do que nas plantas normais.

o aumento de atividade enzimática observado nas con dições do ensaio implica obviamente numa maior inversão de sacarose o que restaria pouca quantidade para ser acumulada. Por outro lado, a deficiência de potássio poderia prejudicar não somente o processo de sintese como também de translocação de sacarose elou a própria sintese da invertase.

As Figuras 11 e 12 mostram as variações pára os níveis de invertase àcida e invertase neutra dentro de cada segmento em função dos níveis de $\mathrm{K}^{+}$. Verifica-se pela análise dos dados que em todos os tratamentos tanto a invertase àcida como a invertase neutra apresentaram uma tendência para diminuir, após os 40 dias.

Com relação à invertase àcida, essa diminuição 


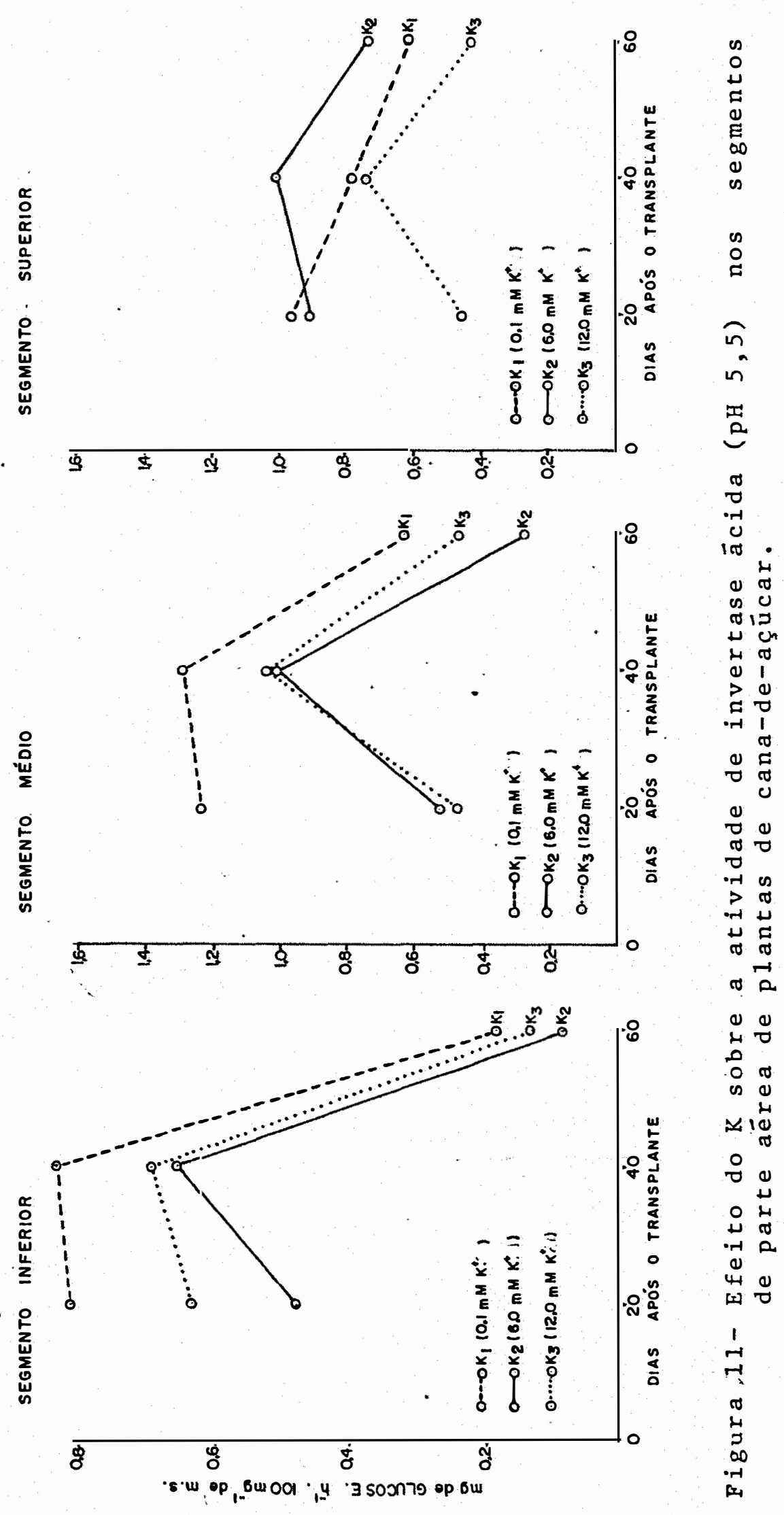



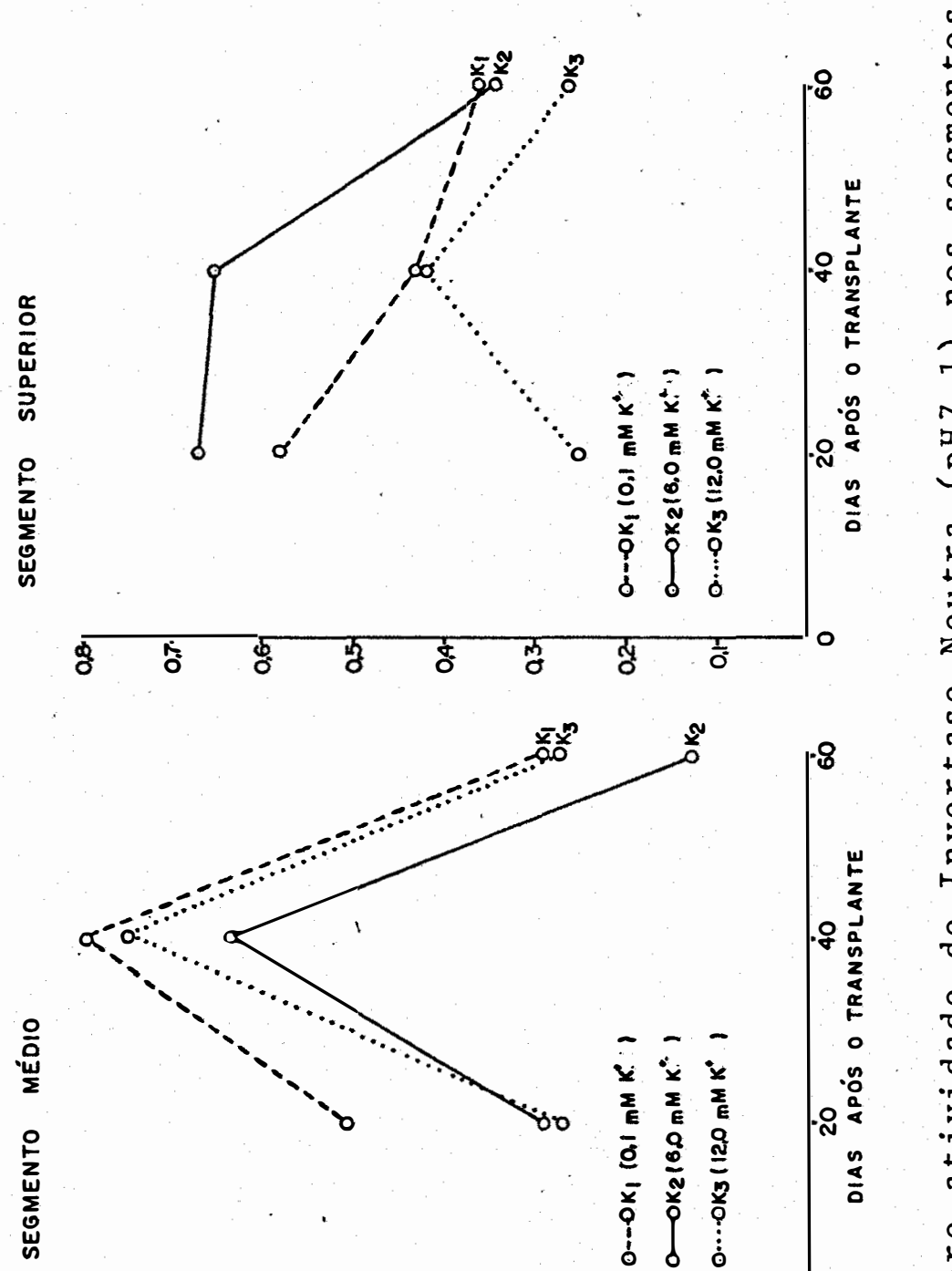
pode estar associada com a pouca idade da cana-de-açúcar utili zada no ensaio ou com o acúmulo de sacarose no colmo o que pro vocaria sua inativação conforme os relatos de SAMPIETRO et alii $(1980)$.

Os dados obtidos em relação à diminuição da invertase neutra não concordam com aqueles obtidos por GAYLER $e$ GLASZIOU (1972) (1963) que mostraram que a atividade dessa en zima começa a aparecer à medida que a invertase ācida tende a desaparecer. Resultados semelhantes foram encontrados por HATCH e GLASZIOU (1963) em experimentos com cana-de-açúcar.

Embora não se tenha dados suficientes para discutir a interrelação observada entre a atividade dessas enzimas e o efeito do $\mathrm{K}^{+}$, acredita-se que este íon não seja ativador especifico de invertase.o que contraria os resultados obtidos por HARTT (1934). Deve-se considerar entretanto que a autora utilizou outra metodologia: cada parte da planta isoladamente, cana-de-açūcar com 7 meses de idade além de outras concentrações de $\mathrm{K}^{+}$na solução nutritiva.

Recentemente SUZUKI (1982) estudando a interação entre potässio/atividade de invertase de cana-de-açúcar com 180 dias de idade, encontrou nas bainhas foliares, uma tendência oposta, como seja, para o aumento de invertase alcalina e estabilização em valores baixos para invertase ácida.

Apesar da grande quantidade de trabalhos publicados sobre atividade de invertases em cana-de-açūcar sobretudo pelas equipes de HATCH et alii (1963), SAMPIETRO et alii (1980) e mais ALEXANDER (1964, 1965, 1973), HUMBERT (1968a) e recentemente SUZUKI (1982) poucos dentre eles tem correlaciona do as atividades destas enzimas com suprimento de potássio. En tre os poucos sobre esse assunto, estā o MATSUSHITA e URITANI 
(1966) que demonstraram que $\mathrm{K}^{+}$e o $\mathrm{Na}^{+}$são ativadores especí ficos de invertases em plantas de batata doce. JONES(1966) por sua vez apresentou evidências de que a deficiência de $\mathrm{K}^{+}$tem um efeito depressor sobre as atividades de invertases, produção de ácido glicérico e sobre a sintese de Uridina-difosfogli cose (UD'PG) em plantas de tomate.

CROCOMO (Comunicafão pessóal) iniciou a partir dos trabalhos de SILVEIRA (1980) uma série de estudos com cana-de-açúcar em diferentes estádios de desenvolvimento, com o objetivo de compreender que fases metabolismo da planta estão relacionadas com as maiores exigências de $\mathrm{K}^{+}$e o envolvimento desse íon com a sintese e translocação de sacarose e enzimas relacionadas. Apesar das evidências apresentadas no presente ensaio de que hā uma estreita correlação entre $\mathrm{K}^{+}$, metabolis mo de açúcares e atividade de invertase, observa-se contudo que a natureza correlacional da evidencia,parece apresentar a desvantagem de não permitir estabelecer uma relação bem definida de causa-e-efeito. Desse modo, infere-se dos resultados obtidos, a necessidade de se realizar mais ensaios, com o uso de inibidores de invertases seletivos e especificos, que possam dar informações mais sólidas sobre a função destas enzimas. Os resultados obtidos no presente trabalho estão indicando que a quantidade e espécie de açūcar armazenado estão mais estreitamente correlacionados com o nível de invertase ácida do que com o de invertase neutra. 
Os resultados obtidos no presente trabalho, con siderando-se as condições descritas para o ensaio, permitem apresentar as conclusões e observações que se seguem:

os três níveis de potássio utilizados no experí mento $(0,1 ; 6,0$ e $12,0 \mathrm{mM})$ influenciam diferentemente o estádio inicial do desenvolvimento da planta de cana-de-açúcar sendo que, quanto maior a concentração de $\mathrm{K}^{+}$, maior $\overline{\mathrm{a}}$ a $\mathrm{taxa}$ de crescimento, o que foi comprovado pelos dados de matéria seca.

Com a redução da concentração de $\mathrm{K}^{+}$de 6,0 para $0,1 \mathrm{mM}$ na solução nutritiva, obtém-se os mais a1tos teores de sacarose, açūcares redutores (AR) e açūcares reduto res totais (ART). o conteūdo de açücares é geralmente maior nos tecidos da baínha/colmo diminuindo a medida que se aproxima dos tecidos da folha.' Hä uma correlação inversa entre o teor de sacarose e os níveis de açūcares redutores, indicando pelo teor de AR produzido, uma eficiente inversão de sacarose pela enzima invertase principalmente em condições de deficiência.de potässio.

Não foram observados efeitos significativos, di- 
retos do $\mathrm{K}^{+}$na atividade de invertase äcida e invertase neutra, apesar de que, em bairas concentrações desse elemento, a atividade dessas enzimas, foi de uma maneira geral, bem mais elevada. A idade fisiológica das plantas, parece exercer uma influência mais decisiva do que os niveis de $\mathrm{K}^{+}$sobre a atividade das énzimas. Embora de iñ̈cio, ambas tenham apresentado ni veis elevados, a invertase àcida mostrou depois de um certo tempo, tendência para aumentar, e depois diminuir. Em todos os casos, sua atividade foi sempre maior do que a atividade da invertase neutra.

o elevado, nível de atividade de invertase àcida na folha ao lado de baixos teores de sacarose evidencia a exis tência de uma estr sitá correlação entre a inversão da sacarose e a atividade desta enzima. No tecido da bainha/colmo, onde a atividace da enzima foi muito baixa, a sacarose se acumulou.

A presença do $\mathrm{K}^{+}$em nỉveis inadequados na solução nutritiva $(0, I \mathrm{mM})$ provocou aumento no conteúdo de $\mathrm{N}-\alpha-\mathrm{NH}_{2}$ e diminuição nos nj̉veis de proteỉnas e N-total. 
6. LITERATURA CITADA

ALEXANDER, A.G., 1964. Sucrose-enzyme relationships in

immature sugarcane as affected by varying levels of nitrate and potassium supplied in sand culture. Journal of Agriculture. of the University of Puerto Rico. Rio Piedras, 48(3):165-231.

ALEXANDER, A.G., 1965a. Physiological studies of enzymes catalyzing the śythesis and hydrolysis of sucrose, starch and phosphorylated hexose in sugar cane. Journal of Agriculture of the University of Puerto Rico. Rio Piedras, $49: 60-75$.

ALEXANDER, A.G., 1965b. Hydrolytic proteins of sugarcane: The acid invertases. Journal of Agriculture of the University of Puerto Rico. Rio Piedras, 49:287-307.

ALEXANDER, A.G., 1967. Purification and electrophoretic behavior of sugarcane invertases. Journal of Agriculture of the University of Puerto Rico. Rio Piedras, 51(1):39-45.

ALEXANDER, A.G., 1969. Comparative studies of yeast and sugarcane invertase. Journal of Agriculture of the University of Puerto Rico. Rio Pedras, 53:41-56. 
ALEXANDER, A.G., 1973. Sugarcane physiology. Amsterdam,

E1sevier. $752 \mathrm{p}$.

ALEXANDER, A.G. e G. SAMUELS, 1968. "Controlled-temperature studies of growth enzymology and sucrose production by two sugarcane varieties in Puerto Rico. Journal of Agriculture of the University of Puerto Rico. Rio Piedras, 52(3):204-217.

AMORIM, H.V. e E.A. ZAGO, 1978. Anälises para o controle da fermentação. Apostila do Departamento de Química-ESALQ/USP. Piracicaba. $26 \mathrm{p}$.

BARKER, A.V. e R. BRADFIELD, 1963. Effect of potassium and nitrogen on the free amino acid content of corn plant. Agronomy Journa1, Madison, Wisconsin, 55:465-470.

BASSO, L.C., 1974. Formação de di- e poliaminas em plantas deficientes em potássio e magnésio. Piracicaba, SP. ESALQ/USP. (Dissertação de Mestrado).

BATER, L.D., 1960. Plant and soil composition relationships as applied to cane fertilization. Hawaiian Planters'Record. Edith. L. Hase1wood, Associate Hono1u1u, 56:1-153.

BERINGER, H., 1982. O potássio na produção das culturas. In: Potássio na Agricultura Brasileira. Instituto da Potassa e Fosfato (U.S.A.). Instituto Internacional da Potassa (suiça). Londrina. p.163-175.

BIELISKI, R.L., 1960. The physiology of sugar cane III. Caracteristic of sugar uptake in slices of mature and imature storage tissue. Australian Journal Biological Sciences. Me1bourne, $13(\overline{3): 203-220 .}$ 
BLANCHET, R.; R. STUDER e C. CHAVMONT, 1962. Some aspects of interactions in the water supply of plants. Annales Agronomiques. Paris, 13:93-110.

BOWEN, J.E., 1972. Sugar transport in immature internoda1 tissue of sugarcane. I. Mechanism and kinetics of accumulation. Plant Physiology. Washington, 49:82-86.

BOWEN, J.E., 1973. Effect of micronutrient deficiencies upon macronutrient accumulation in sugar-cane. Tropical Agriculture. Trinidad, West Indien, 50:129-137.

BOWEN, J.E., 1975. Micronutrient composition of sugarcane sheaths as affected by age. Tropical Agriculture. Trinidad, West Indien, 52:131-137.

BOWEN, J.E., 1981. Micro-element nutrition of sugarcane. I- Effect of micro-elements on growth and yield. Tropical. Agriculture. Trinidad, West Indien, 48(1):13-21.

BURR, G.O., C.E. HARTT, H.W. BRODIE, T. TANIMOTO, H.P. KORTSCHAK, D. TAKAHASHI, F.M. ASHTON e R.E. COLEMAN, 195?. Sugarcane Plant. Annual Review of Plant Physiology. Standford, California, 8:275-308.

CROCOMO, O.J., 19?9. Assimilação do nitrogênio pela plantas. In: Fisiologia Vegetal I. FERRI, M.G. E.P.U. - EDUSP. São Paulo. p.179-207.

CROCOMO, O.J. e L.C. BASSO, 1974. Accumulation of putrescine and related aminoacids in potassium deficient Sesamum. Phytochemistry. New York, 13:2659-2665. 
CROCOMO, O.J., J.A.G. SILVEIRA e N. OCHOA-ALECO, 1981. Formas nitrogenadas e metabolismo de açúcares e crescimento em cana-de-açücar (Saccharum spp.) cv. NA56-79. In: Congresso Nacional da Sociedade de Técnicos Açucareiros do Brasil. 2 ? Simpósio tatinoamericano sobre modalidades de financiamento à produção de energia renovável. Anais. Rio de Janeiro $(\mathrm{STAB}), 2: 282-304$.

CROCOMO, O.J., W.R. SHARP e M.T.V. CARVALHO, 1979. Controle da morfogênese e desenvolvimento de plantas em cultura de tecidos de cana-de-açúcar. Resultados experimentais. Anais. 19 Congresso Nacional da Sociedade dos Técnicos Açucareiros do Brasil (STAB). Maceió, 1:241-243.

DAVIES, D.R., 1974. Some aspects of sucrose metabolism. In: Plant Carbohydrate Biochemistry (PRIDAN, J.B., ed.). Academic Press London e New York, 10(5):61-81.

DILLEWIJN, C. van, 1952. Botany of sugarcane. Wa1than, Mass . U.S.A. The Chronica Botanica. $371 \mathrm{p}$.

EPSTEIN, E., 1972. Mineral nutrition of plants. New York, John Wiley. $341 \mathrm{p}$.

ETCHEBERRIGARRY, J.L., M.A. VATTUONE e A.R. SAMPIETRO, 1981. B-galactosidase from sugar-cane. Phytochemistry, New York, $20: 49-51$.

EVANS, H.J. e G. SORGER, 1966. Role of mineral elements with emphasis on the univalent cations. Annual Review of Plant Physiology. Standford, California, 17:47-76. 
EVANS, J.H. eR.A. WILDES, 1971. Potassium and its role in enzyme activation. In: $8^{\text {th }}$ Colloquium Internationa 1

Potash Institute, Uppsolo/Sweden. Ed. International Potash Institute Berne Swetzarland. 244 pages.

FLEISCHMACHER, O.L., F.E. PRADO, A.R. SAMPIETRO, 1980. Ce11 wall invertases from apex and callus tissues of sugarcane.

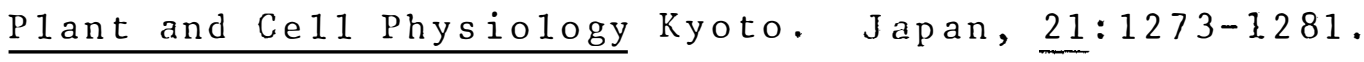

ERYDMAN, R.B. eW.Z. HASSID, 1963. Biosynthesis of sucrose with sugarcane leaf preparations. Nature. London, 199: $382-383$.

GAYLER, K.R. e K.T. GLASZIOU, 1972. Physiological functions of acid and newtral invertases in growth and sugar storage in sugar-cane. Physiologia Plantarum. Kobenhavn, Lund, $27: 25-31$.

GLASZIOU, K.T., 1961. Accumulation and transformation of sugars in stalks of sugar-cane. Origin of glucose and frutose in the inner space. Plant Physiology. Washington, 36: $175-179$.

GLASZIOU, K.T., 1962. Accumulation and transformation of sugars in sugar cane stalks: Mechanism of inversion of sucrose in the inner space. Nature: London, 193:1100.

GLASZIOU, K.T. e K.R. GAYLER, 1972. The role of cel1 walls in sucrose transport in sugarcane. Plant Physiology. Washington, 49: $912-913$. 
GLOVER, J., 1973. The dark respiration of sugar-cane and the 1 ass of photosynthate during the growth of a crop. Annals of Botany. Oxford, 37:845-952.

GOODWIN, T.W. e E.I. MERCER, 1972. Introduction to plant biochemistry. Pergamon Press, Oxford, New York. 359 p.

HAAG, H.P., 1965. Estudos de nutrição mineral da cana-de-açü* car variedade CB41-76, cultivada em solução nutritiva. ESALQ/USP. Livre Docência. Piracicaba, São Paulo. 141 p.

HAEDER, H.E. e K. MENGEL, 1974. Effect of nutrition on CO 2 assimilation and grain filing of wheat during the reproductive stage. In: International Colloquium on Plant Analysis and Fertilizers Problems. Proceedings of the $7^{\text {th }}$ Co11oquium. Hannover. p.135-145.

HARTT, C.E., 1934. Some effects of potassium upon the amounts of protein and amino forms of nitrogen, sugars and enzyme activity of sugar-cane. Plant Physiology. Washington, $\underline{9}: 453-490$.

HARTT, C.E., 1969. Effect of potassium deficiency upon translocation of ${ }^{14} \mathrm{C}$ in attached blades and entire plants of sucarcane. Plant Physiology. Washington, 44:1451-1469.

HART' C.E., 1970.' Effect of potassium deficiency upon translocation of ${ }^{14} \mathrm{C}$ in detached blades of sugarcane. P1ant Physiology. Washington, 45:183-187. 
HARTT, E.C. e G.O. BURR, 1967. Factors affecting photosynthesis in sugarcane. In: Congress International Society Sugarcane Technology, $1={ }^{\text {th }}$ (Puerto Rico, 1965). Proceedings Amsterdan E1sevier. 590-608pp.

HARTT, C.E., H.P. KORTSCHACK, A.J. FORBES e G.O. BURR, 1963. Translocation of ${ }^{14} \mathrm{C}$ in sugarcane. Plant Physiology. Washington, 33:305-318.

HATCH, M.D., 1964. Sugar accumulation by sugarcane storage tissue: the role of sucrose phosphate. Biochemical Journal. Cambridge, $93: 521-526$.

HATCH, M.D. e K.T. GLASZIOU, 1963. Sugar accumulation cycle in Sugarcane. II. Relationship of Invertase Activity to Sugar Content and Growth Rate in Storage Tissue of Plants Grown in Controlled Environments. Plant Physiology. Washington, $38: 344-348$. HATCH, M.D., J.A. SACHER E K.T. GLASZIOU, 1963. Sugar accumulation cycle in sugarcane. I- Studies on enzymes of the cycle.. Plant Physiology. Washington, 38:338-343.

HATCH, M.D. e C.R. SLACK, 1970. Photosynthetic CO $2^{- \text {fixation }}$ pathways. Annuals Review of Plant Physiology. Standford Ca1ifornia, 21:141-162.

HAWKER, J.S. e M.D. HATCH, 1965. Mechanism of sugar storage by mature stem tissue of sugarcane. Physiologia plantarum. Kobenhavn, Lund, 18:444-453. 
HELIEBUST, J.A. e D.F. FORWARD, 1962. The invertase of the corn radicle and its activity in sucessive stages of growth. Canadiam Journa1 of Botany. Ottawa-Canadá, 40:113-126.

HOAGIJAND, D.R. e D.I. ARNON, 1950. The water culture method for growing plants without soil. California Agriculture. Berkeley Circular 347 .

HSIAO, T.C., R.H. HAGEMAN e E.H. TYNER, 1970. Effects of potassium nutrition on protein and total free amino acids in Zea mays. Crop Science. Madison, Wisconsin, 10:78-82.

HUMBERT, R.H., 1963. The growing of sugar-cane. Elsevier Publishing Company Amsterdan. 779 p .

HUMBERT, R.H., 1968. Potassium builds sugarcane quality. Better crops with plant food. Washington, $1: 28-29$.

HUMPHREYS, T. e E. ECHEVERRIA, 1980. Invertase and maltase in the free space of the maize scutellum. Phytochemistry. New York, 19:189-193.

JONES, L.H., 1966. Carbon-14 studies of intermediary metabolism in potassium-deficient tomato plants. Canadian Journal of Botany. Ottawa, Canadá, 44:297-307.

JONES, R.A. e P.B. KAUIFMAN, 1975. Multiples forms of invertase in developing oat internodes. Plant Physiology. Washington, 55:114-119. 
.80 .

JØRGENSEN, S.S., 1977. Guia Analítico. Metodologia utilizada para anälises químicas de rotina. Centro de Energia Nuclear na Agricultura - CENA. Piracicaba, São Paulo. 23p.

KABAT, A.E. e M.M. MAYER, 1967. Ninhydrin method for primary aminoacids. In: Experimental Imunochemistry, $2^{a}$. Edition. Springfield, Charles C. Thomas, U.S.A. p.561-563.

KARMANENKO, N.M., 1968. Effect of the main nutritional elements on the content and free amino acids, and the amino acids composition of protein, in the cell organoids of barley leaves. Soviet Plant Physiology,. New York, 1. $5: 662-666$.

KOCH, K. e K. MENGEL, 1972. Effect of a varied potassium nutrition on the uptake and incorporation of 1 abelled nitrate by young Tobacco plants (Nicotiana tabacum L.). Journal of the Science of Food and Agriculture. London, England, 23:1107-1112.

KOSHLAND, D.E.Jr. e S.S. STEIN, 1954. Correlation of bond breaking with enzyme specificity cleavage point of invertase. The Journa1 of Biological Chemistry. Baltimore, 208: $139-148$.

LAWTON, K. eR.L. COOK, 1954. Potassium in Plant nutrition. In: Advances in Agronomy Journal (A.G. NORMAN, ed.). New York, 6: $253-303$.

LOWRY, O.H., N.J. ROSEBROUGH, A. LEWIS FARR e R.J. RANDALL, 1951. Protein measurement with the folin phenol reagent. Journal Biological Chemistry. Ba1timore, 193:265-275. 
LUGO-LOPEZ, M.A., 1954. The affect of soil conditions on the sucrose content of sugar-cane. Journal of Agriculture of the University of Puerto Rico. Rio Piedras, 38(3):132-146.

LUGO-LOPEZ, M.A. e B.G. CAPO, 1954. The effect of weather and climate on the sucrose content of sugarcane. Journal of Agriculture of the University of Puerto Rico. Rio Piedras, $\underline{38}(4): 149-169$.

MACLACHLAN, G.A., A.H. DATKO, J. ROLLIT e E. STOKES, 1970.

Sugar levels in the pea epicotyl: regulation by invertase and sucrose synthetase. Phytochemistry, New York, $\underline{9}: 1023-1030$.

MADAN, V.K., K. SINGH, S. SHIVAPURI, H.P. PANDE e Y.R. SAXENA, 1980. Activity of invertase (s) in sugarcane leaves. International Sugar Journal. Lucknow, India, 82. p.55.

MAGALH ÄES, A.C.N., 1979. Anālise quantitativa dó crescimento. In: Fisiologia Vegeta1. I. FERRI, M.G., E.P.U. - EDUSP. São Pau1o. P. 331-350.

MALAVOLTA, E., 1980. Elementos de nutrição mineral de plantas. Editora Agronômica Ceres Ltda. São Paulo. $251 \mathrm{p}$.

MALAVOLTA, E., 1982. Nutrição mineral e arıbação da cana-de- açūcar. Departamento de Serviços Técnicos Agronômicos. U1trafértil, São Paulo. 80 p.

MALAVOLTA, E. e O.J. CROCOMO, 1982. O potássio e a planta. In: Symposium on Potassium in Brasilian Agriculture. Londrina, Paranà, $1: 3-70$. 
MARETZKI, A. eA.G. ALEXANDER, 1967. Gel filtration studies of invertase from sugarcane meristem. Enzimologia. Gravenhage, 33:299-307.

MATSUSHITA, K. e I. URITANI, 1974. Change in invertase activity of sweet potato in response to wounding and purification and properties of its invertases. Plant, Physiology, Washington, 54:60-66.

MENGEL, K., 1982. Factores y procesos que influyen en las necesidades de potasio de los cultivos. Revista de la Potasa, Sección, 9. Cultivo de Cereales Berna (Suiza). $(16-90)$.

MENGEL, K. e E.A. KIRKBY, 1978. Principles of Plant Nutrition International Potash Institute Berne, Switzerland. $593 \mathrm{p}$.

MURATA, T. e T. AKAZAWA, 1968. Enzimic mechanism of starch synthesis in sweet potato-roots. I- Requirement of potassium ions for starch synthetase. Archives of Biochemistry and Biophysic. New York, 126:873-879.

NELSON, N., 1944. A photometric adaptation of the Somogyi method for determination of glucose. Journal of Biological Chemistry. Baltimore, New York, 153:375-380.

NOWAKOWSKI, T.2. e M. BYERS, 1972. Effects of nitrogen and potassium fertilizers on contents of carbohydrates and free amino acids in italian ryègrass II - Changes in the composition of the non protein nitrogen fraction and the distribution of individual amino acids. Journal of the

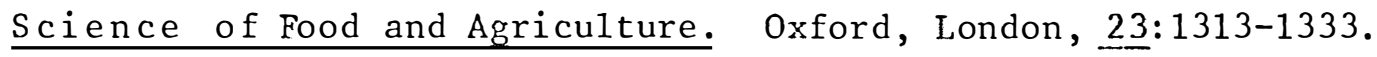


OCHOA-ALEJO, N., 1980. Efeito do nitrogênio nítrico, amoniacal e de uréia sobre o crescimento, carboidratos e compostos nitrogenados em cana-dé-açücar. (Saccharum spp. cv. NA56-79) cultivada em solução nutritiva. Mestrado-ESALQ. Piracicaba. 100 p.

OCHOA ALEJO, N. e O.J. CROCOMO, 1981. Biochemical and physiological aspects of sugarcane (Saccharum spp.). II. Effect of $\mathrm{NO}_{3}^{-}-\mathrm{N}, \mathrm{NH}_{4}^{+}$and urea-N on carbohydrate leve 1 and growth of cv. NA56-79. Energia Nuclear e Agricultura, Piracicaba, 3(2): 137-151.

ORLANDO F!, J., 19:2. Nutrição e adubação potássica da cana-de-açúcar no Brasil. In: Symposium on Potassium in Brasilian Agriculture. Londrina, Paranä, 2:3-29.

ORLANDO FO, J., H.P. HAAG, E. ZAMBELLO JR., 1980 . Crescimento e absorção de macronutrientes pela cana-de-açūcar, variedade CB41-76 em função da idade em solos do Estado de São Paulo. Boletim Técnico do PlanAlsucAR. Piracicaba, $2(1): 1-127$.

OZBUN, J.L., R.J. VOLK eW.A. JACKSON, 1965. Effect of potassium on photosynthesis, respiration and the utilization of photosynthetic reductant by immature bean leaves. Crop Science, Madison, Wisconsin, $\underline{5}: 69-75$.

PIRSON, A., 1955. Functional aspects in mineral nutrition of green plants. Annual Review of Plant Physiology. Standford, California, 6:71-114. 
PRADO, F.E., M.A. VATTUONF e A.R. SAMPIETRO, 1978. Sugarcane glycosidases. A new bound invertase from leaf sheaths.

In: International Society of Sugarcane Technologists Proceedings of the XVII Congress São Paulo, SP., Brasil. $16: 1683-1691$.

PRADO, F.E., A.R. SAMPIETRO e M.A. VATTUONE, 1979. Ammonium heptamolybdate an inhibitor of plant invertases.

Phytochemistry, New York, 18:1799-1802.

QUIROGA, E.N., T.R. DE MAXUD, M.A. VATTUONE, F.E. PRADO e A.R.'SAMPIETRO, 1977. Sugarcane glycosidases. A general view of the glycosidases from stalk. Plant Science Letters, Amsterdam, Netherlands, 8: $135-140$.

RICARDO, C.P.P. e D. SOVIA, 1974. Development of tuberous roots and sugar accumulation as related to invertases activity and mineral nutrition. Planta. Ber1in, 118:43-55.

RICHARDS, F.J.eR.G. COLEMAN, 1952. Occurrence of putrescine in potassium deficient barley. Nature, London, 170:460.

ROBINSON, E. e R. BROWN, 1952. The development of the enzyme - complement in growing root cells. Journal of Experimental Botany, Oxford, $\underline{3}(9): 356-374$.

SACHER, J.A., M.D. HATCH e K.T. GLASZIOU, 1963. Sugar accumulation cycle in sugarcane III. Physical and metabolic aspects af cycle in immature storage tissue. Plant Physiology, Washington, 38:348-354. 
SAMPIETRO, A.R., M.A. VATTUONE E F.E. PRADO, 1980. A regulatory invertase from sugarcane leaf-sheaths. Phytochemistry, New York, 19:1637-1642.

SAMUELS, G. e P. LANDRAU JR., 1952. The response of sugarcane to fertilizers. Journal of Agriculture of the University of Puerto Rico. Rio Piedras, 26:203-229.

SAMUELS, G., M. LUGO-LOPEZ e P. LANDRAU JR., 1952. Factors affecting the sucrose content os sugarcane fertilizers. Journal of Agriculture, of the University of Puerto Rico. Rio Piedras, $\underline{36}: 194-202$.

SAMUELS, G.; P. LANDRAU JR. e B.G. CAPO, 1956. The influence of fertility on the varietal response of sugarcane. Journal of Agriculture of the University of Puerto Rico. Rio Piedras, $\underline{40}(3): 120-123$.

SARRUGE, J.R., 1975. Soluções Nutritivas. Suma Phytopatologica. Piracicaba, $1: 231-233$.

SCOTT-RUSSEL, R. e D.T. CLARKSON, 1971. The uptake and distribuition of potassium in crop plant. In: Potassium Biochemistry and Physiology. International Potash Institute Berne. $79-92 \mathrm{pp}$.

SEITZ, K. eA. LANG, 1968. Invertase activity and cel1 growth in lentil epicotyls. Plant Physiology, Washington, 43: $1075-1082$.

SHANNON, L.M., 1968. Plant isoenzymes. Annual Review of Plant. Physiology. Standford, California, 19:187-210. 
SHEA, P.F., W.H. GOBELNAN e G.G. GERLOFF, 196?. The inheritance of efficiency in potassium utilization in snap beans (Phaseolus vulgaris, L.). Proceeding of the American Society for Horticultural Science. Genova, 91:268-293.

SILVEIRA, J.A.G., 1980. Aspectos bioquímicos e fisiológicos da relação K/N em cana-de-açücar cv. NA56-79 cultivada em solução nutritiva. Piracicaba, ESALQ/USP. 95p. (Tese de Mestrado).

SILVEIRA, J.A.G. e O.J. CROCOMO, 1981. Biochemical of sugarcane (Saccharum spp.). I. Effects of $\mathrm{NO}_{3}^{-}$-Nitrogen concentration on the metabolism of sugars an nitrogen. Energia Nuclear e.. Agricultura. Piracicaba, $\underline{3}(1): 19-23$.

SLACK, C.R., 1965. The physiology of sugarcane VIII. Diurnal fluctuations in the activity of soluble invertase in elongating internodes. Australian Journal of Biological Sciences. Me1bourne, Victoria, 18: 781-788.

SMITH, T.A. e.C. SINCLAIR, 1967. The effects of acid feeding on amine formation in barley. Annals of Botany, Oxford, London, 31:103-111.

SOMOGYI, N.A., 1945. A new reagent for the determination of stigars. Journal of Biological Chemistry. Baltimore, New York, 160:61-68.

SUM, W.F., P.J. ROGERS, I.D. JENKINS e R.D. GUTHRIE, 1980. Isolation of invertase from banana fruit (Musa cavendishii). Phytochemistry, New York, 19:399-401. 
SUZUKI, J., 1982. Biossíntese e acúmulo de sacarose em cana-de-açūcar (Saccharum spp.): Influência do íon potássio durante diferentes estádios de crescimento. Tese de Doutoramento - ESALQ/USP. Piracicaba. $96 \mathrm{pp}$.

VATTUONE, M.A., F.E. PRADO e A.R. SAMPIETRO, 1981. Ce11 wa11 invertase from sugarcane. Phytochemistry, New York, 20: $189-191$.

VON UEXUELL, H.R., 1968. Potassium nutrition of tropical crops. In: KILMER, V.J., S.E. YOUNTS e N.C. BRADY (eds.). The role of potassium in agriculture american society of agronomy. Crop. Science. Madison, Winconsin, 385-421p.

WARD, G.M., 1953. Physiological and biochemical studies in plant metabolism VII. The invertase of the seedling wheat 1eaf. Canadian Journa1 of Botany. Ottawa, Canada, 31:81-89.

ZAGATTO, E.A.G., A.O. JACINTHO, B.F. REYS, F.J.KRUG, H. BERGAMIN FO, L.C.R. PESSENDA, J. MORTATTI e M.F. GINE, 1981. Manual de Anālises de Plantas e Āguas empregando Sistemas de Injeção em Fluxo. Centro de Energia Nuclear na Agricultura/USP. Piracicaba, $45 \mathrm{pp}$.

2AGO, E.A., 1978. Acúmulo de putrescina e interrupção da sintese proteica em feijoeiro (Phaseolus vulgaris L.) deficiente em potässio. Piracicaba, SP., ESALQ/USP. (Dissertação de Mestrado). $48 \mathrm{pp}$. 
.88 .

7. TABELAS 
Tabela 2 - Matéria seca produzida em três estádios do crescimento por segmentos da parte aérea de plantas de ça na-de-açúcar, cultivadas em solução nutritiva contendo 3 concentrações de potássio.

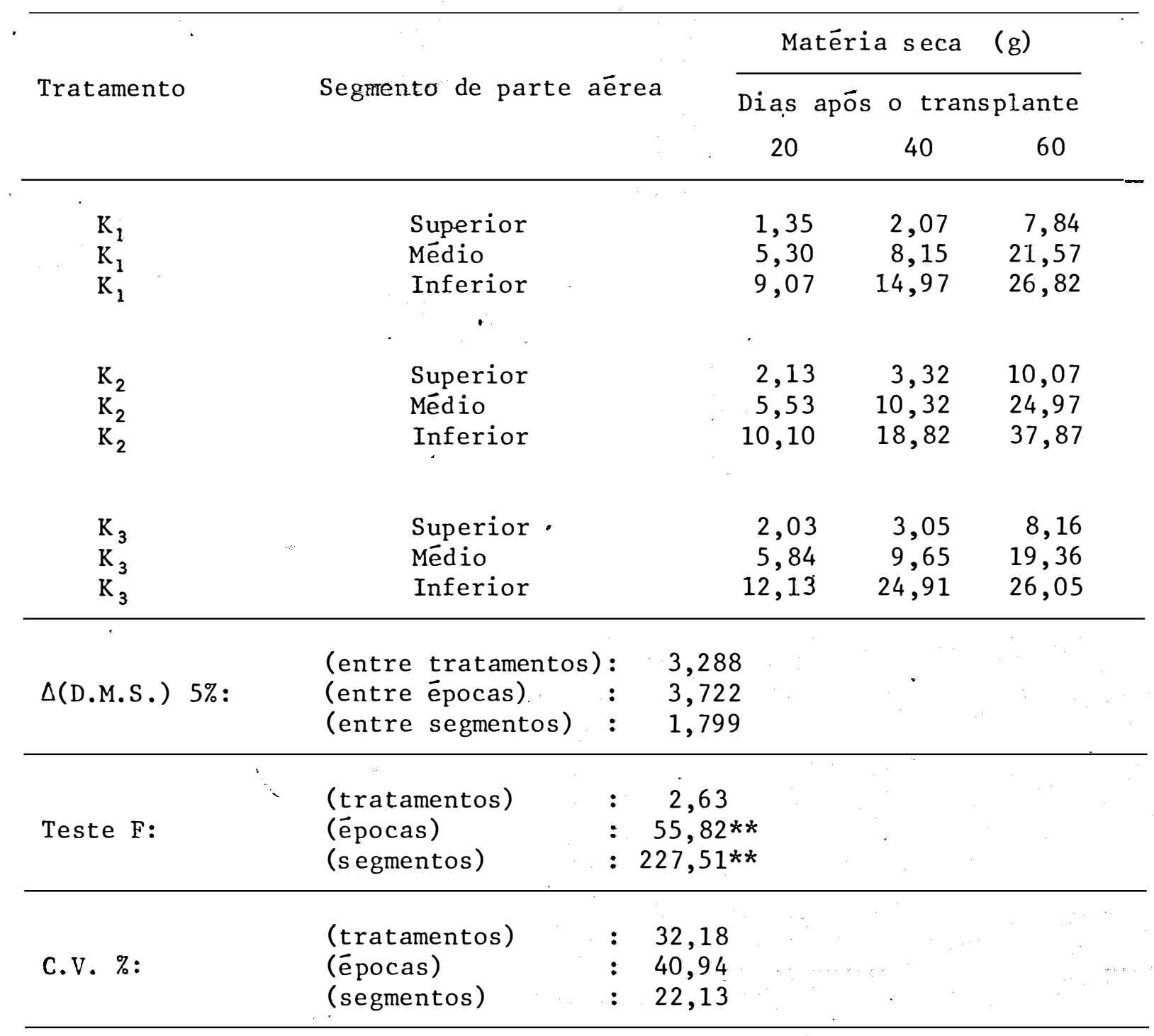

**Significativo ao nível de $1 \%$.

$\Delta:$ Diferença mínima significativa (Teste de Tukey 5\%) C.V.: Coeficiente de variação. 
Tabela 3 - Teores de potássio nos segmentos de parte aérea de plantas de cana-de-açúcar cultivadas em solução nutritiva contendo três concentrações de potássio.

\begin{tabular}{|c|c|c|c|c|}
\hline \multirow[b]{2}{*}{ Tratamento } & \multirow{2}{*}{ Segmento de parte aérea } & \multicolumn{3}{|c|}{ Potāssio (\%) } \\
\hline & & $\begin{array}{c}\text { Dias após } \\
20\end{array}$ & $\begin{array}{c}0 \operatorname{tra} \\
40\end{array}$ & $\begin{array}{c}\text { lante } \\
60\end{array}$ \\
\hline $\begin{array}{l}K_{1} \\
K_{1} \\
K_{1}\end{array}$ & $\begin{array}{l}\text { Superior } \\
\text { Médio } \\
\text { Inferior }\end{array}$ & $\begin{array}{l}0,99 \\
1,63 \\
1,18\end{array}$ & $\begin{array}{l}0,83 \\
1,04 \\
0,99\end{array}$ & $\begin{array}{l}1,12 \\
0,98 \\
0,49\end{array}$ \\
\hline $\begin{array}{l}\mathrm{K}_{2} \\
\mathrm{~K}_{2} \\
\mathrm{~K}_{2}\end{array}$ & $\begin{array}{l}\text { Superior } \\
\text { Médio } \\
\text { Inferior }\end{array}$ & $\begin{array}{l}2,29 \\
3,06 \\
4,85\end{array}$ & $\begin{array}{l}2,00 \\
3,05 \\
5,04\end{array}$ & $\begin{array}{l}1,80 \\
3,41 \\
3,97\end{array}$ \\
\hline $\begin{array}{l}K_{3} \\
K_{3} \\
K_{3}\end{array}$ & $\begin{array}{l}\text { Superior } \\
\text { Médio } \\
\text { Inferior }\end{array}$ & $\begin{array}{l}2,62 \\
3,14 \\
5,54\end{array}$ & $\begin{array}{l}2,34 \\
2,88 \\
5,05\end{array}$ & $\begin{array}{l}2,24 \\
3,89 \\
4,49\end{array}$ \\
\hline$\Delta($ D.M.S. $):$ & $\begin{array}{lll}\text { (tratamentos) } & 0,201 \\
\text { (épocas) } & : & 0,254 \\
\text { (segmentos) } & : & 0,201\end{array}$ & & . & \\
\hline Teste $\mathrm{F}:$ & 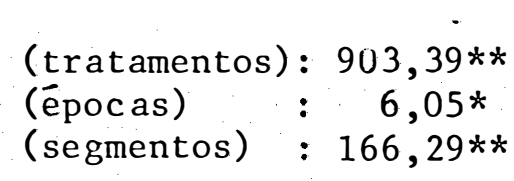 & & & \\
\hline C.V. \%: & $\begin{array}{lll}(\text { tratamentos }): & 9,16 \% \\
(\text { épocas }) & : & 13,32 \% \\
(\text { segmentos }) & : & 12,12\end{array}$ & & & . \\
\hline
\end{tabular}

*Significativo a $5 \%$. **Significativo a $1 \%$.

Significado dos símbolos - Ver Tabela 2. 
Tabela 4 - Conteúdo de Açūcares Redutores Totais (ART), Açūcares Redutores (AR) e Sacarose estimada nos segmentos de parte aérea de plantas de cana-de-açúcar, aos 20 dias após o transplante para solução nutritiva contendo 3 concentrações de potássio.

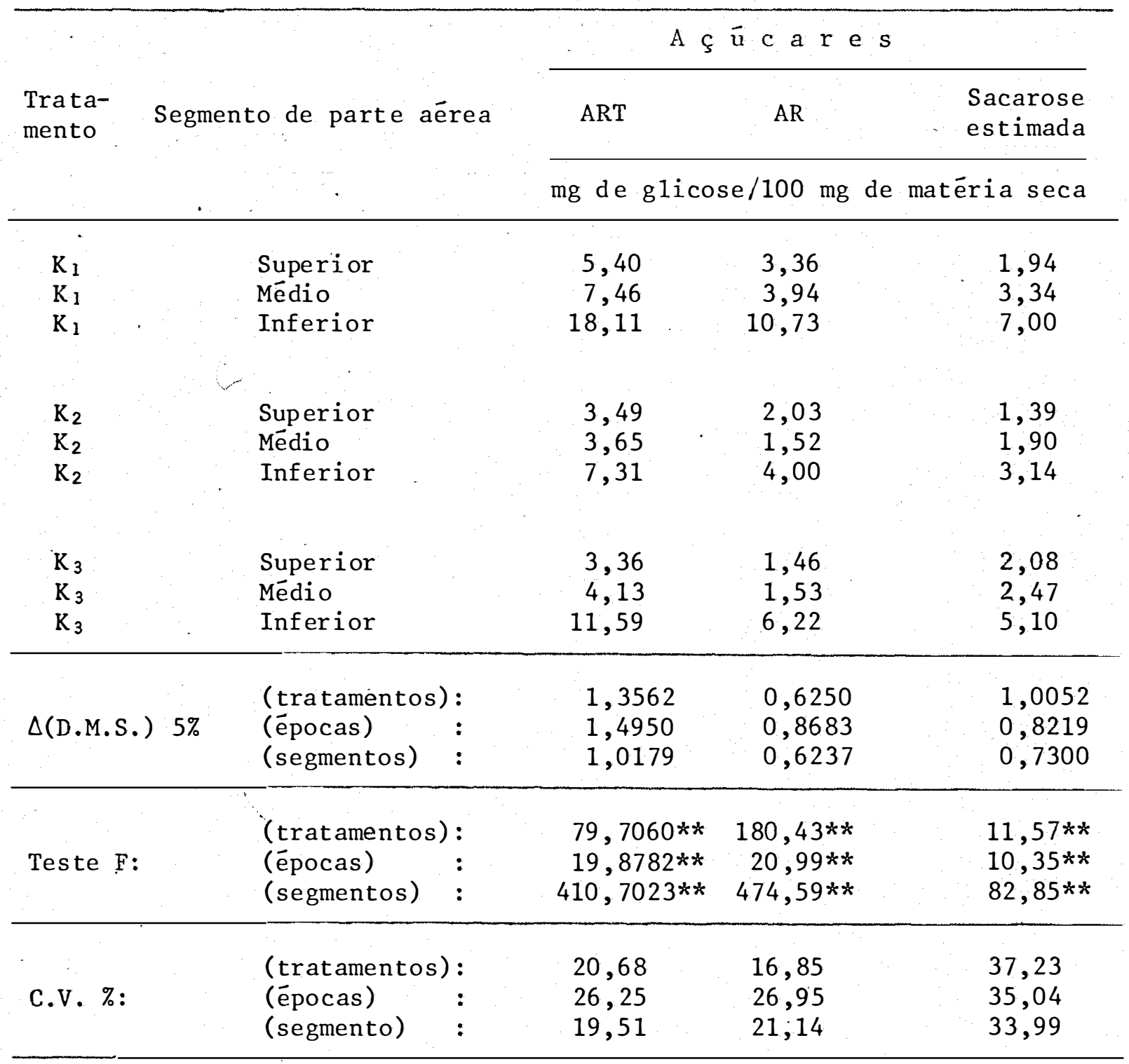

Sacarose estimada(\%): ART - AR - 0,95.

Significado dos simbolos - Ver Tabela 2. 
Tabela 5 - Conteúdo de Açūcares Redutores Totais (ART), Açūcares Redutores (AR) e Sacarose estimada nos segmentos de parte aérea de plantas de cana-de-açúcar aos 40 dias após o transplante para solução nutritiva contendo 3 concentrações de potássio.

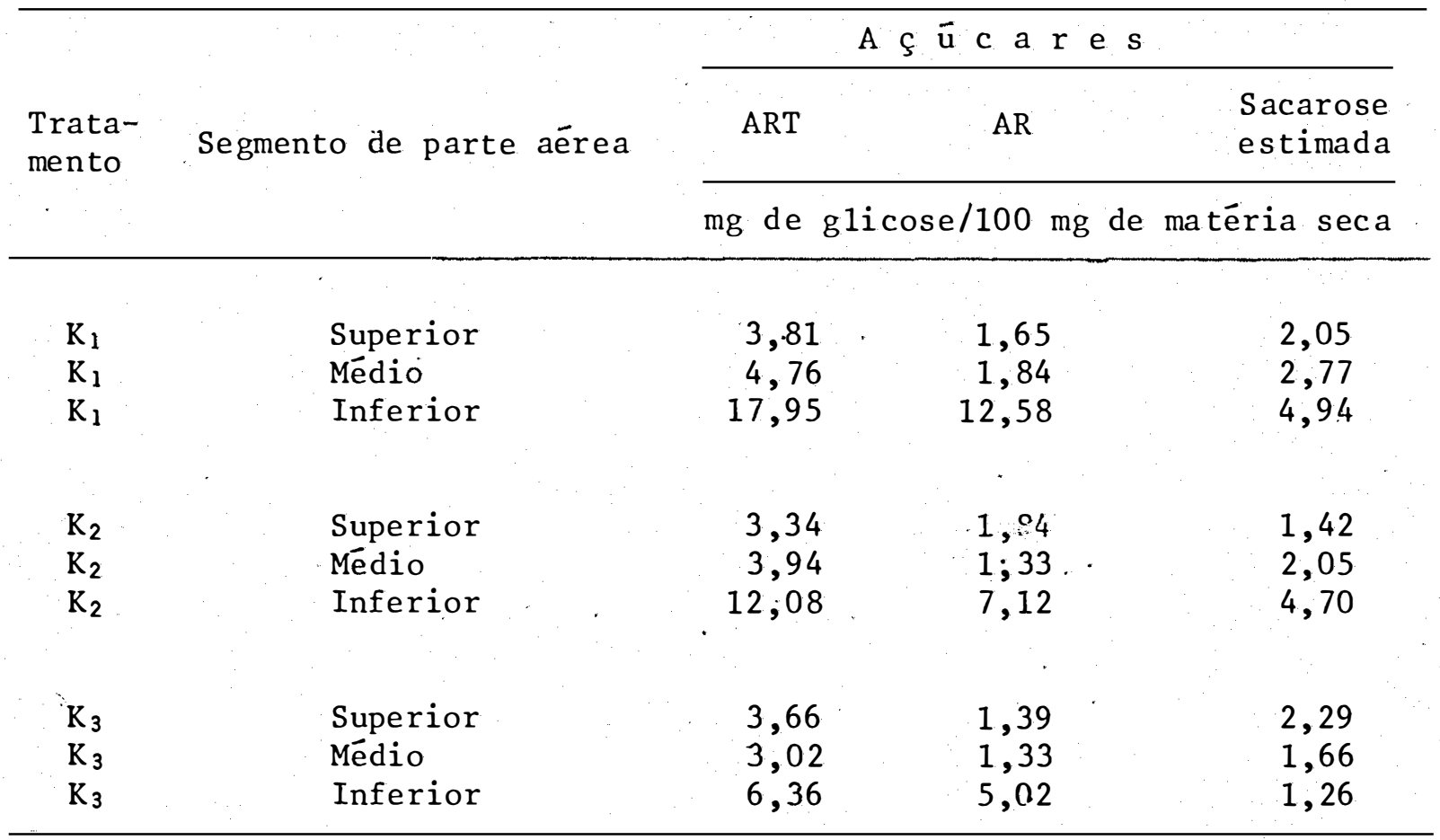

Valores de D.M.S., Teste F e C.V. dos teores de àçūcares são apresentados na Tabela 4 . 
Tabela 6 - Conteūdo de Açūcares Redutores Totais (ART), Açúcares Redutores (AR) e Sacarose estimada nos segmentos de parte aérea de plantas de cana-de-açúcar aos 60 dias após o transplante para solução nutritiva contendo 3 concentrações de potássio.

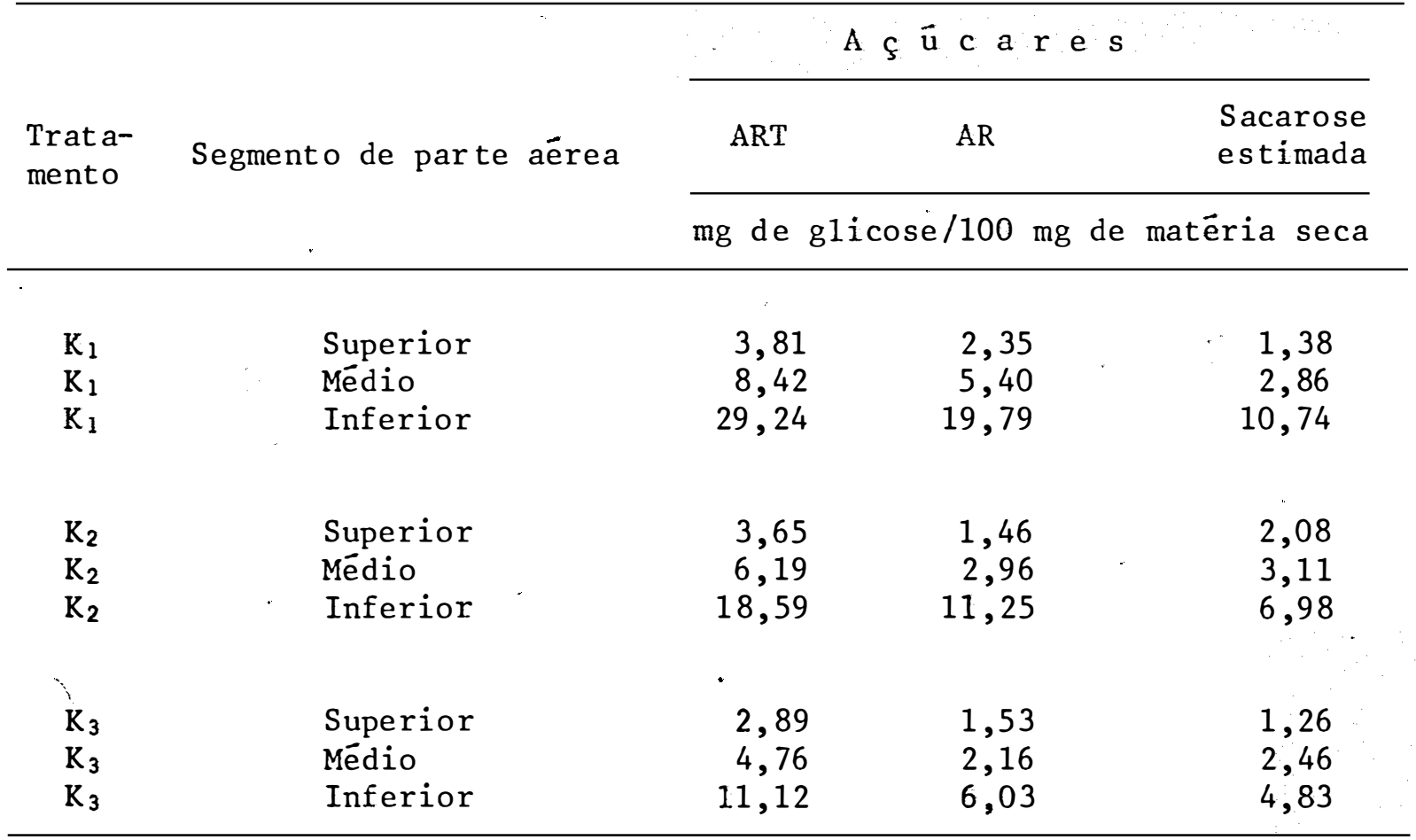

Valores de D.M.S., Teste F e C.V. dos teores de, açūcares, são apresentados na Tabela 4. 
Tabela 7 - Teores de $\mathrm{N}$-tota $1, \mathrm{~N}-\alpha \mathrm{NH}_{2}$ e proteinas nos segmentos de parte aérea de plantas de cana-de-açücar, aos 20 dias após o transplante para solução nutritiva con tendo 3 concentraçóes de potássio.

\begin{tabular}{|c|c|c|c|c|c|}
\hline \multirow{2}{*}{$\begin{array}{l}\text { Trata- } \\
\text { mento }\end{array}$} & \multirow[b]{2}{*}{$\because$} & \multirow{2}{*}{$\begin{array}{l}\text { Segmento de } \\
\text { parte aérea }\end{array}$} & \multirow{2}{*}{$\frac{N-\text { total }}{(\%)}$} & $\mathrm{N}-\mathrm{ONH}_{2}$ & \multirow{2}{*}{$\frac{\text { Proteína }}{(\mathrm{mg} / 100 \mathrm{mg} \mathrm{m.s.})}$} \\
\hline & & & & ( $\mu \mathrm{g} / 100 \mathrm{mg} \mathrm{m} . \mathrm{s})$. & \\
\hline $\begin{array}{l}\mathrm{K}_{1} \\
\mathrm{~K}_{1} \\
\mathrm{~K}_{1}\end{array}$ & & $\begin{array}{l}\text { Superior } \\
\text { Médio } \\
\text { Inferior }\end{array}$ & $\begin{array}{l}0,58 \\
0,51 \\
0,27\end{array}$ & $\begin{array}{l}136,90 \\
150,60 \\
243,00\end{array}$ & $\begin{array}{l}17,85 \\
19,86 \\
11,90\end{array}$ \\
\hline $\begin{array}{l}\mathrm{K}_{2} \\
\mathrm{~K}_{2} \\
\mathrm{~K}_{2}\end{array}$ & & $\begin{array}{l}\text { Superior } \\
\text { Médio } \\
\text { Inferior }\end{array}$ & $\begin{array}{l}0,67 \\
0,29 \\
0,59\end{array}$ & $\begin{array}{l}129,97 \\
140,33 \\
304,61\end{array}$ & $\begin{array}{l}17,27 \\
17,85 \\
16,11\end{array}$ \\
\hline $\begin{array}{l}K_{3} \\
K_{3} \\
K_{3}\end{array}$ & & $\begin{array}{l}\text { Superior } \\
\text { Médio } \\
\text { Inferior }\end{array}$ & $\begin{array}{l}0,25 \\
0,27 \\
0,45\end{array}$ & $\begin{array}{l}147,17 \\
150,59 \\
311,45\end{array}$ & $\begin{array}{l}10,16 \\
15,67 \\
11,32\end{array}$ \\
\hline$\Delta($ D.M.S. $)$ & $5 \%$ : & $\begin{array}{l}\text { (tratamentos) } \\
\text { (épocas) } \\
\text { (segmentos) }\end{array}$ & $\begin{array}{l}: 0,1289 \\
: 0,1261 \\
: 0,1294\end{array}$ & $\begin{array}{l}17,3083 \\
15,6335 \\
14,3642\end{array}$ & $\begin{array}{l}2,2330 \\
1,5961 \\
2,2189\end{array}$ \\
\hline Teste $\mathrm{F}$ : & & $\begin{array}{l}\text { (tratamentos) } \\
(\text { épocas) : } \\
\text { (segmentos): }\end{array}$ & $\begin{array}{l}1,63 \\
47,56 * * \\
118,71 * *\end{array}$ & $\begin{array}{c}9,83 * \\
5,60 * \\
425,47 * *\end{array}$ & $\begin{array}{c}1,60 \\
3,08 \\
11,86 * *\end{array}$ \\
\hline C.V. \%: & & $\begin{array}{l}\text { (tritamentos) } \\
\text { (épocas) } \\
\text { (segmentos) }\end{array}$ & $\begin{array}{l}: 6,49 \\
: 7,31 \\
: 8,19\end{array}$ & $\begin{array}{l}11,24 \\
11,68 \\
11,72\end{array}$ & $\begin{array}{l}16,91 \\
13,92 \\
21,13\end{array}$ \\
\hline
\end{tabular}

m.s. = matéria seca.

Significado dos símbolos - Ver Tabela 2. 
Tabela 8 - Teores de N-total, N- $\alpha \mathrm{NH}_{2}$ e Proteínas nos segmentos de parte aérea de plantas de cana-de-açūcar a os 40 dias após transplante para solução nutritiva conten do 3 concentraçoes de potássio.

\begin{tabular}{|c|c|c|c|c|}
\hline \multirow{2}{*}{$\begin{array}{l}\text { Trata- } \\
\text { mento }\end{array}$} & \multirow{2}{*}{$\begin{array}{l}\text { Segmento de } \\
\text { parte aérea }\end{array}$} & \multirow{2}{*}{$\frac{N-\text { total }}{(\%)}$} & $\mathrm{N}-\mathrm{aNH}_{2}$ & Proteína \\
\hline & & & $(\mu \mathrm{g} / 100 \mathrm{mg} \mathrm{m.s.})$ & (mg/100 mg m.s.) \\
\hline $\mathrm{K}_{1}$ & Superior & 0,43 & 130,06 & 16,11 \\
\hline $\mathrm{K}_{1}$ & Médio & 0,80 & 147,17 & 18,02 \\
\hline $\mathrm{K}_{1}$ & Inferior & 0,47 & 236,16 & 11,32 \\
\hline $\mathrm{K}_{2}$ & Superior & 0,65 & 154,02 & 19,42 \\
\hline $\mathrm{K}_{2}$ & Médio & 0,64 & 130,06 & 17,57 \\
\hline $\mathrm{K}_{2}$ & Inferior & 0,25 & 328,57 & 14,66 \\
\hline $\mathrm{K}_{3}$ & Supèrior & 0,42 & 143,81 & 13,92 \\
\hline $\mathrm{K}_{3}$ & Médio & 0,75 & 123,21 & 16,69 \\
\hline $\mathrm{K}_{3}$ & Inferior & 0,23 & 164,29 & 15,82 \\
\hline
\end{tabular}

Valores de D.M.S., Teste F e C.V. dos teores de $\mathrm{N}$-total, $\mathrm{N}-\alpha \mathrm{NH}_{2}$ e proteỉnas são apresentados na Tabela 7 . 
Tabela 9 - Teores de $\mathrm{N}-$ total, $\mathrm{N}-\alpha \mathrm{NH}_{2}$ e proteína nos segmentos de parte aérea de plantás de cana-de-açúcar aos 60 dias após o transplante para solução nutritiva contendo 3 concentrações de potássio.

\begin{tabular}{|c|c|c|c|c|}
\hline \multirow{2}{*}{$\begin{array}{l}\text { Trata- } \\
\text { mento }\end{array}$} & \multirow{2}{*}{$\begin{array}{l}\text { Segmento de } \\
\text { parte aérea }\end{array}$} & \multirow{2}{*}{$\frac{N-t o t a 1}{(\%)}$} & $\mathrm{N}-\alpha \mathrm{NH}_{2}$ & Proteina \\
\hline & & & $(\mathrm{g} / 100 \mathrm{mg} \mathrm{m} . \mathrm{s})$. & (mg/100 mg m.s.) \\
\hline $\begin{array}{l}K_{1} \\
K_{1} \\
K_{1}\end{array}$ & $\begin{array}{l}\text { Superior } \\
\text { Médio } \\
\text { Inferior. }\end{array}$ & $\begin{array}{l}0,36 \\
0,29 \\
0,14\end{array}$ & $\begin{array}{l}140,42 \\
120,93 \\
253,27\end{array}$ & $\begin{array}{l}10,16 \\
15,67 \\
11,32\end{array}$ \\
\hline $\begin{array}{l}\mathrm{K}_{2} \\
\mathrm{~K}_{2} \\
\mathrm{~K}_{2}\end{array}$ & $\begin{array}{l}\text { Superior } \\
\text { Médio } \\
\text { Inferior }\end{array}$ & $\begin{array}{l}0,34 \\
0,13 \\
0,14\end{array}$ & $\begin{array}{l}123,21 \\
116,37 \\
353,67\end{array}$ & $\begin{array}{l}20,76 \\
19,45 \\
11,61\end{array}$ \\
\hline $\begin{array}{l}\mathrm{K}_{3} \\
\mathrm{~K}_{3} \\
\mathrm{~K}_{3}\end{array}$ & $\begin{array}{l}\text { Superior } \\
\text { Médio } \\
\text { Inferior }\end{array}$ & $\begin{array}{l}0,26 \\
0,27 \\
0,09\end{array}$ & $\begin{array}{l}125,49 \\
116,37 \\
355,95\end{array}$ & $\begin{array}{l}15,53 \\
16,98 \\
14,51\end{array}$ \\
\hline
\end{tabular}

Vaiores de D.M.S., Teste F e C.V. dos teores de $\mathrm{N}-$ total, $\mathrm{N}-\alpha \mathrm{NH}_{2}$ e Proteínas são apresentados na Tabela 7 . 
Tabela 10 - Atividade de invertase ácida $(\mathrm{pH} 5,5)$ e invertase neutra ( $\mathrm{pH} 7,1)$ em extrato bruto de segmentos de par te aérea de plantas de cana-de-açúcar, aos $20,4 \overline{0}$ e 60 dias após o transplante para solução nutritiva contendo três concentrações de potássio.

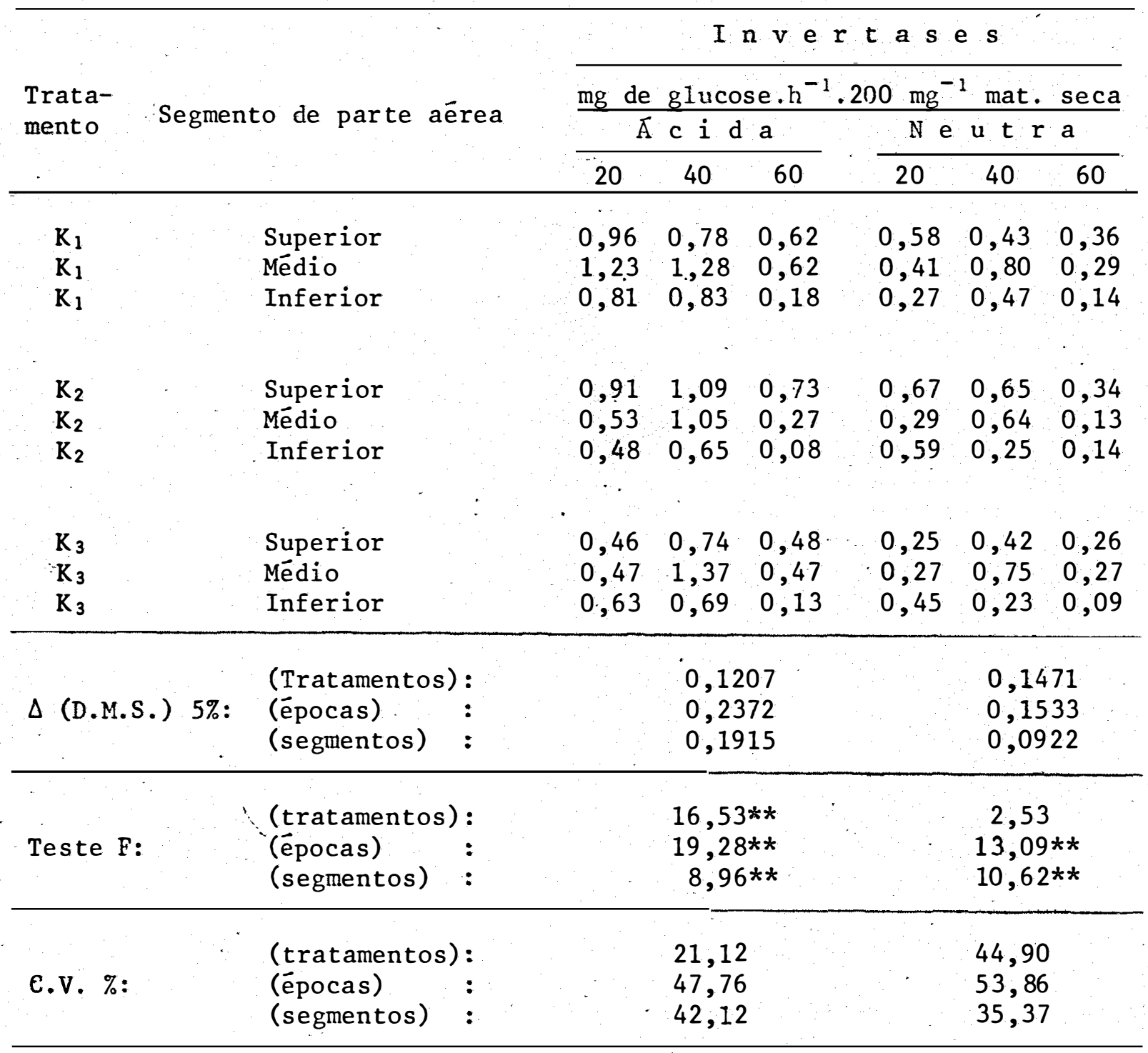

Significado dos simboloś - Ver Tabela 2. 